\title{
Federalism, the geographic location of groups, and conflict
}

\section{Working Paper}

Author(s):

Christin, Thomas; Hug, Simon

Publication date:

2006

Permanent link:

https://doi.org/10.3929/ethz-a-005389285

Rights / license:

In Copyright - Non-Commercial Use Permitted

Originally published in:

CIS working paper 23(2006) 


\section{uni | eth | zürich \\ Center for Comparative and International Studies (CIS) \\ No 23, 2006}

\section{Working Paper}

Published by the Center for Comparative and International Studies (ETH Zurich and University of Zurich)

\section{Federalism, the geographic location of groups, and conflict}

by Thomas Christin and Simon Hug

University of Zurich 


\title{
Federalism, the geographic location of groups, and conflict*
}

\author{
Thomas Christin ${ }^{\dagger}$ and Simon $\operatorname{Hug}^{\ddagger}$ \\ CIS, IPZ, Universität Zürich
}

\author{
Paper prepared for presentation at the \\ Annual Meeting of the American Political Science Association \\ Philadelphia, August 31 - September 3, 2006
}

August 16, 2006

\begin{abstract}
In the literature on civil conflicts federalism is often touted as a useful institution to address regional demands. Diversity in the groups present in a country is associated, however, also with a higher tendency for conflicts. In this paper we examine how the geographic distribution of groups across a country affects the ways in which federalism contributes to conflict resolution. Of tantamount importance in assessing these effects of federalism is whether particular types of distributions of groups across a territory makes the adoption of federal institutions more likely.
\end{abstract}

* This paper is related to the research project "Democratizing divided societies in bad neighborhoods," which is financed as part of the National Center for Competence in Research (NCCR) "Challenges to Democracy in the 21st Century" by the Swiss National Science Foundation. We thank Sunita Parikh for guiding us to badly needed data on India, and Jenna Bednar for helping us with the classification of federal countries.

$\dagger \quad$ Institut für Politikwissenschaft; Universität Zürich; Hirschengraben 56; 8001 Zürich; Switzerland; phone +41 (0)44 63450 91; fax: +41 (0)44634 50 98; email: christin@pwi.unizh.ch

$\ddagger \quad$ Institut für Politikwissenschaft; Universität Zürich; Hirschengraben 56; 8001 Zürich; Switzerland; phone +41 (0)44 63450 90/1; fax: +41 (0)44 63450 98; email: simon.hug@access.unizh.ch 


\section{Introduction}

Federalism and regional autonomy frequently appear among the proposed remedies for societal conflict (e.g., Nordlinger, 1972; Rabushka and Shepsle, 1972; Cohen, 1997; Congleton, 2000; Gurr, 2000; McGarry and OLeary, 2005). Such arrangements would grant disgruntled minorities at the national level autonomy to run their affairs at the regional level. As scholars of federalism have noted for some time, however, such arrangements are quite delicate (Riker, 1964; Lemco, 1991; Watts, 1998; Filippov, Ordeshook and Shvetsova, 2004; Bednar, 2006), and many federal systems have collapsed. Hence, recent research has focused more heavily on the question what types of federal arrangements are more conflict prone and what characteristics may make them more stable (e.g. Bunce, 2003a; Hale, 2004; Bakke and Wibbels, 2006; Brancati, 2006 (forthcoming)). At the center of this debate is the question whether ethnofederalism, i.e., a federal system where regional borders follow as closely as possible settlement patterns of minorities, is advisable or not.

Assessing whether particular makeups of federal units lead to more or less conflict is, however, a difficult endeavor. First of all, detailed information on the geographic location of ethnic groups and the composition of federal units is, especially in conflict-prone regions, difficult to come by. ${ }^{1}$ Second, the general makeup of the country is likely to influence the presence or absence of federalism and the type of federalism chosen. ${ }^{2}$ In this paper we do our best to address these problems, while assessing how the ethnic makeup of federal units affects the onset of civil wars.

In the next section we briefly review the literature on federalism, especially as it pertains to this institution's potential to mitigate societal conflicts. In section three we discuss and present data on the ethnic makeup of federal countries. Preliminary analyses presented in this section suggest that the ethnic makeup of countries affects the presence and type of federal arrangements. In section four we assess whether particular types of ethnic makeups make conflict onset more

\footnotetext{
${ }^{1}$ We completely eschew in this paper the problem that ethnic groups or any other groups are hardly given, but their definition is often part of ongoing conflict processes (e.g., Breton, 1964; Rabushka and Shepsle, 1972; Fearon and Laitin, 2000b).

${ }^{2}$ A nice little illustration to this effect appears in Glazer (1983), who shows that in the United States after 1789 new states were admitted to the Union only once WASPs formed a clear majority (see also McGarry and OLeary, 2005).
} 
likely in federal countries than in others. Section five concludes and charts future research.

\section{The debate on federalism}

Whether federalist arrangements or regional autonomy might prove an appropriate institutional means to mitigate societal conflicts is an increasingly hotly debated question. ${ }^{3}$ Gladly, this literature relies more and more often on the general literature on federal arrangements that highlights the latter's inherent instability (Riker, 1964; Lemco, 1991; Watts, 1998; Filippov, Ordeshook and Shvetsova, 2004; Bednar, 2006). When seeing the potential benefits of federal arrangements in this larger context, very quickly the question arises under what conditions federal arrangements are adopted. ${ }^{4}$ While there exist many case-based descriptive studies, systematic evidence, especially evidence obtained from theoretically guided research, is rare. Commonly it is assumed that large territories and/or populations or diverse populations make the adoption of a federal system more likely (Panizza, 1999). ${ }^{5}$

The idea that federalism is used to "hold together" diverse populations, or letting them "come together" (Stepan, 1999), is closely related to the notion of ethnofederalism. The debate over whether such federal systems, where federal borders follow closely settlement patterns of minorities, increase societal conflict or help mitigate it is a longstanding one in political science. Lipset $(1963,81)$ argues against federal units corresponding to the settlement of ethnic groups and is supported in this among others by Nordlinger (1972) (see also McGarry and OLeary, 2005). ${ }^{6}$ More recently Snyder $(2000,199 f f)$ very forcefully argued against ethnofederalism, especially in the light of the experiences after the fall of the iron

\footnotetext{
${ }^{3}$ We rely in this section heavily on the excellent reviews of the relevant literature in Sambanis and Milanovic (2004), Lake and Rothchild (2005), Sambanis (2005), and Bakke and Wibbels (2006), as well as several important points raised in McGarry and OLeary (2005). A much more partial review of the literature appears in Schou and Haug (2005).

${ }^{4}$ This problem of endogeneity of federal arrangements, which is already well problematized in Riker's (1964) incisive work (but since then often forgotten), makes the results discussed in the literature on the effects of federalism (e.g., Cohen, 1997; Saideman, Lanoue, Michael and Stanton, 2002) rather questionable (e.g., Christin and Hug, 2003, 2004, 2006).

${ }^{5}$ Elkins and Sides (2006) find similar results in an auxiliary regression.

${ }^{6}$ Ghai's (2002) work on autonomy and his case studies (Ghai, 2000) also relate to these arguments.
} 
curtain. ${ }^{7}$ His argument relies on the conception that ethnofederal arrangements were not forced on the communist regimes, but were used for strategic reasons by the communist leadership, and where they were adopted, a breakup was programmed. ${ }^{8}$ Related to this claim is Brancati's (2006 (forthcoming)) argument that regional parties are detrimental to the stability of federal systems. Obviously, ethnofederal systems are likely to create structures fostering the development of regional parties. ${ }^{9}$

More recently scholars have attempted to figure out under what conditions ethnofederal arrangements are more conflict prone. Hale (2004), for instance, suggests that the existence of a core ethnic region may lead to the collapse of states and/or civil war. ${ }^{10}$ Bakke and Wibbels (2006) look in their study of federal arrangements at fiscal decentralization, inequality, and the ethnic makeup of federal units and find interesting interaction effects when trying to explain conflicts. ${ }^{11}$ They find that ethnic heterogeneity when combined with high income inequality leads to more conflict, and that the effect of fiscal decentralization depends on the economic development of the ethnic regions.

While not directly addressing the question of types of federal arrangements, Sambanis and Milanovic's (2004) theory on the demand for sovereignty, ${ }^{12}$ and

\footnotetext{
${ }^{7}$ The experiences of the Soviet Union and the countries in its sphere of influence are discussed by a series of authors (e.g. Roeder, 1991; Cornell, 2002; Bunce, 2003a; Bunce, 2003b; Hale, 2006).

${ }^{8}$ This rather pessimistic assessment by Snyder (2000) is closely related to the notion that a peacefully functioning democracy requires an open and free "marketplace of ideas" (see also Mansfield and Snyder, 2005). In ethnofederalist countries, the "marketplace of ideas," however, is very likely to be segmented along ethnic lines.

${ }^{9}$ Brancati (2006 (forthcoming)) also suggests ways in which the emergence of regional parties may be hindered (see also Brancati, 2004).

${ }^{10}$ This point relates to Toft's (2003) claim that a group's geographic concentration and desire to control territory is closely linked to the outbreak of violence. Interestingly, Saideman, Lanoue, Michael and Stanton (2002) find that group concentration of "minorities at risk" affects positively both protest and rebellion. When separating low from high concentration groups, the authors find that federalism fails to have a statistically significant effect for low concentration groups, but that the negative effect on rebellion is statistically significant for high concentration groups (however this may in part be due to the different sample sizes instead of any substantive differences). Further down the line, Tir (2005) study on the effects of secession highlighting the higher likelihood of continuing violence after secessions that were violent, is instructive.

${ }^{11}$ Fiscal decentralization obviously relates more generally to the distribution of authority in federal countries, which is addressed in some contributions to Amoretti and Bermeo's (2003) volume.

${ }^{12}$ The reduced form of the theoretical argument is quite debatable, since other theoretical work on decentralization and secession offers much more fine-grained insights (e.g., Bolton and Roland, 1997; Young, 1998; Bordignon and Brusco, 2001; Alesina and Spolaore, 2003; Besley and Coate, 2003).
} 
their proposed empirical investigation suggests also a close relationship between the makeup of subnational units on demands for secession. ${ }^{13}$ Based on her work on the breakup of ethnofederal states in Central and Eastern Europe Bunce (2003b) suggests that nationalist mobilization failed to lead to conflict in all cases. Subsequently Bunce (2003a) proposes, derived from a comparison of a small number of cases, as explanation the bargaining style in ethnofederal states.

Clearly there are many arguments appearing in the literature whether and in what circumstances ethnofederal arrangements might work. ${ }^{14}$ Most obviously the ethnic composition of a country has to be considered, but also the endogenous nature of the federal arrangement. Before attempting to address these problems, we need to know, however, what we consider as federal arrangements.

\section{$3 \quad$ Federalism and the makeup of subunits}

When defining countries as federal scholars often refer to Riker's $(1964,11)$ rightly famous definition suggesting that "[a] constitution is federal if (1) two levels of government rule the same land and people, (2) each level has at least one area of action in which it is autonomous, and (3) there is some guarantee (even though merely a statement in the constitution) of the autonomy of each government in its own sphere." It is clear, however, that this definition is difficult to operationalize and thus it can hardly surprise that scholars often differ in their lists of federal countries. ${ }^{15}$ Bednar $(2006,21)$ convincingly argues that definitions relying both on structural features and "federal practices" are not very useful when attempting to assess the effect of federal arrangements. She pleads for a

\footnotetext{
${ }^{13}$ This is related to Saideman's (1998) work on secessionism and the study on irredentism by Saideman and Ayres (2000).

${ }^{14}$ What is missing, however, are theoretically sound explanations for when federal arrangements and what types of federal arrangements lead to conflict. Myerson (2006) theoretic assessment of federalism and democracy nationalism may offer interesting starting points as might (immodestly) the initial steps proposed in Hug (2005b).

${ }^{15}$ For our own amusement we depict in the appendix for a set of frequently used federal indicators how they evolve over time for countries considered to be federal at least for a period of time. The chosen indicators are the rather restrictive measure focusing on fiscal federalism provided by Henisz (2002), the typology provided by McGarry (2002), and the POLITY III indicator on centralization (Jaggers and Gurr, 1995). In future research we wish to look more closely at the dynamics of the introduction of federal arrangements, an avenue of research that Lake and Rothchild (2005) have started to explore.
} 
strictly structural definition with three necessary components, ${ }^{16}$ namely geopolitical division, independence, and direct governance. With the element geopolitical divisions she requires that territorial units are "constitutionally recognized and may not unilaterally abolished" and thus rules out nonterritorial arrangements as those advocated, for instance, by Bauer (1907). With independence it is assured that different levels of governments have "independent bases of authority," while direct governance assures that "each citizen is [directly] governed by at least two authorities." This clearcut and crisp definition allows to cut through the maze of different types of federal arrangements and competing lists of federal countries.

Based on these criteria, Bednar $(2006,26)$ identifies 26 entities having fulfilled all three of them at least for some time between 1990 and 2000 and thus can be classified as federal. The list of countries Bednar (2006) proposes comes very close to the list appearing in McGarry (2002). ${ }^{17}$ What McGarry $(2002,2005)$ provide in addition is a classification of the federal countries as national or multinational federations, ${ }^{18}$ as well as starting and end dates of the federal arrangements. We provide in table 1 the list of countries we consider federal. ${ }^{19}$

\footnotetext{
${ }^{16}$ We adopt here Goertz's (2006) advice to clearly determine whether components of a definition are necessary or sufficient elements for a concept.

${ }^{17}$ An article with an almost identical title is published (McGarry and OLeary, 2005), it fails to contain, however, the list of federal systems which we employ here.

${ }^{18}$ Unfortunately, these notions are nowhere clearly defined, but they come very close to the notion of ethnofederalism. Bunce (2003a), however, refers to Azerbaijan, Georgia, Russia, and Serbia-Montenegro as ethnofederalist states. Of these only the later two are considered by McGarry (2002) as multinational federations. Similarly, the POLITY III indicator (see appendix) classifies both Azerbaijan and Georgia as mixed regime (between unitary and federal), while Henisz (2002) codes this country as not federal. For Georgia Beck, Clarke, Groff, Keefer and Walsh (2001) also suggests that the subnational units fail to have sufficient authority (see appendix).

${ }^{19}$ An attractive feature of combining the lists of McGarry and OLeary (2005) and Bednar (2006) is that they both eliminate "quasi-federal" states like Spain, the Ukraine etc..
} 
Table 1: Federal countries

\begin{tabular}{|c|c|c|}
\hline \multirow[t]{2}{*}{ Country } & \multicolumn{2}{|c|}{ Bednar $(2006,26)^{a} \quad$ McGarry (2002) } \\
\hline & \multicolumn{2}{|c|}{ national federations } \\
\hline Argentina & - & $1853-$ \\
\hline Australia & - & 1901- \\
\hline Austria & - & 1920- \\
\hline Brazil & - & 1891- \\
\hline Germany & - & 1949- \\
\hline Mexico & - & $1917-$ \\
\hline Venezuela & - & $1960-$ \\
\hline United Arab Emirates & - & 1971- \\
\hline USA & - & 1789- \\
\hline & \multicolumn{2}{|c|}{ multinational federations } \\
\hline Belgium & 1994- & 1993- \\
\hline Bosnia & $1995-$ & 1995- \\
\hline Burma & & $1948-$ \\
\hline Cameroon & & $1961-1972$ \\
\hline Canada & - & $1867-$ \\
\hline Czechoslovakia & 1990-1992 & 1968-1992 \\
\hline Ethiopia & $1995-2000$ & $1992-$ \\
\hline India & - & $1950-$ \\
\hline Malaya & & $1957-1963$ \\
\hline Malaysia & - & 1963- \\
\hline Mali & & 1960 \\
\hline Micronesia & - & \\
\hline Nigeria & $1998-2000$ & $1960-$ \\
\hline Pakistan & 1990-1999 & $1947-1971$ \\
\hline Russia & $1992-2000$ & 1993- \\
\hline St. Kitts-Nevis & & 1983- \\
\hline South Africa & $1993-2000$ & $1996-$ \\
\hline Soviet Union & 1990-1991 & 1918-1991 \\
\hline Switzerland & - & 1848- \\
\hline West Indies Federation & & $1958-1962$ \\
\hline Yugoslavia (former) & 1990-1991 & 1953-1992 \\
\hline Yugoslavia & $1992-2000$ & 1992- \\
\hline
\end{tabular}

$a_{\text {- }}$ indicates that Bednar $(2006,26)$ considers the country as federal for the whole period between 1990 and 2000. We omit from her list the European Union, which she codes as federal for 1999-2000.

Table 1 lists these countries and adds two pieces of information. First we provide information on the time period for which Bednar $(2006,26)$ and McGarry (2002) consider these countries as federal. Second, from McGarry (2002) we also adopt the distinction between national and multinational federations. As table 1 illustrates there are very few contradictions between the two sets of authors. Omitting small differences in timing (e.g., Belgium becoming federal in 1993 or 
$1994^{20}$ ) the only contradictions concern Burma, St. Kitts-Nevis, and Micronesia. The first two countries are coded by McGarry (2002) as federal but are considered as quasi-federal, respectively unitary by Bednar $(2006,26)$, while for Micronesia the exact opposite is the case. ${ }^{21}$

The attractiveness of McGarry's (2002, 2005) distinction between national and multinational federations is that it is obviously closely related to the ethnic makeup of the countries concerned. Related notions are Alemán and Treisman's (2005) "ethnically mined" federations in which one group is a majority within one of the constituent units and a minority within the federation as a whole. ${ }^{22}$

Having at hand a list of federal countries a first question to address is what distinguishes these countries in terms of the overall ethnic makeup from other countries. $^{23}$ First, if we just consider the ethnic composition of federal and unitary states we find on the basis of Fearon's (2002) dataset that the ethnic fractionalization is practically identical in federal and unitary states, namely on average 0.485 compared to $0.476 .{ }^{24}$ When we distinguish between the two types of federations according to McGarry (2002) we find average ethnic fractionalization indices of 0.381 and 0.601 for the national and multinational federations. Despite the marked difference, and even when compared to the averages for unitary states, we fail to find a statistically significant relationship.

Slightly different is the result if we look at the overall number of groups per country as reported in Fearon's (2002) dataset. we find on average 5.144

\footnotetext{
${ }^{20}$ We also put in this category the rather large differences in timing when it comes to Nigeria and Pakistan. In the later case, Bednar $(2006,26)$ considers this country as federal between 1990 and 1999, while McGarry (2002) assume that the federal experience was limited to 19471971. We follow the latter coding decision, despite the fact that Alemán and Treisman's (2005) coding suggests that between 1971 and 1990 Pakistan was still federal.

${ }^{21}$ Griffiths and Nerenberg (2005) consider all these cases as federal, with the exception of Burma/Myanmar, while Watts (1996) excludes in addition Mirconesia. Given that none of our data on ethnic groups and "minorities at risk" nor the data on conflicts we use have Micronesia and St. Kitts-Nevis as observations, we will no longer consider these cases in the remainder of the paper. For Burma, however, we follow McGarry (2002) and consider it as a multinational federation.

${ }^{22}$ These authors consider nine countries to fall in this category, namely Belgium, Canada, Czechoslovakia, India, Nigeria, Pakistan, Soviet Union, Switzerland, Yugoslavia (former).

${ }^{23}$ Here, as well as in the subsequent analyses and the tables we present in the appendix we omit Micronesia, St. Kitts-Nevis, and the West Indies Federation. The reason is simply that these three states fail to appear in any of the conflict data we employ and also Fearon's (2002) data or the "minorities at risk" data (Gurr, 1993).

${ }^{24}$ With an F-statistic of 0.017 and one degree of freedom this difference is far from reaching statistical significance.
} 
Figure 1: Number of groups in different types of federations

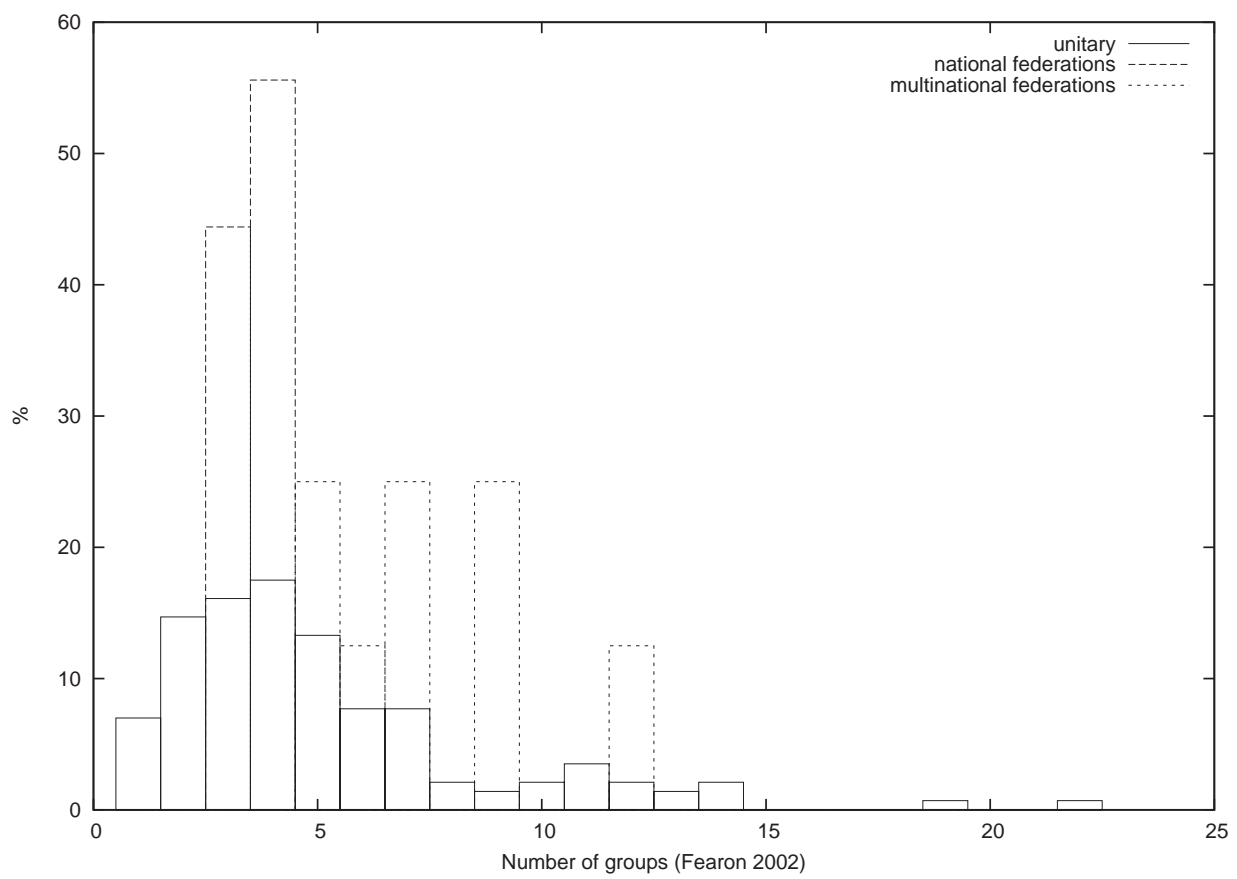

groups in the 160 countries he considers. When distinguishing between federal and non-federal countries we find hardly any differences. In federal states we find on average 5.412 groups, while this number is only slightly lower in unitary states, namely 5.112. ${ }^{25}$ When we distinguish, however, between the two types of federal systems, namely national and multinational, differences become more marked. In national federations we find 3.556 groups on average, while this number increases to 7.500 in multinational federations. ${ }^{26}$ These differences mask to some degree the distribution of the number of groups depicted in figure 1 . This figure suggests that unitary states have a very wide spectrum of numbers of groups, while national federations are very much concentrated on the left side of the graph, and, not surprisingly, multinational federations more on the right side of the graph. Interesting to note is, however, the pattern that the highest number of groups appear in unitary countries. ${ }^{27}$

\footnotetext{
${ }^{25}$ An F-Test (0.111, one degree of freedom) suggests that we cannot reject the null-hypothesis of equal means.

${ }^{26}$ This yields an F-statistic of 2.811 and a p-value of 0.063 .

${ }^{27}$ We find almost identical patterns when studying in what countries "minorities at risk" are
} 
Table 2: Group concentration and number of groups in federal countries ${ }^{a}$

\begin{tabular}{|c|c|c|c|c|c|c|}
\hline & \multicolumn{5}{|c|}{ Groupcon groups spatial distribution $^{b}$} & Fearon (2002) \\
\hline Country & \multicolumn{6}{|c|}{ national fedederations } \\
\hline Austria & - & - & - & - & 0 & 4 \\
\hline Australia & 1 & 0 & 0 & 0 & 1 & 3 \\
\hline Mexico & 1 & 0 & 2 & 0 & 3 & 4 \\
\hline Venezuela & 0 & 0 & 1 & 1 & 2 & 4 \\
\hline Brazil & 0 & 0 & 0 & 2 & 2 & 3 \\
\hline Argentina & 0 & 1 & 0 & 1 & 2 & 3 \\
\hline Germany & 0 & 1 & 0 & 0 & 1 & 3 \\
\hline \multirow[t]{2}{*}{ USA } & 2 & 0 & 1 & 1 & 4 & 4 \\
\hline & \multicolumn{6}{|c|}{ multinational federations } \\
\hline Belgium & - & - & - & - & 0 & 4 \\
\hline Bosnia & 0 & 1 & 1 & 1 & 3 & 3 \\
\hline Canada & 2 & 0 & 0 & 1 & 3 & 6 \\
\hline Czechoslovakia & 0 & 0 & 0 & 2 & 2 & 4 \\
\hline Ethiopia & 0 & 0 & 2 & 5 & 7 & 11 \\
\hline India & 1 & 1 & 3 & 5 & 10 & 12 \\
\hline Malaysia & 0 & 1 & 1 & 5 & 7 & 9 \\
\hline Mali & 1 & 1 & 0 & 2 & 4 & 5 \\
\hline Nigeria & 0 & 0 & 1 & 4 & 5 & 7 \\
\hline Russia & 2 & 2 & 6 & 17 & 27 & 5 \\
\hline South Africa & 2 & 1 & 2 & 3 & 8 & 13 \\
\hline Switzerland & 1 & 0 & 0 & 1 & 2 & 9 \\
\hline Yugoslavia & 1 & 0 & 4 & 3 & 8 & 7 \\
\hline
\end{tabular}

${ }^{a}$ Austria and Belgium have no "minorities at risk."

${ }^{b}$ The codes correspond to the following labels: 0 Widely dispersed; 1 Primarily urban or minority in one region; 2 Majority in one region, others dispersed; 3 Concentrated in one region.

As noted above, some authors claim that the concentration of groups in particular areas lead to higher probabilities of conflict outbreak in general (e.g., Toft, 2003) and more particularly in ethnofederal countries (Saideman, Lanoue, Michael and Stanton, 2002; Hale, 2004). For this reason we depict in table 2 for each federal country the information on group concentration as collected in the "minorities at risk" project (Gurr, 1993), ${ }^{28}$ as well as the number of groups

present (Christin and Hug, 2006). In $62.7 \%$ of all unitary countries "minorities at risk" are present, while this percentage increases to 88.9 in federal countries. In national federations the percentage is lower, namely at 77.8 , while it is equal to 100.0 in multinational federations. Interestingly enough, already the first difference between unitary and federal countries is statistically significant, as are the latter. Regarding the number of "minorities at risk" in federal countries table 2 shows the results.

${ }^{28}$ In the country tables we provide in the appendix we also indicate for all minorities at risk in the federal countries considered here their group concentration, as well as information on their relative group size stemming from Fearon (2002) and Elkins and Sides (2006). 
according to Fearon (2002). ${ }^{29}$ What is immediately transparent from this table is that in all multinational federations with "minorities at risk," some of the latter are concentrated in a region or form a majority in the region (codes 3 respectively 2 in table 2 . In national federations, however, having regionally concentrated "minorities at risk" is the exception, with Venezuela and Brazil being the exceptions to the rule. Hence, following Toft's (2003) argument we would expect multinational federations to be much more conflict-prone.

Taking this cursory evidence as indication that multinational federations (or ethnofederalism) is something to avoid, is, however, a step to far, at least for now. What many defenders of federal arrangements in general and multinational federations in particular argue is that even though multinational federations may lead to conflict or state collapse, the necessary counterfactual would be to look at what would have happened if the country had been federal (e.g., McGarry and OLeary, 2005). This obviously suggests (again) that federal arrangements are chosen in particular situations. Some very initial indications in this direction appear in table 3 . Using the set of countries and the number and sizes of groups reported in Fearon (2002) we propose a set of logit and multinomial logits to explain the presence of federal institutions. Given the data depicted in figure 1 and table 2 it fails to surprise that the number of groups cannot explain the presence of federal institutions. However, this same number has a positive effect on the presence of multinational federations and a negative one on national federations. Interestingly enough, the size of the largest group has no statistically significant effect in any of the models presented in table $3{ }^{30}$ Even though these analyses are very rough, they clearly suggest that analyzing the effect of federalism and types of federal arrangements has to proceed carefully.

\footnotetext{
${ }^{29}$ Fearon and Laitin $(2000 a)$ proposes an alternative measure for group concentration, which is used, for instance by Sambanis and Milanovic (2004). Since this data covers only 101 groups so far, we refrain from using it here. Similarly the MAR project proposes a new, more detailed coding of group concentration which we plan on using in future versions of this paper.

${ }^{30}$ Obviously work on polarization etc. would suggest using other functional forms for the postulated relationship. In the absence of any clear theoretical argument on which the functional form could be derived, we refrain from playing around with different specifications.
} 


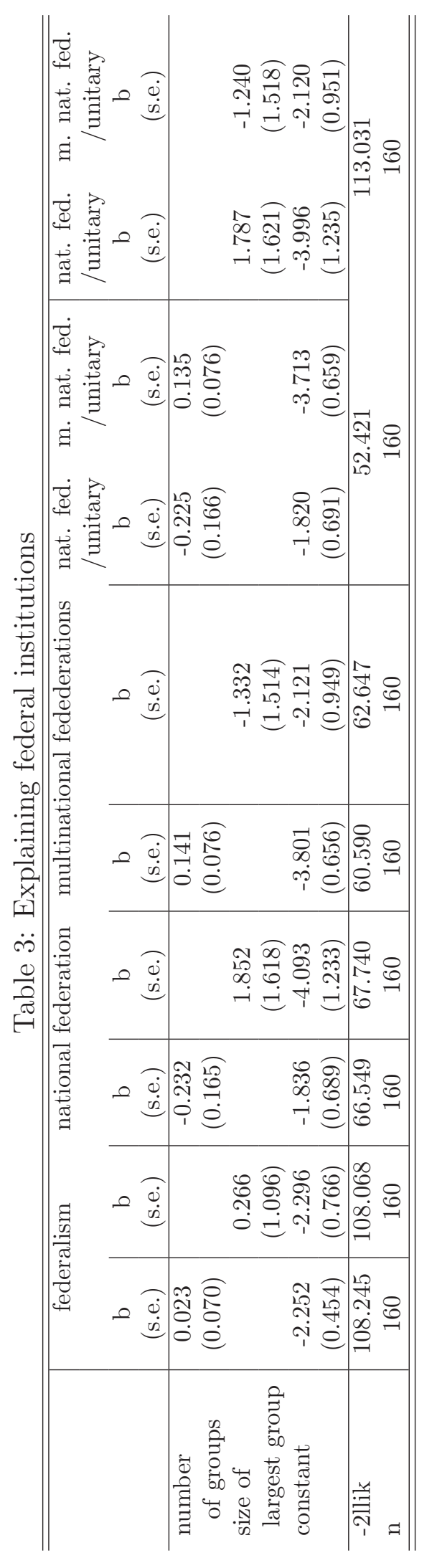




\section{Geographic location of groups and its effect on conflict}

Our hopefully sufficiently careful analysis on the effect of the ethnic makeup of federal countries starts off from Fearon and Laitin's (2003) analysis of the conditions leading to civil war, and we first analyze the effect of federal arrangements. ${ }^{31}$ In table 4 we report simple analyses which first replicate Fearon and Laitin's (2003) analysis on the basis of a logit and a probit model. In model 3 we add as additional indicator a federalism dummy, while in model 4 we make the distinction between national and multinational federalism. While in all cases the estimated coefficients for these additional variables are negative, meaning that in federal countries of whatever type conflict onset is less likely, the associated standard errors are so large that statistical significance is out of reach. Concerning the other estimated coefficients, these hardly change when the new variables are introduced.

Hence these analyses suggest that federal arrangements fail to affect the onset of conflict. ${ }^{32}$ Given this result we wish to assess whether among federal countries the configuration of the ethnic and political map affect their conflict-proness. ${ }^{33}$ To start with we first wish to assess whether limiting ourselves to federal countries affects the general thrust of Fearon and Laitin's (2003) results. The results reported in the first two columns in table 5 suggest that some effects lose their importance or significance or both. Whether the state is noncontiguous (ncontig), whether it exports a significant amount of oil (Oil), whether it is a new state, is

\footnotetext{
${ }^{31}$ We fully concur with the view articulated in Achen (2005) and Clarke (2005) that this is probably not the best strategy. The alternative, however, would be a fully specified theoretical model on the outbreak of civil wars. Such a model is, however, quite clearly still absent in this literature.

${ }^{32} \mathrm{We}$ consciously neglect here two possible problems which we have discussed elsewhere. First of all, given that measuring the onset of civil war is error-prone, the dependent variable is very likely to be affected by misclassification. As Christin and Hug (2004) and Hug (2005a) show, however, such misclassifications are likely to lead to biased estimates. Second, federal arrangements are likely to be endogenous in the model we wish to estimates. As we showed in Christin and Hug (2004) Christin and Hug (2006), addressing the problem of endogeneity may lead to substantively different estimated effects, particularly for the effect of political institutions.

${ }^{33}$ Hence, we proceed very similarly like Bakke and Wibbels (2006). As a consequence we are open to the same charge as they are, namely that we neglect the endogenous nature of federalism. In a later version we plan to address this shortcoming of our analysis.
} 
instable no longer affects the onset of civil war in a statistically significant way. ${ }^{34}$ For the other independent variables we find similar significant (or nonsignificant) effects. Interesting to note is especially the suddenly negative effect of religious frationalization, an effect which is positive in the analysis based on the whole set of countries.

Table 4: The effect of federalism on civil war onsset

\begin{tabular}{|c|c|c|c|c|c|c|}
\hline & $\begin{array}{c}\text { logit } \\
\text { b } \\
\text { (s.e.) }\end{array}$ & $\begin{array}{c}\text { probit } \\
\text { b } \\
\text { (s.e.) }\end{array}$ & $\begin{array}{c}\text { probit } \\
\text { b } \\
\text { (s.e.) }\end{array}$ & $\begin{array}{c}\text { probit } \\
\text { b } \\
\text { (s.e.) }\end{array}$ & $\begin{array}{c}\text { probit } \\
\text { b } \\
\text { (s.e.) }\end{array}$ & $\begin{array}{c}\text { probit } \\
\text { b } \\
\text { (s.e.) }\end{array}$ \\
\hline Prior war & $\begin{array}{l}-0.954 \\
(0.314)\end{array}$ & $\begin{array}{l}-0.391 \\
(0.130)\end{array}$ & $\begin{array}{l}-0.406 \\
(0.131)\end{array}$ & $\begin{array}{l}-0.395 \\
(0.130)\end{array}$ & $\begin{array}{c}-0.402 \\
(0.131)\end{array}$ & $\begin{array}{c}-0.406 \\
(0.131)\end{array}$ \\
\hline Per capita income $t-1$ & $\begin{array}{l}-0.344 \\
(0.072)\end{array}$ & $\begin{array}{l}-0.135 \\
(0.028)\end{array}$ & $\begin{array}{l}-0.128 \\
(0.028)\end{array}$ & $\begin{array}{l}-0.128 \\
(0.029)\end{array}$ & $\begin{array}{l}-0.135 \\
(0.028)\end{array}$ & $\begin{array}{c}-0.128 \\
(0.029)\end{array}$ \\
\hline $\log ($ population $)$ & $\begin{array}{c}0.263 \\
(0.073)\end{array}$ & $\begin{array}{c}0.108 \\
(0.031)\end{array}$ & $\begin{array}{c}0.126 \\
(0.033)\end{array}$ & $\begin{array}{c}0.112 \\
(0.032)\end{array}$ & $\begin{array}{c}0.120 \\
(0.033)\end{array}$ & $\begin{array}{c}0.126 \\
(0.033)\end{array}$ \\
\hline $\log ($ mountainous terrain $)$ & $\begin{array}{c}0.219 \\
(0.085)\end{array}$ & $\begin{array}{c}0.091 \\
(0.034)\end{array}$ & $\begin{array}{c}0.092 \\
(0.034)\end{array}$ & $\begin{array}{c}0.091 \\
(0.034)\end{array}$ & $\begin{array}{c}0.092 \\
(0.034)\end{array}$ & $\begin{array}{c}0.092 \\
(0.034)\end{array}$ \\
\hline Noncontiguous state & $\begin{array}{c}0.443 \\
(0.274)\end{array}$ & $\begin{array}{c}0.179 \\
(0.122)\end{array}$ & $\begin{array}{c}0.191 \\
(0.122)\end{array}$ & $\begin{array}{c}0.163 \\
(0.123)\end{array}$ & $\begin{array}{c}0.207 \\
(0.123)\end{array}$ & $\begin{array}{c}0.190 \\
(0.125)\end{array}$ \\
\hline Oil exporter & $\begin{array}{c}0.858 \\
(0.279)\end{array}$ & $\begin{array}{c}0.352 \\
(0.123)\end{array}$ & $\begin{array}{c}0.350 \\
(0.124)\end{array}$ & $\begin{array}{c}0.349 \\
(0.123)\end{array}$ & $\begin{array}{c}0.353 \\
(0.124)\end{array}$ & $\begin{array}{c}0.350 \\
(0.124)\end{array}$ \\
\hline New state & $\begin{array}{c}1.709 \\
(0.339)\end{array}$ & $\begin{array}{c}0.757 \\
(0.163)\end{array}$ & $\begin{array}{c}0.757 \\
(0.164)\end{array}$ & $\begin{array}{c}0.757 \\
(0.163)\end{array}$ & $\begin{array}{c}0.757 \\
(0.164)\end{array}$ & $\begin{array}{c}0.757 \\
(0.164)\end{array}$ \\
\hline Instability & $\begin{array}{c}0.618 \\
(0.235)\end{array}$ & $\begin{array}{c}0.259 \\
(0.101)\end{array}$ & $\begin{array}{c}0.260 \\
(0.101)\end{array}$ & $\begin{array}{c}0.261 \\
(0.101)\end{array}$ & $\begin{array}{c}0.259 \\
(0.101)\end{array}$ & $\begin{array}{c}0.260 \\
(0.101)\end{array}$ \\
\hline Democracy (Polity) & $\begin{array}{c}0.021 \\
(0.017)\end{array}$ & $\begin{array}{c}0.008 \\
(0.007)\end{array}$ & $\begin{array}{c}0.009 \\
(0.007)\end{array}$ & $\begin{array}{c}0.008 \\
(0.007)\end{array}$ & $\begin{array}{c}0.009 \\
(0.007)\end{array}$ & $\begin{array}{c}0.009 \\
(0.007)\end{array}$ \\
\hline Ethnic fractionalization & $\begin{array}{c}0.166 \\
(0.373)\end{array}$ & $\begin{array}{c}0.087 \\
(0.157)\end{array}$ & $\begin{array}{c}0.122 \\
(0.158)\end{array}$ & $\begin{array}{c}0.077 \\
(0.158)\end{array}$ & $\begin{array}{c}0.131 \\
(0.160)\end{array}$ & $\begin{array}{c}0.122 \\
(0.160)\end{array}$ \\
\hline Religious fractionalization & $\begin{array}{c}0.285 \\
(0.509)\end{array}$ & $\begin{array}{c}0.128 \\
(0.209)\end{array}$ & $\begin{array}{c}0.162 \\
(0.210)\end{array}$ & $\begin{array}{c}0.123 \\
(0.209)\end{array}$ & $\begin{array}{c}0.164 \\
(0.210)\end{array}$ & $\begin{array}{c}0.162 \\
(0.210)\end{array}$ \\
\hline Federalism & & & $\begin{array}{l}-0.223 \\
(0.145)\end{array}$ & $\begin{array}{l}-0.202 \\
(0.268)\end{array}$ & $\begin{array}{c}-0.212 \\
(0.165)\end{array}$ & \\
\hline National federation & & & & $\begin{array}{l}-0.202 \\
(0.268)\end{array}$ & & $\begin{array}{c}-0.227 \\
(0.268)\end{array}$ \\
\hline Multinational federation & & & & & $\begin{array}{l}-0.212 \\
(0.165)\end{array}$ & $\begin{array}{c}-0.222 \\
(0.165)\end{array}$ \\
\hline constant & $\begin{array}{l}-6.731 \\
(0.736)\end{array}$ & $\begin{array}{l}-3.224 \\
(0.303)\end{array}$ & $\begin{array}{l}-3.412 \\
(0.326)\end{array}$ & $\begin{array}{l}-3.264 \\
(0.307)\end{array}$ & $\begin{array}{l}-3.360 \\
(0.321)\end{array}$ & $\begin{array}{c}-3.412 \\
(0.326)\end{array}$ \\
\hline $\begin{array}{l}\text { Log likelihood } \\
\mathrm{N}\end{array}$ & $\begin{array}{c}-480.402 \\
6327\end{array}$ & $\begin{array}{c}-481.419 \\
6327\end{array}$ & $\begin{array}{c}-480.163 \\
6327\end{array}$ & $\begin{array}{c}-481.111 \\
6327\end{array}$ & $\begin{array}{c}-480.555 \\
6327\end{array}$ & $\begin{array}{c}-480.163 \\
6327\end{array}$ \\
\hline
\end{tabular}

Thus, we can turn to our main question, namely whether among federal coun-

\footnotetext{
${ }^{34}$ In part this is obviously due to the fact that the sample size cut to a sixth of the original size.
} 
tries settlement patterns and borders of the subnational units have an effect conflict onset. A very first and crude analysis relies on the indicator distinguishing between different types of federal systems. Given that we now only consider federal countries we only use the indicator for multinational federations as additional explanatory variable. The results for this model appear in column 3 of table 5 and suggest that multinational federations compared to national federations are more conflict-prone. Since we had noted above that the presence of multinational federations is closely related to the number of groups present in a country, we use both the number of groups reported in Fearon (2002) and the number of "minorities at risk" (Gurr, 1993) as independent variables. In both cases, but especially for the first variable, to find sizeable positive effects. While this already suggests the difficulty to assess the causal effect of particular federal arrangements and the geographic location of groups, we now turn to a more fine-grained analysis.

For these analyses we use a very simple indicator that takes account of the geographic location of groups, combined with the borders of federal units. We count the number of federal subunits in which the national majority group is not in a majority. ${ }^{35}$ This number of federal subunits inhabited more strongly by another group, we divide by the total number of federal units to obtain as indicator the proportion of such federal subunits.

When we consider the effect of the proportion of federal units dominated by national minorities (column 6 in table 5) we find a negative effect which fails to reach statistical significance. This result, together with the rather strong effects for the number of groups and our discussion of the possible endogeneity of federal institutions should make us suspicious, however. Clearly, whether there is a high proportion of federal units dominated by a national minority is very much a design question and is most likely heavily influenced by the ethnic makeup of the country.

\footnotetext{
${ }^{35}$ In both cases we use relative majority (i.e., plurality) as indicator.
} 


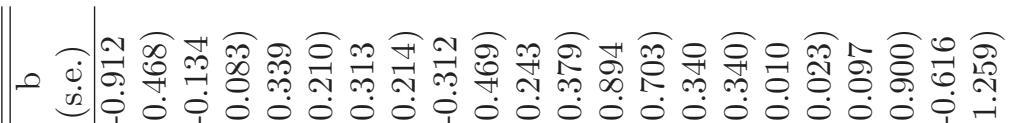

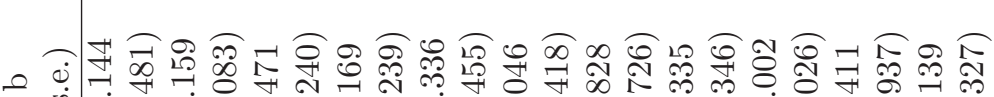

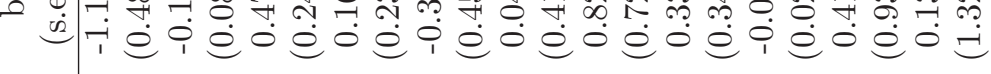

。

i)

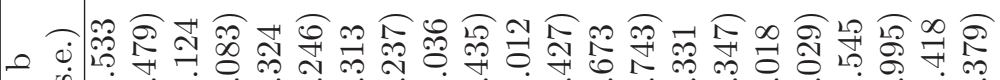

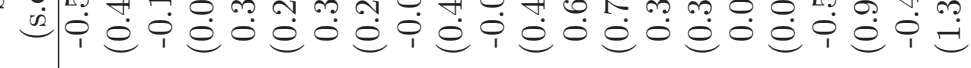

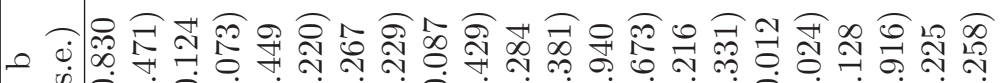

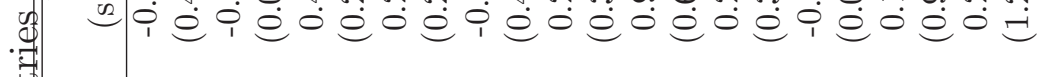

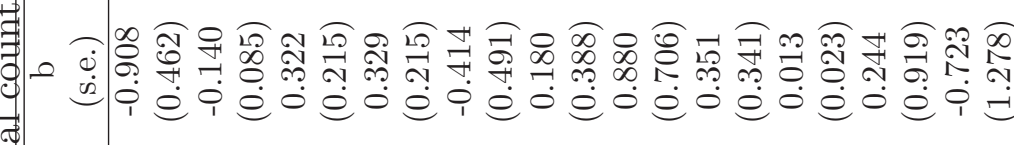

(n)

q

.

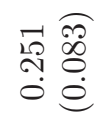

年

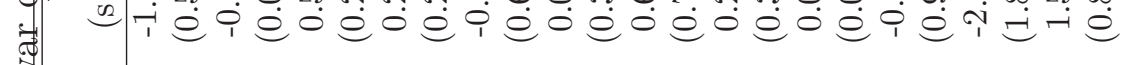

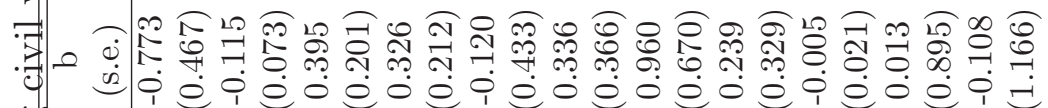

.

数

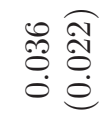

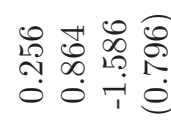

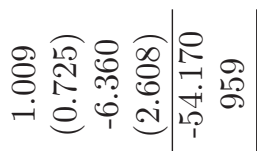

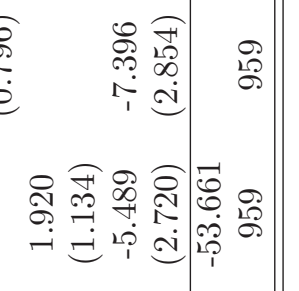

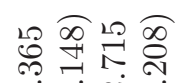

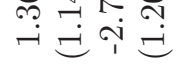

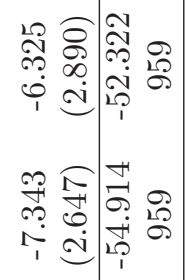

ํㅜㅇ

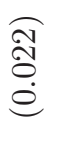

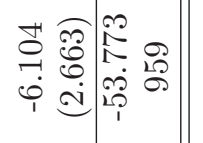

농

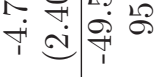

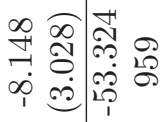

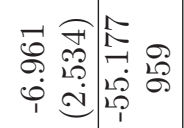

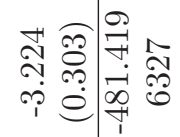

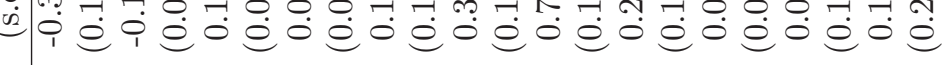


The results reported in table 6 clearly demonstrate this. If we use all the independent variables proposed by Fearon and Laitin $(2003)^{36}$ together with the number of ethnic groups, the number of "minorities at risk" and the number of federal units to explain the proportion of federal units dominated by a national minority we find an $r^{2}$ of 0.6. If we use only the latter variables, we still reach a respectable $r^{2}$ of 0.3 . Not surprisingly this variable is heavily affected by the ethnic configuration on the ground etc. Hence, the estimated effect for the proportion of federal units dominated by a national minority, as reported in table 5 (column 6) is very likely to be affected by endogeneity bias. A simple test of this consists of using as additional variable in the analysis the residuals from the regressions reported in table $6 .{ }^{37}$ In both cases (columns 7 and 9 in table 5) the effects are statistically significant. This suggests that the proportion of federal units dominated by a national minority is endogenous. To correct for this we use the predicted values of the regressions reported in table 6 to replace the affected variable. The results reported in columns 8 and 10 of table 5 suggest that when correcting for endogeneity the effect of the proportion of federal units dominated by national minorities increases statistically significantly the onset of civil wars.

\footnotetext{
${ }^{36}$ We add these variables to the regression following upon the argument by Acemoglu (2005), that on instrumental variables estimation, all exogenous variables should be included in the first stage regression. Obviously, even more important is to ensure that the instruments are truly exogenous and relate to the endogenous variables. We can show this latter point with the second regression, while the first one remains an argument, as in all instrumental variable estimations.

${ }^{37}$ This type of test for endogeneity relies on Hausman's (1978) work in the context of linear models, while Rivers and Vuong (1988) and Bollen, Guilkey and Mroz (1995) provide the derivations for nonlinear models.
} 
Table 6: Explaining the proportion of minority-majority federal units

\begin{tabular}{|c|c|c|}
\hline & $\begin{array}{c}\mathrm{b} \\
\text { (s.e.) }\end{array}$ & $\begin{array}{c}\mathrm{b} \\
\text { (s.e.) }\end{array}$ \\
\hline Prior war & $\begin{array}{l}-0.251 \\
(0.029)\end{array}$ & \\
\hline Per capita income $e_{t-1}$ & $\begin{array}{c}-0.014 \\
(0.001)\end{array}$ & \\
\hline $\log$ (population) & $\begin{array}{c}0.045 \\
(0.008)\end{array}$ & \\
\hline $\log ($ mountainous terrain) & $\begin{array}{l}-0.055 \\
(0.007)\end{array}$ & \\
\hline Noncontiguous state & $\begin{array}{l}-0.096 \\
(0.020)\end{array}$ & \\
\hline Oil exporter & $\begin{array}{c}0.008 \\
(0.022)\end{array}$ & \\
\hline New state & $\begin{array}{c}0.057 \\
(0.056)\end{array}$ & \\
\hline Instability & $\begin{array}{c}0.009 \\
(0.021)\end{array}$ & \\
\hline Democracy (Polity) & $\begin{array}{c}-0.008 \\
(0.001)\end{array}$ & \\
\hline Ethnic fractionalization & $\begin{array}{c}0.335 \\
(0.036)\end{array}$ & \\
\hline Religious fractionalization & $\begin{array}{c}0.177 \\
(0.047)\end{array}$ & \\
\hline Number of federal units & $\begin{array}{c}-0.001 \\
(0.001)\end{array}$ & $\begin{array}{c}-0.002 \\
(0.001)\end{array}$ \\
\hline Number of ethnic groups & $\begin{array}{c}0.010 \\
(0.004)\end{array}$ & $\begin{array}{c}0.008 \\
(0.003)\end{array}$ \\
\hline Number of "minorities at risk" & $\begin{array}{c}0.017 \\
(0.002)\end{array}$ & $\begin{array}{c}0.028 \\
(0.001)\end{array}$ \\
\hline constant & $\begin{array}{c}-0.229 \\
(0.085)\end{array}$ & $\begin{array}{c}0.148 \\
(0.020)\end{array}$ \\
\hline Root MSE & 0.188 & 0.322 \\
\hline$r^{2}$ & 0.650 & 0.320 \\
\hline $\mathrm{n}$ & 959 & 959 \\
\hline
\end{tabular}

\section{Conclusion}

If federal arrangements are chosen to allow diverse populations to "come together" or to be "held together," (Stepan, 1999) two things follow quite directly. First, the stability of federal arrangements and the latter's conflit-proness is likely to be related to the "ethnic map" of the country. Second, if trying to assess the effect of different federal arrangements like ethnofederalism and the like, we also need to consider what brought about these particular arrangements. 
In trying to offer elements pertaining to the first point, we have also tried to address the second point. Using very detailed information on the ethnic make up of federal countries we assessed through a rather crude indicator the effect of different types of ethnic makeups on civil war onset. Once we control for the endogenous nature of federal arrangements we find that larger shares of federal units dominated by a national minority increase the likelihood of civil war onset in federal countries.

This result has to be interpreted with quite some caution, and future research has to demonstrate its robustness. First of all, it would be useful to build into our empirical model more detailed information on the geographic location of groups. Group concentration, ethnic core regions etc. are all notions which we can measure with the data we have assembled and report on in the appendix. A more challenging endeavor would be to have more fine-grained information on the geographic location of groups by using Geographic Information Systems (GIS) data gleaned from the Atlas of Soviet geographers (Bruk, 1964) (see Cederman, Roed and Weidmann, 2006). But even with more and better data, the most daunting endeavor still seems to get a theoretical handle on the question why and possibly how and what type of federal arrangements might mitigate societal conflicts. 


\section{Appendix}

Below we report in detail for each country the type of data we collected to determine the makeup of federal units according to groups. The federal units were determined on the basis of information from the CIA World Factbook (https://www.cia.gov/cia/publications/factbook/geos/ (accessed July 21, 2006)) and the Administrative Divisions of Countries ("Statoids") (http://www.statoids.com/ accessed July 21, 2006)). To identify groups we relied on Fearon (2002) and the "minorities at risk" data (Gurr, 1993) as reported in Elkins and Sides (2006). For the group sizes we relied on data from European Values Study Group and Association (2006) as well as other surveys (as noted in the tables), which we also used to complement the list of groups if appropriate. When possible we use Census data at the level of the federal units. We first present in table ??, however, a summary of the information provided in the tables per country.

Table 7: Federations and Dominant Majorities or Minorities

\begin{tabular}{|c|c|c|c|c|c|}
\hline Federations & N Fed. Units & $\begin{array}{l}\mathrm{N} \text { Majo / } \\
\text { Mino States }\end{array}$ & $\begin{array}{l}\text { Nationwide Dominant } \\
\text { Group }\end{array}$ & $\begin{array}{l}\text { Majo. / Mino. Fed } \\
\text { unit }\end{array}$ & Majo. / Mino group \\
\hline \multicolumn{6}{|l|}{$\begin{array}{l}\text { National } \\
\text { tions }\end{array}$} \\
\hline \multicolumn{6}{|c|}{$\begin{array}{l}\text { Sources: http://www.indec.mecon.gov.ar/ Table: } 14.1 \text { Total de hogares y hogares donde al menos una persona se } \\
\text { reconoci perteneciente o descendiente de un pueblo indgena. Total del pais segun provincias }\end{array}$} \\
\hline $\begin{array}{l}\text { Australia } \\
\text { Sources: Census 2001: }\end{array}$ & $\begin{array}{l}8 \\
\text { ttp://www.abs. }\end{array}$ & $\begin{array}{l}0 \\
\text { v.au/websitedb }\end{array}$ & $\begin{array}{l}\text { Caucasian }(84 \% \\
92 \%) \\
\text { d3310114.nsf/home/Pre }\end{array}$ & $\begin{array}{l}- \\
\text { ous\%20Censuses:\%20Cen }\end{array}$ & us\%20data \\
\hline $\begin{array}{l}\text { Austria } \\
\text { Sources: Population Es }\end{array}$ & $\begin{array}{l}9 \\
\text { imations 2006: }\end{array}$ & 0 tp://www.stati & $\begin{array}{l}\text { Austrians }(90-93 \%) \\
\text { ik.at/fachbereich_03/bev }\end{array}$ & elkerung_tab8.shtml & - \\
\hline Brazil & 27 & 17 & White $(54-55 \%)$ & $\begin{array}{l}\text { Acre } \\
\text { Alagoas } \\
\text { Amap } \\
\text { Amazonas } \\
\text { Bahia } \\
\text { Cear } \\
\text { Maranho } \\
\text { Mato Grosso } \\
\text { Par } \\
\text { Paraba } \\
\text { Pernambuco } \\
\text { Piau } \\
\text { Rio Grande do Norte } \\
\text { Rondnia } \\
\text { Roraima } \\
\text { Sergipe } \\
\text { Tocantins }\end{array}$ & $\begin{array}{l}\text { Mulatto } \\
\text { Mulatto } \\
\text { Mulatto } \\
\text { Mulatto } \\
\text { Mulatto } \\
\text { Mulatto } \\
\text { Mulatto } \\
\text { Mulatto } \\
\text { Mulatto } \\
\text { Mulatto } \\
\text { Mulatto } \\
\text { Mulatto } \\
\text { Mulatto } \\
\text { Mulatto } \\
\text { Mulatto } \\
\text { Mulatto } \\
\text { Mulatto }\end{array}$ \\
\hline \multicolumn{6}{|c|}{ Sources: Census 2000: http://www.sidra.ibge.gov.br/ Table 136} \\
\hline $\begin{array}{l}\text { Germany } \\
\text { Sources: Estimations } 20\end{array}$ & 04 http://www. & $\begin{array}{l}0 \\
\text { atistik-portal.d }\end{array}$ & $\begin{array}{l}\text { Germans }(91 \%-95 \%) \\
\text { Statistik-Portal/de_jb01 }\end{array}$ & ahrtab2.asp & - \\
\hline Mexico & 32 & 0 & Mestizo (60\%) & $\begin{array}{l}\text { Oaxaca, Chiapas and } \\
\text { Yucatan }\end{array}$ & $\begin{array}{l}\text { Strong Indigenous Mi- } \\
\text { norities - }\end{array}$ \\
\hline \multicolumn{6}{|c|}{ http://www.inegi.gob.mx/est/contenidos/espanol/rutinas/ept.asp?t=mlen02\&c=3327; Library of Congress } \\
\hline \multicolumn{6}{|c|}{$\begin{array}{l}\text { Sources: Library of Congress: Foreign workers who represent about } 70 \% \text { are not included in the calculation since } \\
\text { they are not citizens of UAE. }\end{array}$} \\
\hline United States & 51 & 3 & White $(67 \%-82 \%)$ & $\begin{array}{l}\text { District of Columbia } \\
\text { Hawaii } \\
\text { New Mexico }\end{array}$ & $\begin{array}{l}\text { Black } \\
\text { Asian } \\
\text { Hispanics }\end{array}$ \\
\hline \multicolumn{6}{|c|}{$\begin{array}{l}\text { Sources: Population Division, U.S. Census Bureau: Annual Estimates of the Population by Race Alone and Hispanic } \\
\text { or Latino Origin for the United States and States: July 1, } 2004 \text { (SC-EST2004-04). The Census Bureau provides } \\
\text { statistics for non Hispanic or latino origins and Hispanic and latino origins. All "white" hispano have been classified } \\
\text { as hispanics. Other groups have been classified according to their group. E.g. Hispanics Asian alone have been } \\
\text { classified as Asian. }\end{array}$} \\
\hline Venezuela & 25 & 2 & Mestizo $(59 \%-68 \%)$ & $\begin{array}{l}\text { Delat Amacuro } \\
\text { Monagas }\end{array}$ & $\begin{array}{l}\text { White } \\
\text { White }\end{array}$ \\
\hline
\end{tabular}




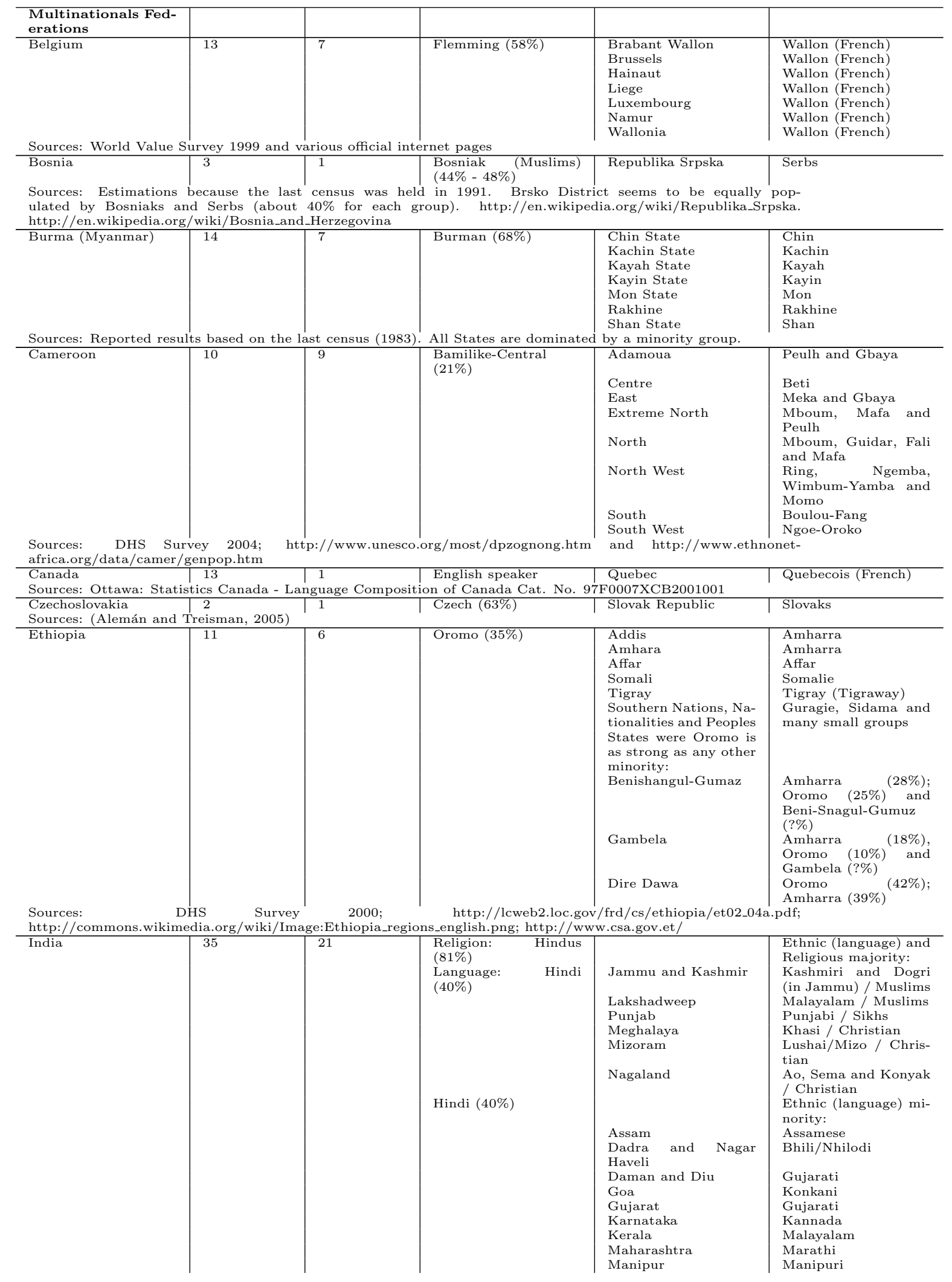




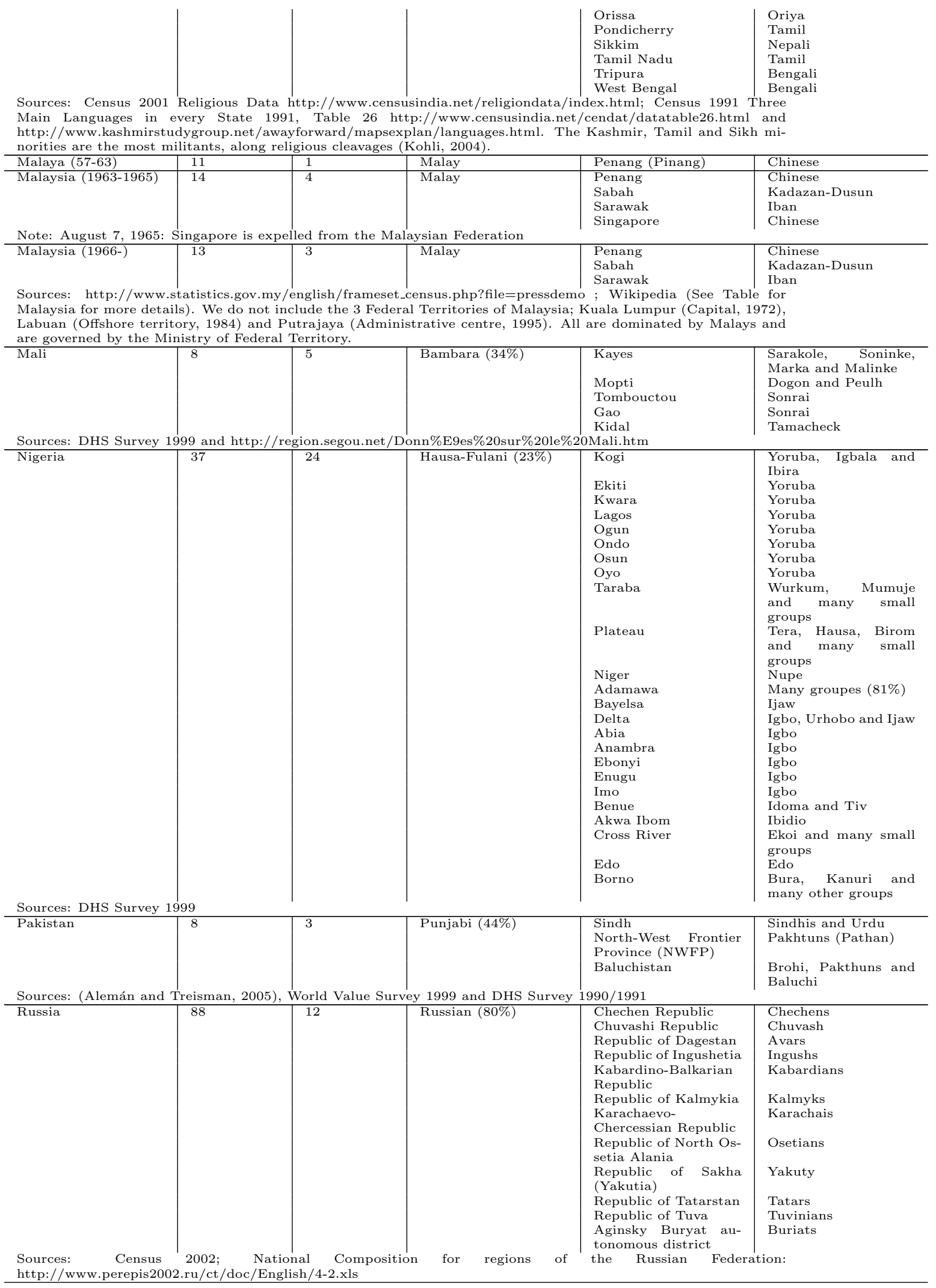




\begin{tabular}{|c|c|c|c|c|c|}
\hline South Africa & (2. & 2 & Black African (79\%) & $\begin{array}{l}\text { Northern Cape } \\
\text { Western Cape }\end{array}$ & $\begin{array}{l}\text { Coloured } \\
\text { Coloured }\end{array}$ \\
\hline \multicolumn{6}{|c|}{$\begin{array}{l}\text { Sources: South African Census } 2001 \text { by Province and Population group: http://www.statssa.gov.za/extract.htm ; } \\
\text { DHS Survey } 1998\end{array}$} \\
\hline Soviet Union & 15 & 14 & Russian (51\%) & $\begin{array}{l}\text { Armenian Republic } \\
\text { Azerbaydazhan Re- } \\
\text { public } \\
\text { Belorussian Republic } \\
\text { Estonian Republic } \\
\text { Georgian Republic } \\
\text { Kazakh Republic } \\
\text { Kirgiz Republic } \\
\text { Latvian Republic } \\
\text { Lithuanian Republic } \\
\text { Moldavian Republic } \\
\text { Tadzhik Republic } \\
\text { Turkmen Republic } \\
\text { Ukrainian Republic } \\
\text { Uzbek Republic }\end{array}$ & $\begin{array}{l}\text { Armenians } \\
\text { Azeris } \\
\text { Belarusans } \\
\text { Estonians } \\
\text { Georgians } \\
\text { Kazakhs } \\
\text { Kyrkyz } \\
\text { Latvians } \\
\text { Lithuanians } \\
\text { Moldavians } \\
\text { Tajiks } \\
\text { Turkmen } \\
\text { Ukrainians } \\
\text { Uzbeks }\end{array}$ \\
\hline \multicolumn{6}{|c|}{ Sources: Library of Congress } \\
\hline Switzerland & 26 & 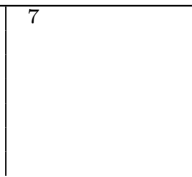 & German $(62 \%-65 \%)$ & $\begin{array}{l}\text { Fribourg } \\
\text { Geneva } \\
\text { Jura } \\
\text { Neuchatel } \\
\text { Tessin } \\
\text { Valais } \\
\text { Vaud }\end{array}$ & $\begin{array}{l}\text { Romand (French) } \\
\text { Romand (French) } \\
\text { Romand (French) } \\
\text { Romand (French) } \\
\text { Ticinese (Italian) } \\
\text { Romand (French) } \\
\text { Romand (French) }\end{array}$ \\
\hline Sources: Census 2000; h & ttp://www.bfs.ad & lmin.ch/bfs/porta & l/fr/index/themen/bevoe & kerung/sprachen__religion & n/blank/kennzahlen0/sprachen.html \\
\hline $\begin{array}{ll}\text { Former } & \text { Yugoslavia } \\
(1991) & \end{array}$ & 6 & 5 & Serbs $(36 \%, 1991)$ & $\begin{array}{l}\text { Bosnia-Herzegovina } \\
\text { Croatia } \\
\text { Macedonia } \\
\text { Montenegro } \\
\text { Slovenia }\end{array}$ & $\begin{array}{l}\text { Muslims (Bosniaks) } \\
\text { Croats } \\
\text { Macedonians } \\
\text { Montenegrins } \\
\text { Slovenes }\end{array}$ \\
\hline \multicolumn{6}{|c|}{ Sources: (Woodward, 1995); Table 2: pp 32-35. } \\
\hline $\begin{array}{l}\text { Yugoslavia (Serbia } \\
\text { and Montenegro) } \\
(1992-2006)\end{array}$ & 2 & 1 & Serbs & Montenegro & Montenegrins \\
\hline
\end{tabular}




\section{Country information}

Table 8: Argentina: National federation (1853-

\begin{tabular}{|c|c|c|c|}
\hline Fearon & white & Mestizo & Jews \\
\hline Fearon (2002) & 0.85 & 0.15 & 0.01 \\
\hline \multirow[t]{2}{*}{ Elkins and Sides $(2006)^{b}$} & & indigenous 0.01 & Jews 1.00 (wvs99: 0.70$)$ \\
\hline & $\mathrm{N}$ total of home & No of home with min. 1 pers. Indigenous & $\%$ \\
\hline Ciudad de Buenos Aires & 1'024'540 & $23^{\prime} 732$ & 2.3 \\
\hline Buenos Aires & 3'921'455 & $98^{\prime} 364$ & 2.5 \\
\hline Catamarca & $77^{\prime} 776$ & $1^{\prime} 962$ & 2.5 \\
\hline Chaco & $238^{\prime} 182$ & 8'640 & 3.6 \\
\hline Chubut & $114^{\prime} 725$ & $11^{\prime} 112$ & 9.7 \\
\hline Cordoba & $877^{\prime} 262$ & $18^{\prime} 380$ & 2.1 \\
\hline Corrientes & $225^{\prime} 957$ & $2^{\prime} 243$ & 1.0 \\
\hline Entre Rios & 316,715 & $4^{\prime} 643$ & 1.5 \\
\hline Formosa & $114 ’ 408$ & 6'123 & 5.4 \\
\hline Jujuy & $141 ' 631$ & $14 \cdot 935$ & 10.5 \\
\hline La Pampa & $91 ' 661$ & 3'444 & 3.8 \\
\hline La Rioja & $68 ' 390$ & $1 ' 429$ & 2.1 \\
\hline Mendoza & $410 ’ 418$ & $11^{\prime} 725$ & 2.9 \\
\hline Misiones & $235^{\prime} 004$ & 3'488 & 1.5 \\
\hline Neuquen & $128^{\prime} 351$ & $11^{\prime} 041$ & 8.6 \\
\hline Rio Negro & $154^{\prime} 453$ & $12 ' 164$ & 7.9 \\
\hline Salta & $241^{\prime} 407$ & $15^{\prime} 350$ & 6.4 \\
\hline San Juan & $148^{\prime} 902$ & $2 ' 198$ & 1.5 \\
\hline San Luis & $101^{\prime} 644$ & $2^{\prime} 282$ & 2.2 \\
\hline Santa Cruz & 53,834 & $2^{\prime} 625$ & 4.9 \\
\hline Santa Fe & $872 ’ 295$ & 16 '195 & 1.9 \\
\hline Santiago del Estero & $178^{\prime} 201$ & 2,549 & 1.4 \\
\hline Tierra del Fuego, Antartida e Islas del Atlantico Sur & 27,816 & $1 ’ 096$ & 3.9 \\
\hline Tucuman & $310^{\prime} 787$ & 6'239 & 2.0 \\
\hline Total & $10 ’ 075^{\prime} 814$ & $281 ’ 959$ & 2.8 \\
\hline
\end{tabular}

${ }^{a}$ Instituto Nacional de Estadistica y Censos de la Republica Argentina; http://www.indec.mecon.gov.ar/ Table: 14.1; Total of home with at least one Indigenous person

${ }^{b}$ While there are four WVS carried out in Argentina (1984, 1991, 1995, and 1999), information on ethnic groups was only collected in 1999, and in that survey no information is available on the regions to which individuals belong. 
Table 9: Australia National federation (1901-) Census 2001 ${ }^{a}$

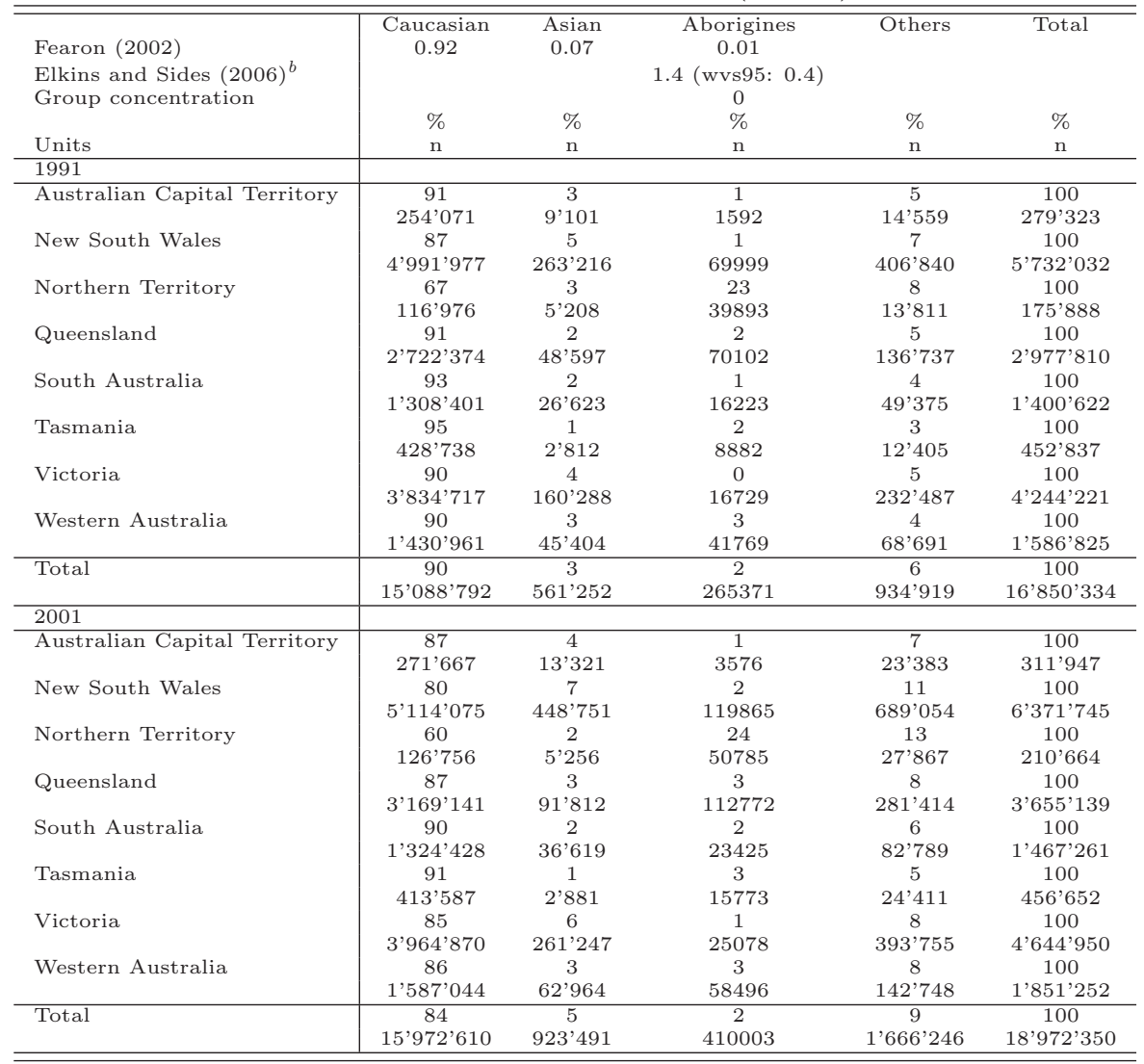

${ }^{a}$ Australian Bureau of Statistics; http://www.abs.gov.au/websitedbs/d3310114.nsf/home/ Previous\%20Censuses:\%20Census\%20data

${ }^{b}$ The WVS survey of 1995 also allows determining the ethnic makeup of the federal units and yields the same results for our measures. 
Table 10: Austria: National federation (1920-) Statistics $2005^{a}$

\begin{tabular}{|c|c|c|c|c|c|}
\hline \multirow{4}{*}{ Fearon $(2002)^{b}$} & $\begin{array}{c}\text { Austrians } \\
0.93\end{array}$ & $\begin{array}{c}\text { Former Yugoslavs } \\
0.04\end{array}$ & $\begin{array}{c}\text { Turks } \\
0.02\end{array}$ & $\begin{array}{c}\text { Croatians } \\
0.01\end{array}$ & \\
\hline & Austrians & Eu-14 & EU-10 & Not EU & Total \\
\hline & $\%$ & $\%$ & $\%$ & $\%$ & \\
\hline & $\mathrm{n}$ & $\mathrm{n}$ & $\mathrm{n}$ & $\mathrm{n}$ & $\mathrm{n}$ \\
\hline \multirow{2}{*}{ Burgenland } & 95.5 & 0.8 & 1.0 & 2.7 & 3.4 \\
\hline & $265^{\prime} 693$ & 2'159 & $2^{\prime} 886$ & $7^{\prime} 477$ & $278^{\prime} 215$ \\
\hline \multirow[t]{2}{*}{ Kaernten (Carinthia) } & 93.9 & 1.6 & 0.4 & 4.1 & 6.8 \\
\hline & $525^{\prime} 543$ & $9^{\prime} 224$ & $2^{\prime} 286$ & $22^{\prime} 838$ & $559^{\prime} 891$ \\
\hline \multirow{2}{*}{ Niederoesterreich } & 93.7 & 0.9 & 0.8 & 4.6 & 19.1 \\
\hline & 1'470'451 & $14^{\prime} 514$ & $12^{\prime} 936$ & $71^{\prime} 695$ & 1'569'596 \\
\hline \multirow[t]{2}{*}{ Oberoesterreich } & 92.6 & 1.1 & 0.4 & 5.9 & 17.0 \\
\hline & 1'293'405 & $15^{\prime} 387$ & $5^{\prime} 748$ & $81^{\prime} 688$ & 1'396'228 \\
\hline \multirow[t]{2}{*}{ Salzburg } & 87.7 & 2.9 & 0.5 & 8.9 & 6.4 \\
\hline & $461^{\prime} 177$ & $15^{\prime} 337$ & $2^{\prime} 577$ & $46^{\prime} 926$ & $526^{\prime} 017$ \\
\hline \multirow[t]{2}{*}{ Steiermark (Styria) } & 94.5 & 1.0 & 0.5 & 0.4 & 14.6 \\
\hline & 1'131'766 & $11^{\prime} 628$ & 6’013 & $4^{\prime} 812$ & 1'197'527 \\
\hline \multirow[t]{2}{*}{ Tirol } & 90.0 & 0.4 & 0.4 & 6.0 & 8.4 \\
\hline & $622^{\prime} 473$ & $2^{\prime} 482$ & $2^{\prime} 974$ & $41^{\prime} 516$ & $691^{\prime} 783$ \\
\hline \multirow[t]{2}{*}{ Vorarlberg } & 87.1 & 2.9 & 0.4 & 9.6 & 4.4 \\
\hline & $314^{\prime} 323$ & $10^{\prime} 416$ & $1^{\prime} 522$ & $34^{\prime} 566$ & $360 ' 827$ \\
\hline \multirow[t]{2}{*}{ Wien (Vienna) } & 82.0 & 2.1 & 0.2 & 14.0 & 19.8 \\
\hline & 1'333'084 & $34^{\prime} 178$ & 3'211 & $227^{\prime} 068$ & $1^{\prime} 626^{\prime} 440$ \\
\hline \multirow[t]{2}{*}{ Total } & 90.4 & 1.7 & 0.8 & 7.1 & 100.0 \\
\hline & $7^{\prime} 417^{\prime} 915$ & $137^{\prime} 663$ & $69^{\prime} 052$ & $581^{\prime} 894$ & $8^{\prime} 206^{\prime} 524$ \\
\hline
\end{tabular}

${ }^{a}$ Statistik Austria: http://www.statistik.at/fachbereich_03/bevoelkerung_tab8.shtml

${ }^{b}$ While there are two WVS carried out in Austria (1990 and 1997), no information on ethnic origins or language is available for the respondents. Similarly, there are no "minorities at risk."

Table 11: Belgium: Multinational Federation (1993 -) (WVS 1999)

\begin{tabular}{|c|c|c|c|c|c|}
\hline Fearon $(2002)^{a}$ & $\begin{array}{c}\text { Flemming } \\
0.6 \\
\%\end{array}$ & $\begin{array}{c}\text { Walloon } \\
0.31 \\
\%\end{array}$ & $\begin{array}{c}\text { Italians } \\
0.0 \\
\%\end{array}$ & $\begin{array}{c}\text { Moroccans } \\
0.01 \\
\%\end{array}$ & $\begin{array}{r}\text { Total } \\
\%\end{array}$ \\
\hline Units & $\mathrm{n}$ & $\mathrm{n}$ & $\mathrm{n}$ & & $\mathrm{n}$ \\
\hline \multirow{2}{*}{ Antwerpen } & 100 & 0 & & & 100 \\
\hline & 242 & 0 & & & 242 \\
\hline \multirow{2}{*}{ Brabant Wallon } & 0 & 100 & & & 100 \\
\hline & 0 & 46 & & & 46 \\
\hline \multirow[t]{2}{*}{ Brussels* (Bruxelles) } & 2.4 & 97.6 & & & 100 \\
\hline & 12 & 485 & & & 497 \\
\hline Flanders*b & $>50 \%$ & & & & \\
\hline Hainaut & & $>50 \%$ & & & \\
\hline \multirow[t]{2}{*}{ Liege } & 0 & 100 & & & 100 \\
\hline & 0 & 177 & & & 177 \\
\hline \multirow[t]{2}{*}{ Limburg } & 100 & 0 & & & 100 \\
\hline & 102 & 0 & & & 102 \\
\hline \multirow{2}{*}{ Luxembourg } & 0 & 100 & & & 100 \\
\hline & 0 & 44 & & & 44 \\
\hline \multirow{2}{*}{ Namur } & 0 & 100 & & & 100 \\
\hline & 0 & 61 & & & 61 \\
\hline \multirow{2}{*}{ Oost-Vlaanderen } & 100 & 0 & & & 100 \\
\hline & 209 & 0 & & & 209 \\
\hline \multirow[t]{2}{*}{ Vlaams-Brabant } & 100 & 0 & & & 100 \\
\hline & 104 & 0 & & & 104 \\
\hline Wallonia* & & $>50 \%$ & & & \\
\hline \multirow[t]{2}{*}{ West-Vlaanderen } & 100 & 0 & & & 100 \\
\hline & 164 & 0 & & & 164 \\
\hline \multirow{2}{*}{ Total } & 43.6 & 56.4 & & & 100 \\
\hline & 833 & 1079 & & & 1912 \\
\hline
\end{tabular}

${ }^{a}$ There are no "minorities at risk" in Belgium.

${ }^{b}$ Reported results for Flanders, Hainant and Wallonia are basic estimations of the dominant group. 


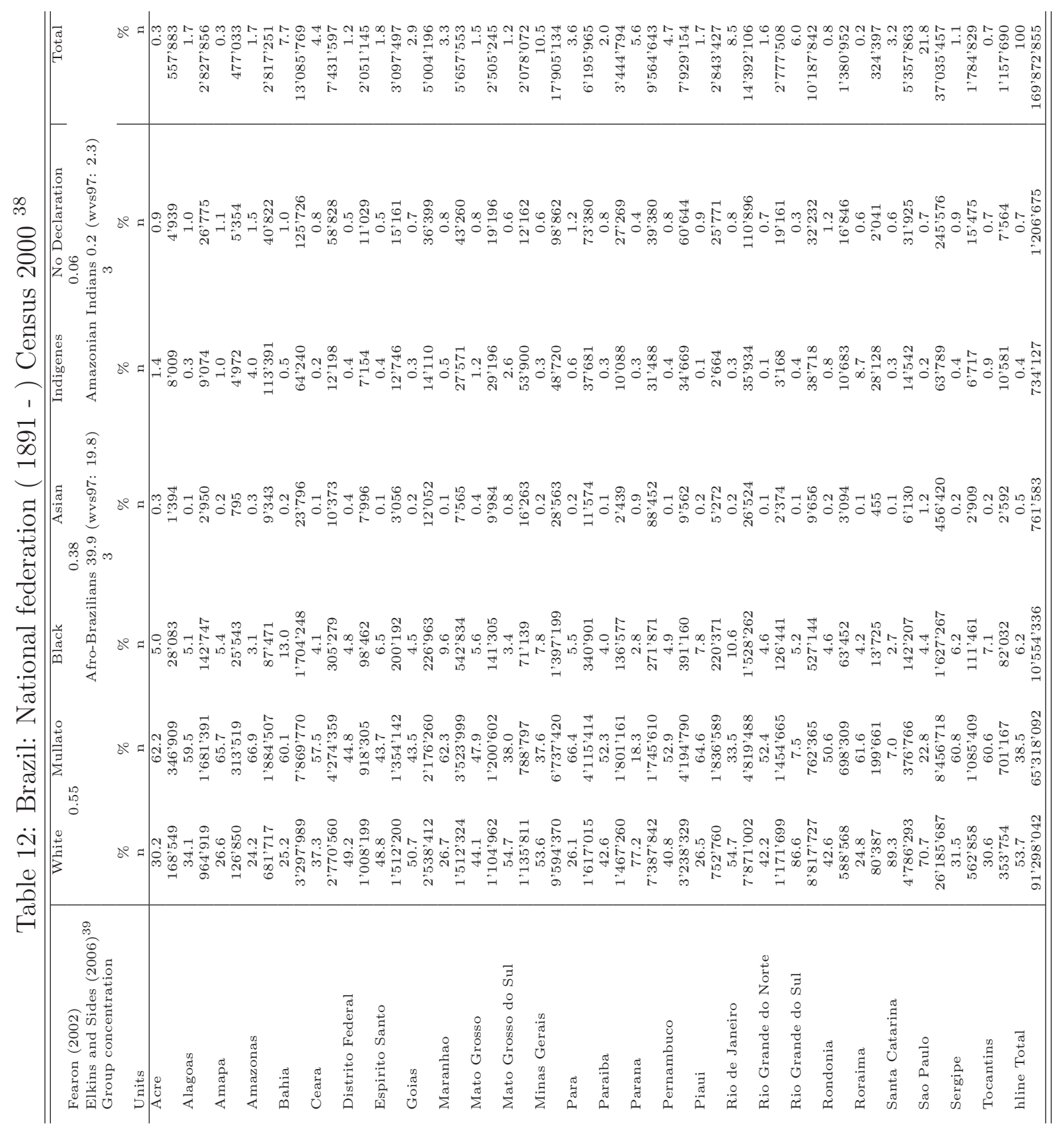


Table 13: Bosnia: Multinational Federations(1995 - $)^{a}$

\begin{tabular}{|c|c|c|c|c|c|c|}
\hline & Muslims & Bosniaks (SERBS) & Croats & other & & Total \\
\hline Fearon (2002) & 0.44 & 0.31 & 0.17 & & & \\
\hline Elkins and Sides $(2006)^{b}$ & $38.0($ wvs01:40.4) & $40.0($ wvs01: 43.7) & $22.0($ wvs01: 15.5) & & & \\
\hline Group concentration & 1 & 2 & 3 & & & \\
\hline Units & $\%$ & $\%$ & $\%$ & $\%$ & $\%$ & $\mathrm{n}$ \\
\hline Brcko district (Brcko Distrikt)* & 40 & 40 & 20 & & 2 & 87000 \\
\hline Federacija Bosna i Hercegovina & 80 & 14 & 4 & & 63 & $2^{\prime} 5000^{\prime} 000$ \\
\hline Republika Srpska & 10 & 88 & 1 & & 35 & $1^{\prime} 411^{\prime} 000$ \\
\hline Total & 48 & 37 & 14 & & 100 & $4^{\prime} 0000^{\prime} 000$ \\
\hline
\end{tabular}

${ }^{a}$ Estimations found on CIA Factbook and Wikipedia

${ }^{b}$ Both the WVS of 1995 and of 2001 also allow for estimating the ethnic make-up of the federal units and yield similar results. 


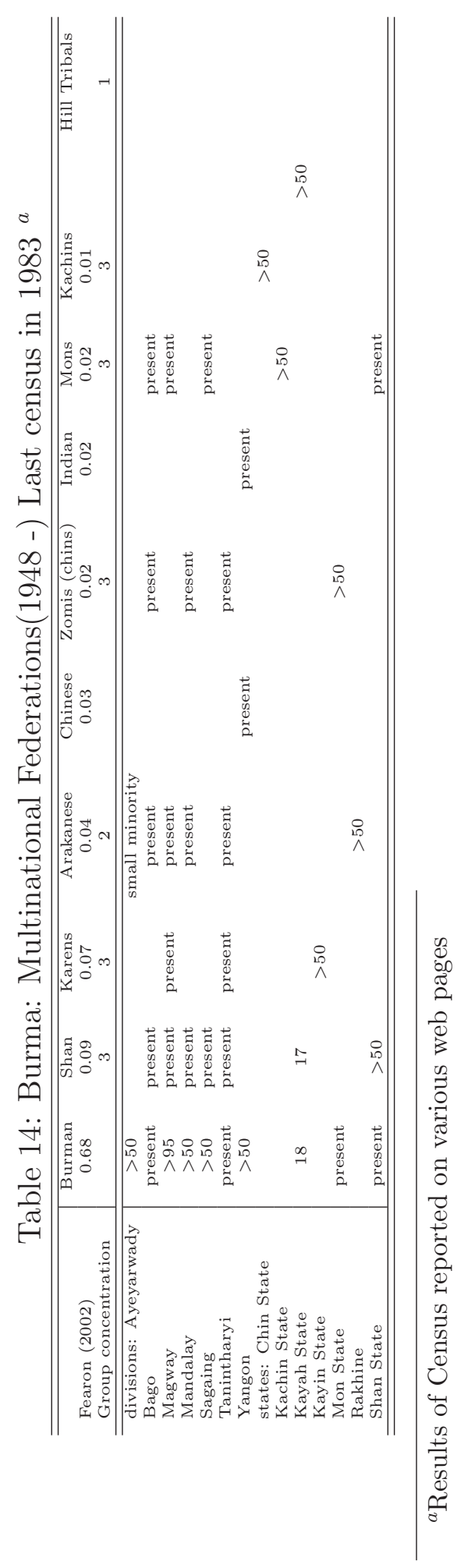




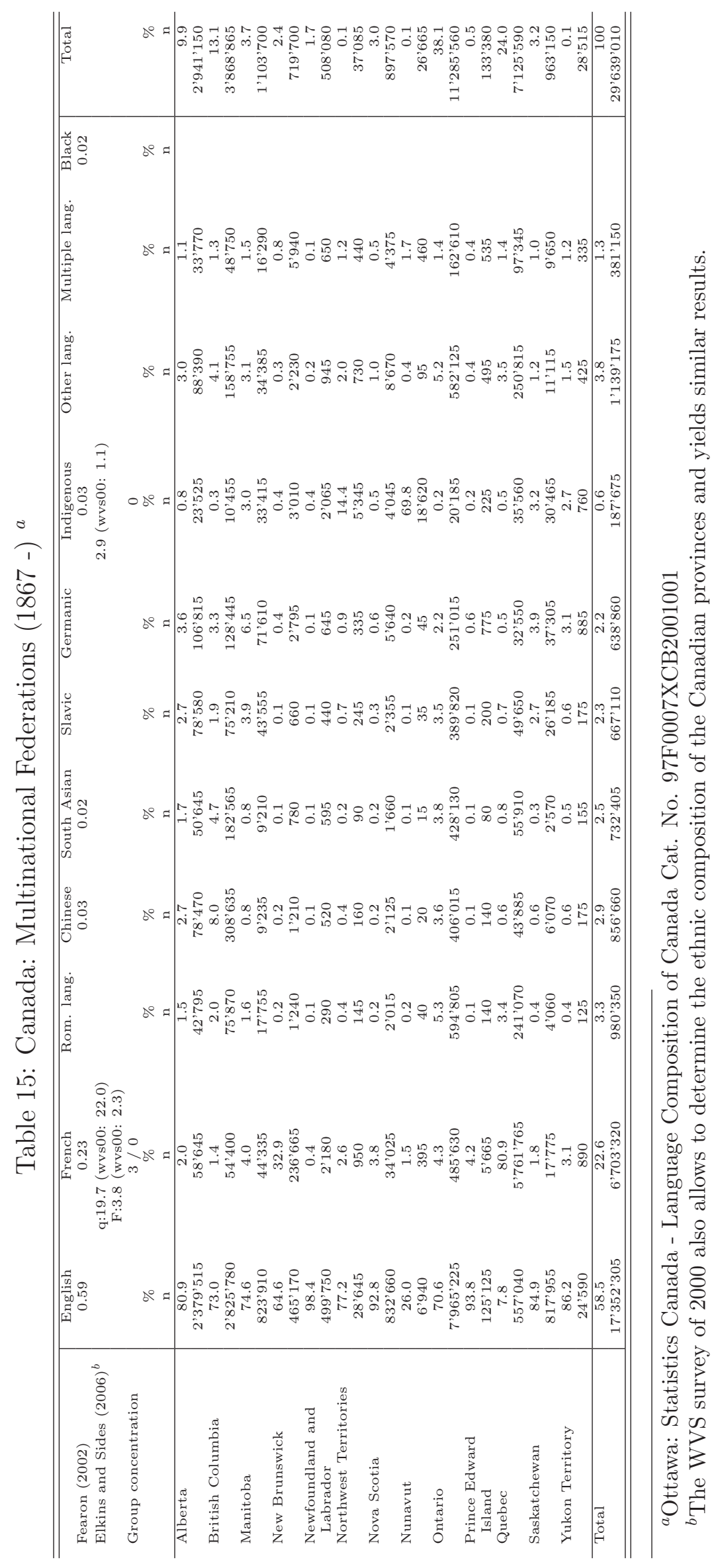




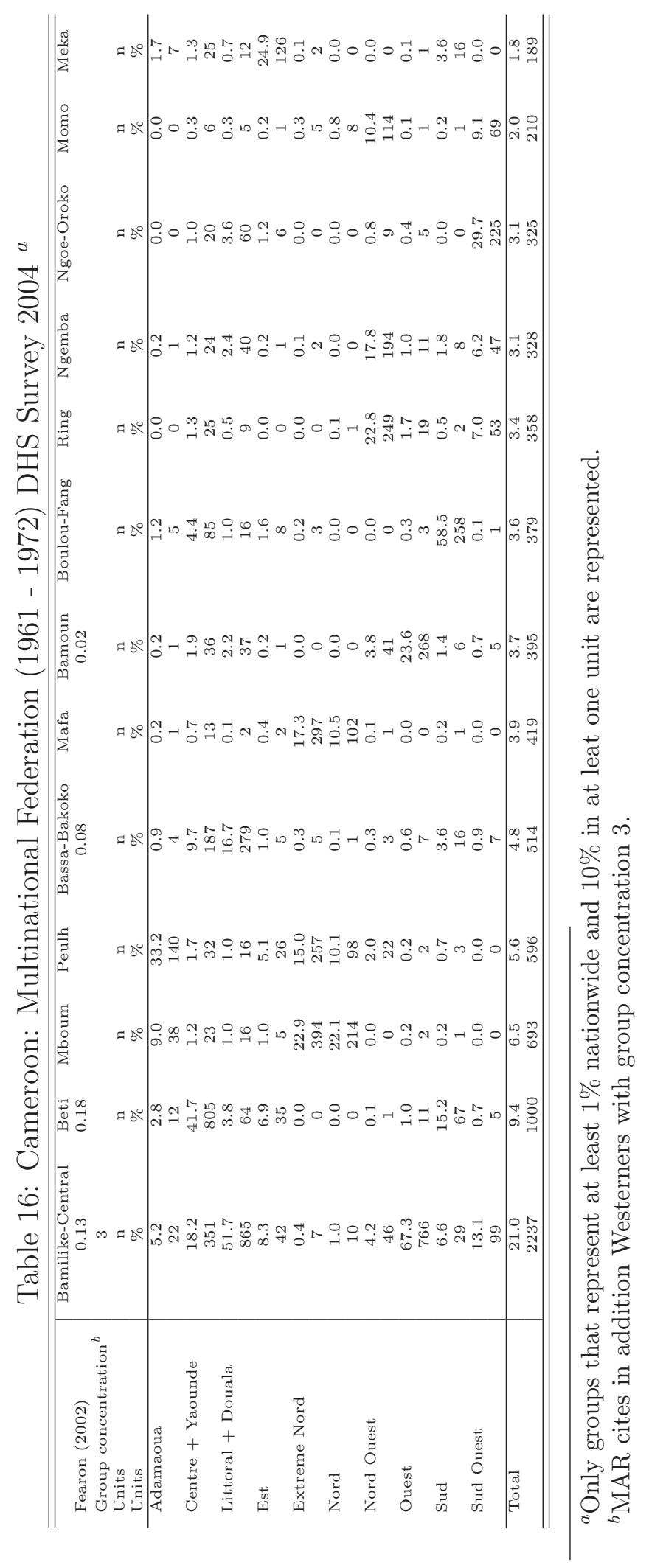




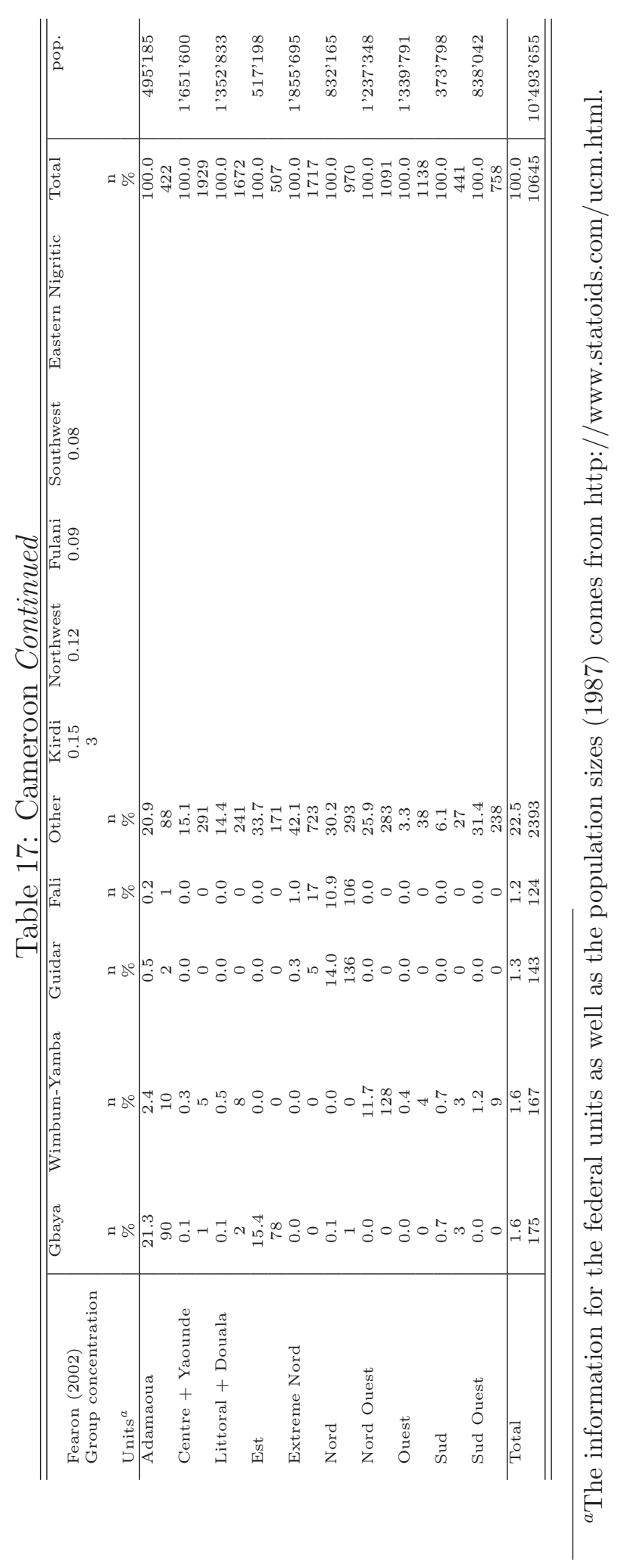


Table 18: Czechoslovakia: Multinational Federation (1968 - 1992)

\begin{tabular}{|c|c|c|c|c|c|c|c|c|}
\hline \multirow{3}{*}{$\begin{array}{l}\text { Fearon }(2002) \\
\text { Group concentration }^{a} \\
\text { Units }^{b}\end{array}$} & \multicolumn{2}{|c|}{ Czech } & \multicolumn{2}{|c|}{ Slovak } & \multicolumn{2}{|c|}{ Hungarians } & \multicolumn{2}{|c|}{ Roma } \\
\hline & 0.63 & & & & & & & \\
\hline & $\%$ & (n) & $\%$ & (n) & $\%$ & (n) & $\%$ & (n) \\
\hline $\begin{array}{l}\text { Czech Republic } \\
\text { Slovak Republic }\end{array}$ & Majority & Majori & & & & & & \\
\hline
\end{tabular}

${ }^{a}$ These group concentration indices come from the Czech Republic (Slovaks, Roma) and Slovakia (Hungarians, Roma).

${ }^{b}$ While there were separate WVS carried out in the Czech Republic and Slovakia, none contained information on the language. However, it would be possible to get information on the proportion of Gypsys. 


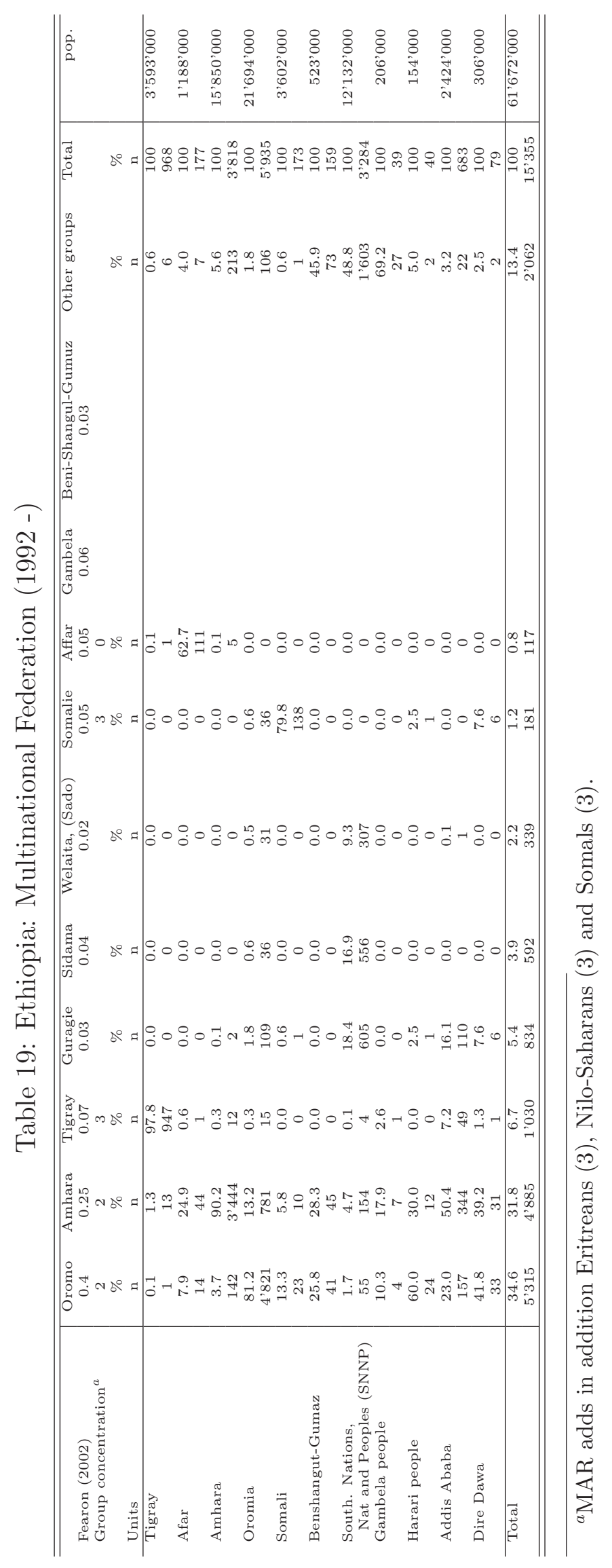


Table 20: Germany: National federation $\left(1949\right.$ - ) Statistics $2004^{a}$

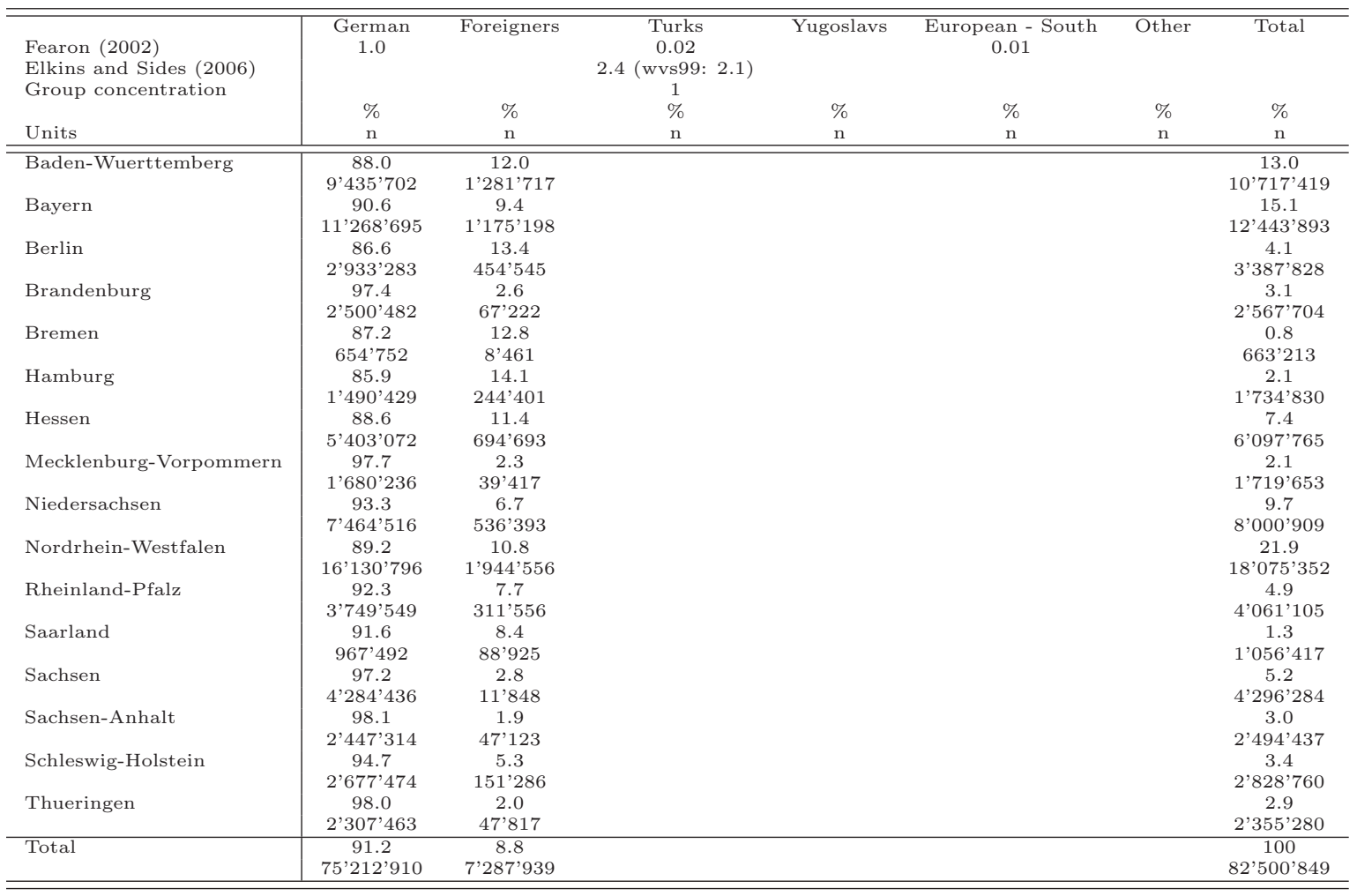

${ }^{a}$ Estimations 2004 http://www.statistik-portal.de/Statistik-Portal/de_jb01_jahrtab2.asp 
Table 21: India: Multinational Federation (1950 -) Census 1991 and $2001^{a}$

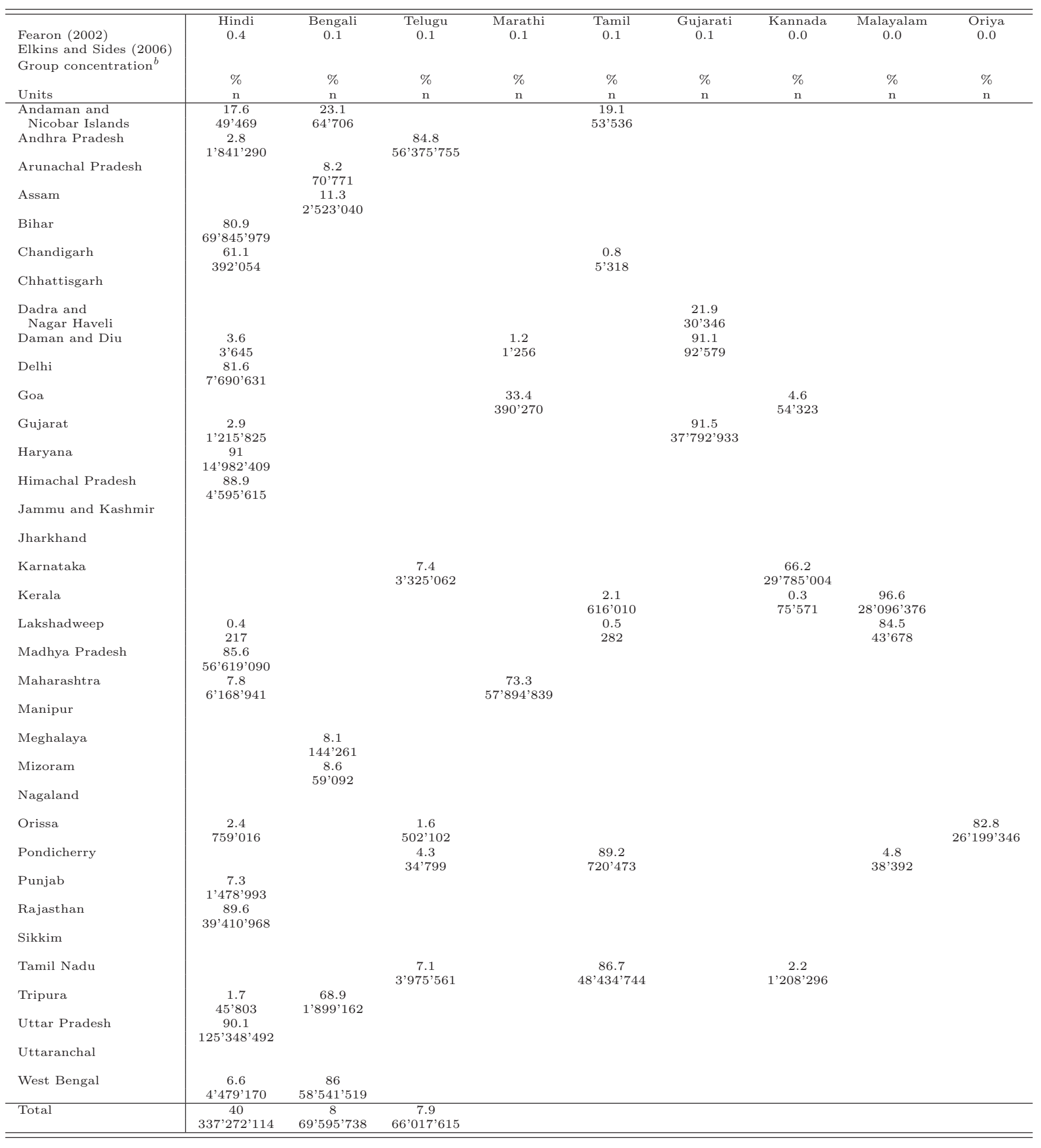

${ }^{a}$ Main languages 1991 or religion 2001 in each State;

http://www.censusindia.net/cendat/datatable26.html; http://www.censusindia.net/religiondata/Religiondata_2001.x The religion data have been used for the Sikhs, Muslims and Christians. The groups are not exclusive.

${ }^{b}$ MAR adds Nagas 0.3 (3), Santals 0.7 (1),3̧ 3 cheduled Tribes 7.5 (wvs01:5.0) (2) 
Table 22: India: Multinational Federation (1950 -) Continued

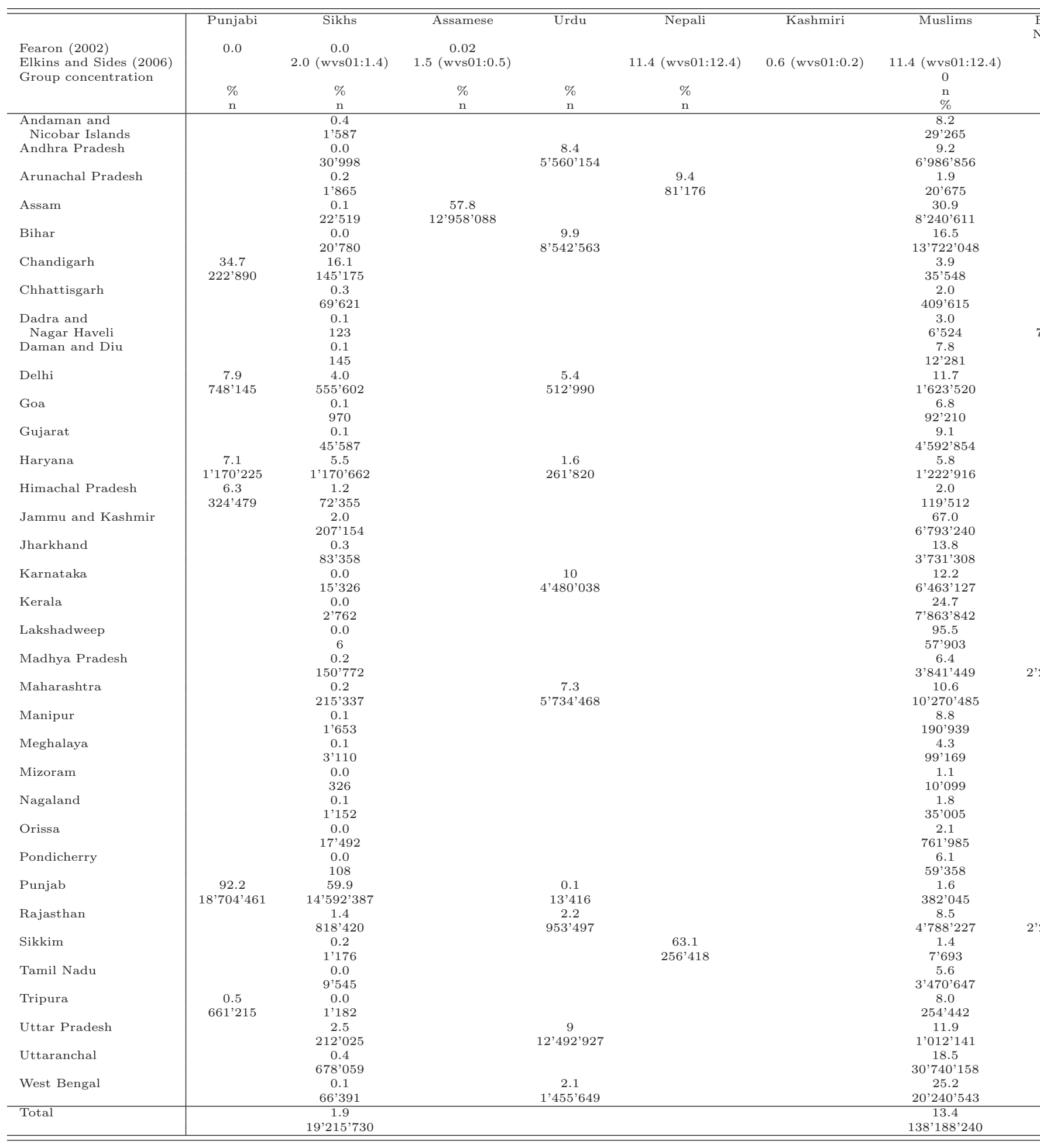


Table 23: India: Multinational Federation (1950 -) Continued

\begin{tabular}{|c|c|c|c|c|c|c|c|c|c|c|}
\hline $\begin{array}{l}\text { Fearon }(2002) \\
\text { Elkins and Sides (2006) } \\
\text { Group concentration }\end{array}$ & $\begin{array}{c}\text { Bodo/ } \\
\text { Boro } \\
0.5 \\
2\end{array}$ & Khasi & Konkani & $\begin{array}{c}\text { Lushai/ } \\
\text { Mizo } \\
0.1 \\
3\end{array}$ & Manipuri & $\begin{array}{l}\text { Nissi/ } \\
\text { Daffla }\end{array}$ & Punjabi & $\begin{array}{c}\text { Tripuri } \\
0.1 \\
3\end{array}$ & Christians & $\overline{\text { Total }}$ \\
\hline & $\%$ & $\%$ & $\%$ & $\%$ & $\%$ & $\%$ & $\%$ & $\%$ & $\mathrm{n}$ & $\%$ \\
\hline & $\mathrm{n}$ & $\mathrm{n}$ & $\mathrm{n}$ & $\mathrm{n}$ & $\mathrm{n}$ & $\mathrm{n}$ & $\mathrm{n}$ & $\mathrm{n}$ & $\%$ & $\mathrm{n}$ \\
\hline $\begin{array}{l}\text { Andaman and } \\
\text { Nicobar Islands }\end{array}$ & & & & & & & & & $\begin{array}{c}21.7 \\
77^{\prime} 178\end{array}$ & $\begin{array}{r}0.0 \\
280^{\prime} 661\end{array}$ \\
\hline \multirow[t]{2}{*}{ Andhra Pradesh } & & & & & & & & & 1.6 & 7.9 \\
\hline & & & & & & 19.9 & & & $\begin{array}{c}1 ' 181 ' 917 \\
18.7\end{array}$ & $\begin{array}{r}66^{\prime} 508^{\prime} 008 \\
0.1\end{array}$ \\
\hline Arunachal Pradesh & & & & & & $172 ' 149$ & & & $205^{\prime} 548$ & $864^{\prime} 558$ \\
\hline \multirow[t]{2}{*}{ Assam } & 5.3 & & & & & & & & 3.7 & 2.6 \\
\hline & 1'184'569 & & & & & & & & $\begin{array}{c}986^{\prime} 589 \\
0.1\end{array}$ & $\begin{array}{r}22^{\prime} 414^{\prime} 322 \\
10.2\end{array}$ \\
\hline Bihar & & & & & & & & & $53^{\prime} 137$ & $86^{\prime} 374^{\prime} 465$ \\
\hline Chandigarh & & & & & & & $\begin{array}{c}34.7 \\
222^{\prime} 890\end{array}$ & & $\begin{array}{c}0.8 \\
7.627\end{array}$ & $\begin{array}{r}0.1 \\
642,015\end{array}$ \\
\hline Chhattisgarh & & & & & & & & & $\begin{array}{c}1.9 \\
401 ’ 035\end{array}$ & \\
\hline Dadra and & & & 12.3 & & & & & & 2.7 & 0.0 \\
\hline Nagar Haveli & & & $17^{\prime} 062$ & & & & & & 6'058 & $138^{\prime} 477$ \\
\hline \multirow[t]{2}{*}{ Daman and Diu } & & & & & & & & & 2.1 & 0.0 \\
\hline & & & & & & & & & 3'362 & $101^{\prime} 586$ \\
\hline Delhi & & & & & & & $\begin{array}{c}7.9 \\
748 ' 145\end{array}$ & & $\begin{array}{c}0.9 \\
130{ }^{\prime} 319\end{array}$ & $\begin{array}{r}1.1 \\
9\end{array}$ \\
\hline \multirow[t]{2}{*}{ Goa } & & & 51.5 & & & & & & 26.7 & $\begin{array}{r}5420044 \\
0.1\end{array}$ \\
\hline & & & $602^{\prime} 626$ & & & & & & $359^{\prime} 568$ & 1'169'793 \\
\hline Gujarat & & & & & & & & & 0.6 & 4.9 \\
\hline Haryana & & & & & & & 7.1 & & $\begin{array}{c}284092 \\
0.1\end{array}$ & $\begin{array}{r}41^{\prime} 309^{\prime} 582 \\
1.9\end{array}$ \\
\hline & & & & & & & 1'170'225 & & $27 ' 185$ & $16^{\prime} 463^{\prime} 648$ \\
\hline Himachal Pradesh & & & & & & & 6.3 & & 0.1 & 0.6 \\
\hline & & & & & & & $324 ' 479$ & & $7^{\prime} 687$ & 5'170' 877 \\
\hline Jammu and Kashmir & & & & & & & & & $\begin{array}{c}0.2 \\
20.299\end{array}$ & 0.9 \\
\hline Jharkhand & & & & & & & & & $\begin{array}{c}20 ' 299 \\
4.1\end{array}$ & $7^{\prime} 718^{\prime} 700$ \\
\hline & & & & & & & & & $1^{\prime} 093^{\prime} 382$ & \\
\hline Karnataka & & & & & & & & & $\begin{array}{c}1.9 \\
1^{\prime} 009^{\prime} 164\end{array}$ & $\begin{array}{r}5.3 \\
44^{\prime} 977^{\prime} 201\end{array}$ \\
\hline Kerala & & & & & & & & & $\begin{array}{l}10.0 \\
19.04\end{array}$ & $\begin{array}{r}44911201 \\
3.4\end{array}$ \\
\hline & & & & & & & & & $6^{\prime} 057^{\prime} 427$ & 29098518 \\
\hline Lakshadweep & & & & & & & & & 0.8 & 0.0 \\
\hline & & & & & & & & & 509 & $51^{\prime} 707$ \\
\hline Madhya Pradesh & & & & & & & & & 0.3 & 7.8 \\
\hline & & & & & & & & & $170^{\prime} 381$ & $66^{\prime} 181^{\prime} 170$ \\
\hline Maharashtra & & & & & & & & & 1.1 & 9.3 \\
\hline & & & & & & & & & 1'058'313 & $78^{\prime} 937^{\prime} 187$ \\
\hline Manipur & & & & & 60.4 & & & & 34.0 & 0.2 \\
\hline & & & & & & & & & $737^{\prime} 578$ & $1^{\prime} 837^{\prime} 149$ \\
\hline Meghalaya & & 49.5 & & & & & & & 70.3 & 0.2 \\
\hline & & $879 ' 192$ & & & & & & & $1^{\prime} 628^{\prime} 986$ & $1^{\prime} 774^{\prime} 778$ \\
\hline Mizoram & & & & 75.1 & & & & & 87.0 & 0.1 \\
\hline & & & & $518^{\prime} 099$ & & & & & $772 ' 809$ & $689^{\prime} 756$ \\
\hline Nagaland & & & & & & & & & 90.0 & 0.1 \\
\hline & & & & & & & & & 1'790'349 & 1'209'546 \\
\hline Orissa & & & & & & & & & 2.4 & 3.7 \\
\hline & & & & & & & & & $897^{\prime} 861$ & $31^{\prime} 659^{\prime} 736$ \\
\hline Pondicherry & & & & & & & & & 6.9 & \\
\hline & & & & & & & & & $67^{\prime} 688$ & $807^{\prime} 785$ \\
\hline Punjab & & & & & & & 92.2 & & 1.2 & \\
\hline & & & & & & & $18^{\prime} 704^{\prime} 461$ & & 292,800 & $20^{\prime} 281^{\prime} 969$ \\
\hline Rajasthan & & & & & & & & & 0.1 & \\
\hline & & & & & & & & & $72^{\prime} 660$ & $44^{\prime} 005^{\prime} 990$ \\
\hline Sikkim & & & & & & & & & 6.7 & \\
\hline & & & & & & & & & $36 \cdot 115$ & $406^{\prime} 457$ \\
\hline Tamil Nadu & & & & & & & & & 6.1 & \\
\hline & & & & & & & & & 3'785'060 & $55^{\prime} 858^{\prime} 946$ \\
\hline Tripura & & & & & & & 0.5 & 23.5 & 3.2 & 0.3 \\
\hline & & & & & & & 661,215 & $647^{\prime} 847$ & $102 ' 489$ & $2^{\prime} 757^{\prime} 205$ \\
\hline Uttar Pradesh & & & & & & & & & 0.3 & 16.4 \\
\hline & & & & & & & & & $27^{\prime} 116$ & $139 ' 112^{\prime} 287$ \\
\hline Uttaranchal & & & & & & & & & 0.1 & \\
\hline & & & & & & & & & $212^{\prime} 578$ & \\
\hline West Bengal & & & & & & & & & 0.6 & 8.0 \\
\hline & & & & & & & & & $515 ' 150$ & $68^{\prime} 077^{\prime} 965$ \\
\hline Total & & & & & & & & & 2.3 & 100 \\
\hline & & & & & & & & & $24^{\prime} 080^{\prime} 016$ & $846^{\prime} 302^{\prime} 688$ \\
\hline
\end{tabular}


Table 24: Malaya: Multinational Federation $\left(1957\right.$ - 1963) ${ }^{a}$

\begin{tabular}{|c|c|c|c|}
\hline Units & $\begin{array}{c}\text { Malay } \\
\% \\
(\mathrm{n})\end{array}$ & $\begin{array}{c}\text { Chinese } \\
\% \\
(\mathrm{n})\end{array}$ & $\begin{array}{c}\text { Indians } \\
\% \\
(\mathrm{n})\end{array}$ \\
\hline \multicolumn{4}{|l|}{ Federated Malay States: } \\
\hline \multicolumn{4}{|l|}{ Perak } \\
\hline \multicolumn{4}{|l|}{ Selangor } \\
\hline \multicolumn{4}{|l|}{ Pahang } \\
\hline \multicolumn{4}{|l|}{ Negeri Sembilan } \\
\hline \multirow{2}{*}{\multicolumn{4}{|c|}{ Unfederated Malay States: }} \\
\hline & \multicolumn{3}{|c|}{ Perlis } \\
\hline \multicolumn{4}{|l|}{ Kedah } \\
\hline \multicolumn{4}{|l|}{ Kelantan } \\
\hline \multicolumn{4}{|l|}{ Terengganu } \\
\hline \multicolumn{4}{|l|}{ Johore } \\
\hline \multicolumn{4}{|l|}{ British Settlements: } \\
\hline \multicolumn{4}{|l|}{ Penang } \\
\hline Malacca & & & \\
\hline
\end{tabular}

${ }^{a}$ In 1963 Singapore, Sabah and Sarawak became member of the new Federation of Malaysia. Singapore is expelled in 1965. 
Table 25: Malaysia: Multinational Federations (1963 -) Census $2000^{a}$

\begin{tabular}{|c|c|c|c|c|c|c|c|c|}
\hline Fearon & $\begin{array}{c}\text { Malays } \\
0.58\end{array}$ & $\begin{array}{l}\text { Chinese } \\
0.25\end{array}$ & $\begin{array}{c}\text { (east) indians } \\
0.07\end{array}$ & Ibans & $\begin{array}{c}\text { Kadazan-Dusun } \\
0.03\end{array}$ & Bajau & Murut & $\begin{array}{c}\text { dayaks } \\
0.03\end{array}$ \\
\hline Fearon (2002) & 0.58 & 0.25 & 0.07 & & 0.03 & & & 0.03 \\
\hline University of Tokyo Institute of Oriental Culture (2003) & 735 & 47 & 12 & & & & & 6 \\
\hline Group concentration & 0 & 0 & 1 & & 3 & & & 3 \\
\hline Units $^{b}$ & $\%$ & $\%$ & $\%$ & $\%$ & $\%$ & $\%$ & $\%$ & $\mathrm{n}$ \\
\hline Johor $^{c}$ & 55 & 36 & 7 & & & & & 2'565'70 \\
\hline $\begin{array}{l}\text { Kedah }^{d} \\
\text { Kelantan }^{e}\end{array}$ & $\begin{array}{l}85 \\
95\end{array}$ & 16 & 8 & & & & & $\begin{array}{l}\text { 1'572'10 } \\
1 ' 289 ' 19\end{array}$ \\
\hline $\begin{array}{l}\text { Kuala Lumpur*f } \\
\text { Labuan*g }\end{array}$ & $>50$ & present & present & & & & & $\begin{array}{r}1^{\prime} 297 ' 52 \\
70 ' 517\end{array}$ \\
\hline Negeri Sembilan ${ }^{i}$ & 46 & 36 & 15 & & & & & $8300^{\prime} 080$ \\
\hline Pahang $j$ & 75 & 19 & 6 & & & & & $1^{\prime} 231 ' 17$ \\
\hline Perak $^{k}$ & 45 & 41 & 14 & & & & & $2^{\prime} 030^{\prime} 38$ \\
\hline Perlis $^{l}$ & 78 & 17 & 2 & & & & & $198^{\prime} 335$ \\
\hline Pulau Pinang ${ }^{m}$ & 41 & 43 & 10 & & & & & $1,225{ }^{\prime} 50$ \\
\hline \multicolumn{9}{|l|}{ Putrajaya*n } \\
\hline $\mathrm{Sabah}^{\circ}$ & 15 & 20 & & & 25 & 17 & 3 & 2'449'38 \\
\hline Sarawak $^{p}$ & 23 & 27 & & 30 & & & & 2'012'61 \\
\hline Selangor $^{q}$ & 44 & 35 & 18 & & & & & $3^{\prime} 947^{\prime} 52$ \\
\hline Terrengganu ${ }^{s}$ & $\begin{array}{l}44 \\
94\end{array}$ & $\begin{array}{c}30 \\
5\end{array}$ & 1 & & & & & 879,691 \\
\hline
\end{tabular}

${ }^{a}$ http://www.statistics.gov.my/english/frameset_census.php?file=pressdemo and Wikipedia

${ }^{b}$ The information for the federal units as well as the population sizes (2000) comes from http://www.statoids.com/umy.html.

${ }^{c}$ http://en.wikipedia.org/wiki/Johore

${ }^{d}$ http://en.wikipedia.org/wiki/Kedah

${ }^{e}$ http://en.wikipedia.org/wiki/Kelantan

${ }^{f}$ In 1 February 1972 Kuala Lumpur seceded from Selangor and the city became a Federal Territory (Wilayah Persekutuan).

${ }^{g}$ in 1984, Labuan was transferred from Sabah to the central government and made a Federal Territory. In 1990, it was declared an International Offshore Financial Centre and Free Trade Zone.

${ }^{h}$ http://en.wikipedia.org/wiki/Melaka

${ }^{i}$ http://en.wikipedia.org/wiki/Negeri_Sembilan

${ }^{j}$ http://en.wikipedia.org/wiki/Pahang

${ }^{k}$ http://en.wikipedia.org/wiki/Perak

${ }^{l}$ http://en.wikipedia.org/wiki/Perlis

${ }^{m}$ http://en.wikipedia.org/wiki/Penang

${ }^{n}$ Putrajaya was founded on October 19, 1995. It is the new administrative centre of Malaysia

${ }^{o}$ http://en.wikipedia.org/wiki/Sabah

${ }^{p}$ http://en.wikipedia.org/wiki/Sarawak

${ }^{q}$ http://en.wikipedia.org/wiki/Selangor

$r_{\mathrm{n}}$ include Putrajaya

${ }^{s}$ http://en.wikipedia.org/wiki/Terengganu

${ }^{t}$ Singapore was member of the Federation of Malaysia only 2 years (1963 - 1965)

${ }^{u}$ Without Singapore. http://www.statistics.gov.my/english/frameset_census.php?file=pressdemo 
Table 26: Mali: Multinational Federation (1960 - 1960) DHS Survey 1999

\begin{tabular}{|c|c|c|c|c|c|c|c|}
\hline \multirow{3}{*}{$\begin{array}{l}\text { Fearon }(2002) \\
\text { Group concentration } \\
\text { DHS Groups } \\
\text { Units }^{a}\end{array}$} & \multicolumn{2}{|c|}{$\begin{array}{c}\text { Mande } \\
0.43\end{array}$} & $\begin{array}{c}\text { Peul Fulani } \\
0.15\end{array}$ & $\begin{array}{c}\text { Senufo } \\
0.15\end{array}$ & $\begin{array}{c}\text { Sarakole-Soninke } \\
0.08\end{array}$ & $\begin{array}{l}\text { Songhai } \\
0.06\end{array}$ & $\begin{array}{c}\text { Tuareg } \\
0.06 \\
3\end{array}$ \\
\hline & $\underset{\%}{\text { Bambara }}$ & $\underset{\%}{\operatorname{Malinke}}$ & $\begin{array}{l}\text { Peulh } \\
\%\end{array}$ & $\underset{\%}{\text { Senoufo / }}$ & Sarakole / Soninke / & $\underset{\%}{\text { Sonrai }}$ & $\underset{\%}{\text { Tamacheck }}$ \\
\hline & $\mathrm{n}$ & $\mathrm{n}$ & $\mathrm{n}$ & $\mathrm{n}$ & $\mathrm{n}$ & $\mathrm{n}$ & $\mathrm{n}$ \\
\hline \multirow[t]{2}{*}{ Bamako } & 33.7 & 13.2 & 15.8 & 7 & 13 & 5.3 & 1.3 \\
\hline & 685 & 268 & 322 & 142 & 265 & 107 & 26 \\
\hline \multirow[t]{2}{*}{ Gao } & 1.3 & 0 & 3.5 & 0 & 0.9 & 84.7 & 6.1 \\
\hline & 3 & 0 & 8 & 0 & 2 & 194 & 14 \\
\hline \multirow[t]{2}{*}{ Kayes } & 11.2 & 29 & 20.4 & 0.3 & 35.7 & 0.2 & 2.4 \\
\hline & 190 & 492 & 347 & 5 & 606 & 3 & 40 \\
\hline \multirow[t]{2}{*}{ Kidal } & 5 & 0 & 5 & 0 & 0 & 10 & 80 \\
\hline & 1 & 0 & 1 & 0 & 0 & 2 & 16 \\
\hline \multirow[t]{2}{*}{ Koulikoro } & 59.4 & 12.2 & 7.4 & 1 & 13.5 & 1.1 & 2.8 \\
\hline & 1213 & 249 & 152 & 21 & 276 & 22 & 57 \\
\hline \multirow[t]{2}{*}{ Mopti } & 8.9 & 2.7 & 24.6 & 0.3 & 7.2 & 6.6 & 1.2 \\
\hline & 157 & 48 & 432 & 5 & 126 & 116 & 21 \\
\hline \multirow[t]{2}{*}{ Segou } & 47.2 & 2.3 & 9.8 & 11.3 & 10.8 & 2.3 & 1.6 \\
\hline & 968 & 47 & 201 & 232 & 221 & 48 & 33 \\
\hline \multirow[t]{2}{*}{ Sikasso } & 40.7 & 2.9 & 11.7 & 27.6 & 3.5 & 1.1 & 0.3 \\
\hline & 969 & 68 & 279 & 657 & 83 & 27 & 6 \\
\hline \multirow{2}{*}{ Tombouctou } & 13.9 & 0.7 & 12.9 & 0.2 & 1 & 58.5 & 10.3 \\
\hline & 58 & 3 & 54 & 1 & 4 & 244 & 43 \\
\hline \multirow[t]{2}{*}{ Total } & 33.6 & 9.3 & 14.2 & 8.4 & 12.5 & 6 & 2 \\
\hline & $4^{\prime} 244$ & $1^{\prime} 175$ & $1^{\prime} 796$ & 1'063 & $1^{\prime} 583$ & 763 & 256 \\
\hline
\end{tabular}

${ }^{a}$ Information on units and population sizes come from http://www.statoids.com/uml.html

Table 27: Mali: Multinational Federation (1960 - 1960) Continued

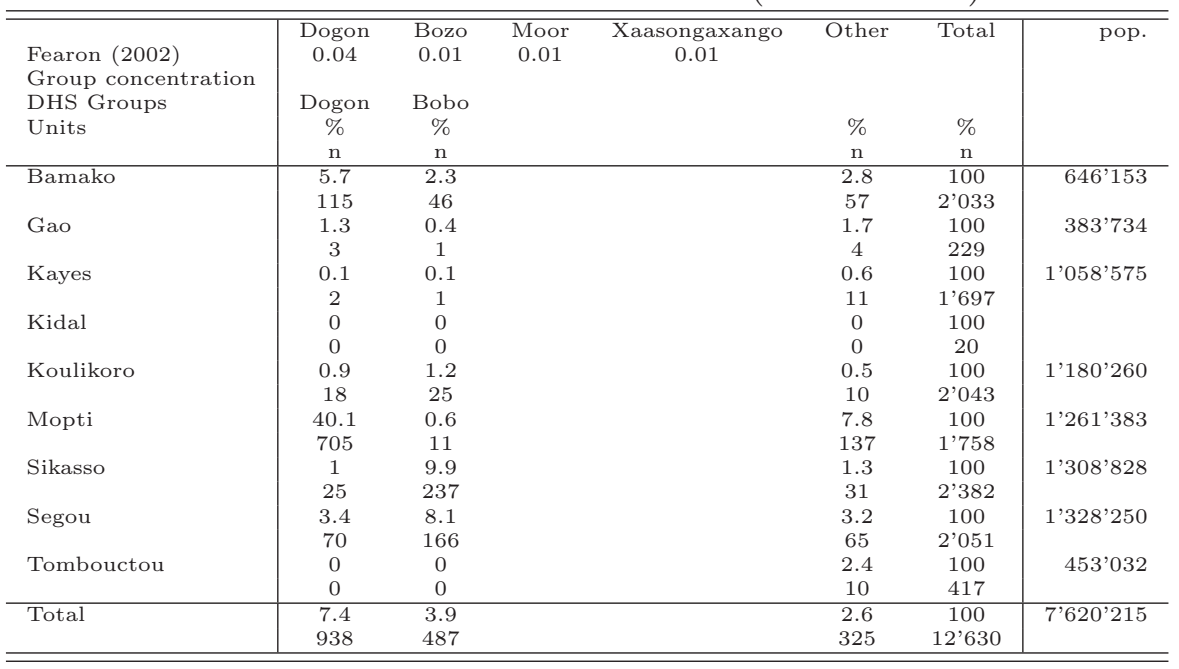


Table 28: Mexico: National federation ( 1917 - ) Census 2000

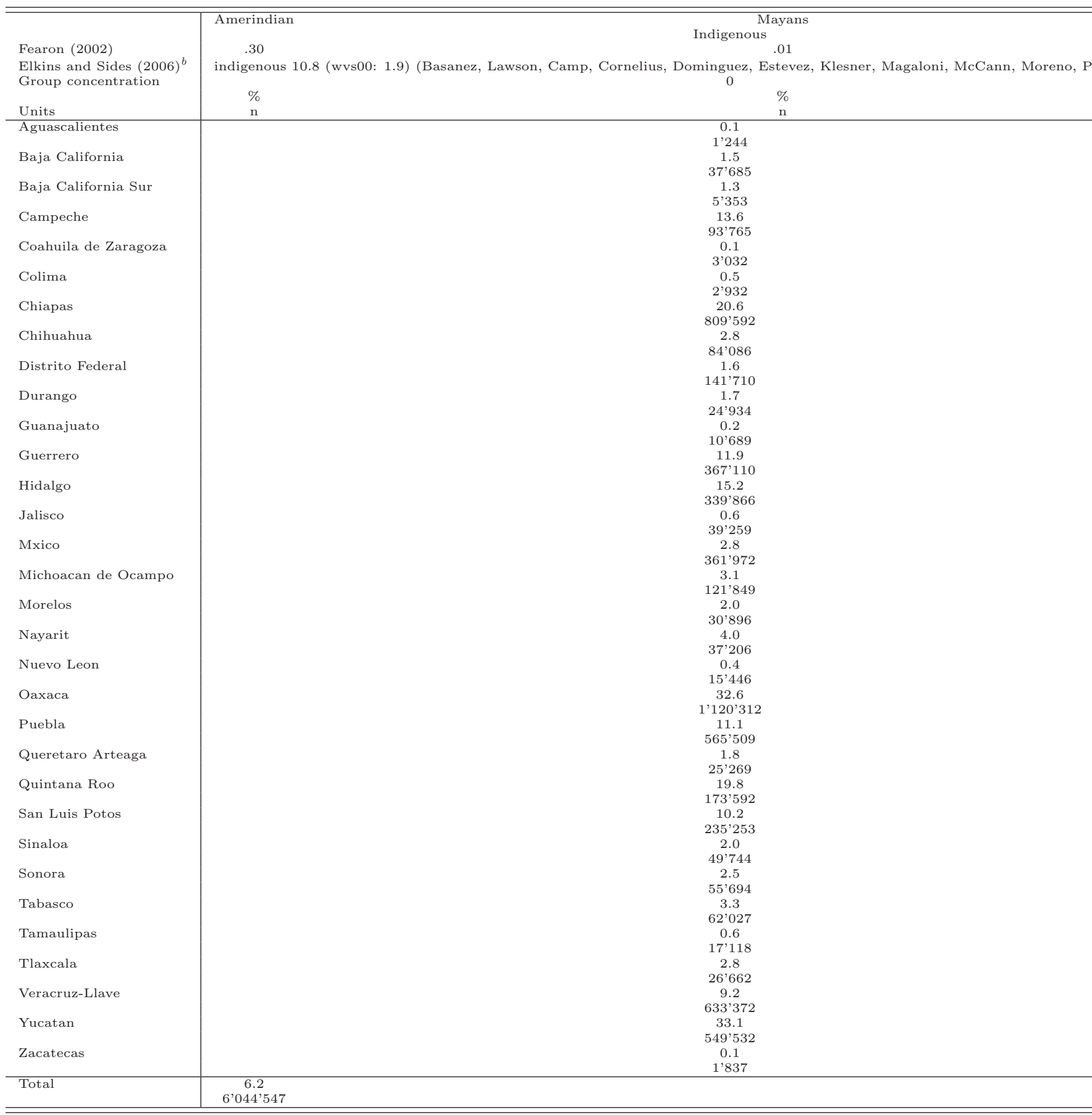

${ }^{a}$ Instituto Nacional de Estadistica Geografia e informatica. Percentage of the population speaking an indigenous language; http://www.inegi.gob.mx/est/contenidos/espanol/rutinas/ept.asp?t $=$ mlen02\&c $=3327$

${ }^{b}$ While there are three WVS carried out in Mexico (1990, 1996, and 2000), the information on residency only covered 4 regions, which fail to correspond to any of the $31+1$ federal units.

${ }^{c}$ This survey has blanco (16.3) moreno claro (45.5) moreno oscuro (38.3). (variable d3, x3 is estados). 
Table 29: Nigeria: Multinational Federation (1960 -) DHS Survey 1999

\begin{tabular}{|c|c|c|c|c|c|c|}
\hline \multirow{2}{*}{$\begin{array}{l}\text { Fearon }(2002) \\
\text { Elkins and Sides }(2006)^{a} \\
\text { Group concentration }\end{array}$} & $\begin{array}{c}\text { Hausa-Fulani } \\
0.29 \\
29.0\end{array}$ & $\begin{array}{c}\text { Yoruba } \\
0.2 \\
20.0(\text { wvs00:25.5) }\end{array}$ & $\begin{array}{c}\text { Ibo } \\
0.17 \\
17.0 \text { (wvs00:21.0) }\end{array}$ & \multicolumn{2}{|c|}{$\begin{array}{c}\text { Ibibio - Efik - Ijaw } \\
0.08 \\
3.6\end{array}$} & $\begin{array}{c}\text { Kanuri } \\
0.05\end{array}$ \\
\hline & \multirow[b]{2}{*}{$\begin{array}{c}\text { Hausa and Fulani } \\
\%\end{array}$} & 3 & 2 & \multicolumn{2}{|c|}{3} & \\
\hline & & $\begin{array}{c}\text { Yoruba } \\
\%\end{array}$ & $\begin{array}{l}\text { Igbo } \\
\%\end{array}$ & $\begin{array}{c}\text { Ibibio } \\
\%\end{array}$ & $\begin{array}{l}\text { Ijaw } \\
\%\end{array}$ & $\begin{array}{c}\text { Kanuri } \\
\%\end{array}$ \\
\hline Units & $\mathrm{n}$ & $\mathrm{n}$ & $\mathrm{n}$ & $\mathrm{n}$ & $\mathrm{n}$ & $\mathrm{n}$ \\
\hline \multirow{2}{*}{ Akwa Ibom } & 0.0 & 0.1 & 1.8 & 61.2 & 0.0 & 0.0 \\
\hline & 0 & 1 & 13 & 438 & 0 & 0 \\
\hline \multirow{2}{*}{ Anambra } & 1.0 & 0.0 & 98.7 & 0.3 & 0.0 & 0.0 \\
\hline & $\begin{array}{c}3 \\
46.9\end{array}$ & 0 & $\begin{array}{l}309 \\
18\end{array}$ & 1 & 0 & 0 \\
\hline D. & & $\begin{array}{c}1.1 \\
3\end{array}$ & $\begin{array}{c}1.8 \\
5\end{array}$ & $\begin{array}{c}0.0 \\
0\end{array}$ & $\begin{array}{c}0.0 \\
0\end{array}$ & $\begin{array}{c}0.0 \\
0\end{array}$ \\
\hline Edo & 0.0 & 2.1 & 3.1 & 0.0 & 1.5 & 0.0 \\
\hline Benue & 0.5 & 0.5 & $\begin{array}{l}10 \\
9.3\end{array}$ & 0.0 & $\begin{array}{c}5 \\
0.0\end{array}$ & $\begin{array}{c}0 \\
0.0\end{array}$ \\
\hline & 2 & 2 & 34 & 0 & 0 & 0 \\
\hline Borno & 11.8 & 0.0 & 0.6 & 0.0 & 0.0 & 15.7 \\
\hline & 21 & & 1 & 0 & 0 & 28 \\
\hline Cross River & 0.0 & 0.0 & 2.4 & 8.7 & 0.0 & 0.0 \\
\hline & 0 & 0 & 3 & 11 & 0 & 0 \\
\hline Adamawa & 17.9 & 0.0 & 0.0 & 0.0 & 0.0 & 0.0 \\
\hline & 36 & 0 & 0 & 0 & 0 & 0 \\
\hline Imo & 0.0 & 0.5 & 99.1 & 0.5 & 0.0 & 0.0 \\
\hline & 0 & 1 & 216 & 1 & 0 & 0 \\
\hline Kaduna & 50.9 & 2.5 & 4.2 & 0.7 & 0.0 & 1.1 \\
\hline & 144 & 7 & 12 & 2 & 0 & 3 \\
\hline Kano & 92.2 & 1.3 & 0.5 & 0.0 & 0.0 & 0.4 \\
\hline & 506 & 7 & 3 & 0 & 0 & 2 \\
\hline Katsina & 97.3 & 0.8 & 0.5 & 0.0 & 0.0 & 0.3 \\
\hline & 354 & 3 & 2 & 0 & 0 & 1 \\
\hline Kwara & 0.0 & 86.0 & 0.4 & 0.4 & 0.0 & 0.0 \\
\hline & 0 & 208 & 1 & 1 & 0 & 0 \\
\hline Lagos & 2.0 & 66.4 & 19.0 & 0.4 & 0.0 & 0.0 \\
\hline & 10 & 336 & 96 & 2 & 0 & 0 \\
\hline Niger & 9.6 & 7.8 & 7.8 & 0.0 & 0.0 & 0.0 \\
\hline & 28 & 23 & 23 & 0 & 0 & 0 \\
\hline Ogun & 0.3 & 79.3 & 3.8 & 0.0 & 0.0 & 0.0 \\
\hline & 1 & 249 & 12 & 0 & 0 & 0 \\
\hline Ondo & 0.0 & 89.6 & 4.9 & 0.0 & 0.0 & 0.0 \\
\hline & 0 & 163 & 9 & 0 & 0 & 0 \\
\hline Oyo & 0.7 & 94.7 & 0.7 & 0.5 & 0.0 & 0.0 \\
\hline & 3 & 410 & 3 & 2 & 0 & 0 \\
\hline Plateau & 13.4 & 2.1 & 2.9 & 0.0 & 0.0 & 0.0 \\
\hline & 32 & 5 & 7 & 0 & 0 & 0 \\
\hline Rivers & 0.0 & 0.9 & 34.0 & 2.4 & 15.6 & 0.0 \\
\hline & 0 & 2 & 72 & 5 & 33 & 0 \\
\hline Sokoto & 100.0 & 0.0 & 0.0 & 0.0 & 0.0 & 0.0 \\
\hline & 175 & 0 & 0 & 0 & 0 & 0 \\
\hline Abia & 0.0 & 0.0 & 99.2 & 0.0 & 0.4 & 0.0 \\
\hline & 0 & 0 & 237 & 0 & 1 & 0 \\
\hline Delta & 0.0 & 2.0 & 36.9 & 1.6 & 15.4 & 0.0 \\
\hline & 0 & 6 & 113 & 5 & 47 & 0 \\
\hline Enugu & 0.0 & 0.0 & 99.4 & 0.0 & 0.0 & 0.0 \\
\hline & 0 & 0 & 164 & 0 & 0 & 0 \\
\hline Jigawa & 88.7 & 0.0 & 0.0 & 0.0 & 0.0 & 4.4 \\
\hline & 180 & ${ }_{0}^{0}$ & 0 & 0 & 0 & 9 \\
\hline Kebbi & 77.7 & 1.5 & 0.0 & 0.0 & 0.0 & 0.0 \\
\hline & 157 & 3 & 0 & 0 & 0 & 0 \\
\hline Kogi & 0.2 & 32.9 & 2.1 & 0.0 & 0.0 & 0.0 \\
\hline & 1 & 156 & 10 & 0 & 0 & 0 \\
\hline Osun & 0.4 & 97.3 & 0.0 & 0.0 & 0.0 & 0.0 \\
\hline & 1 & 249 & 0 & 0 & 0 & 0 \\
\hline Taraba & 12.4 & 1.5 & 9.3 & 0.0 & 0.0 & 3.6 \\
\hline & 24 & 3 & 18 & 0 & 0 & 7 \\
\hline Yobe & 29.8 & 0.4 & $\begin{array}{l}1.2 \\
\text { L }\end{array}$ & 0.0 & 0.0 & 5.2 \\
\hline & 75 & 1 & 3 & 0 & 0 & 13 \\
\hline Bayelsa & 0.0 & 0.0 & 4.8 & 0.0 & 88.7 & 0.0 \\
\hline & 0 & 0 & & 0 & 55 & 0 \\
\hline Ebonyi & 0.0 & 0.0 & 100.0 & 0.0 & 0.0 & 0.0 \\
\hline & 0 & 0 & 171 & 0 & 0 & 0 \\
\hline Ekiti & 0.0 & 79.1 & 0.0 & 0.0 & 0.0 & 0.0 \\
\hline & 0 & 87 & 0 & 0 & 0 & 0 \\
\hline Gombe & 43.4 & 0.0 & 2.7 & 0.0 & 0.0 & 0.0 \\
\hline & 49 & 0 & 3 & 0 & 0 & 0 \\
\hline Nassarawa & 29.1 & 0.0 & 3.9 & 0.0 & 0.0 & 2.9 \\
\hline & 30 & 0 & 4 & 0 & 0 & 3 \\
\hline Zamfara & 100.0 & 0.0 & 0.0 & 0.0 & 0.0 & 0.0 \\
\hline & 240 & 0 & 0 & 0 & 0 & 0 \\
\hline F.C.T. (Abuja) & 29.2 & 6.2 & 6.2 & 0.0 & 0.0 & 0.0 \\
\hline & 19 & 4 & 4 & 0 & 0 & 0 \\
\hline Total & 23.0 & 20.0 & 16.2 & 4.8 & 1.5 & 0.7 \\
\hline & $2^{\prime} 219$ & 1'936 & $1 ' 561$ & 468 & 141 & 66 \\
\hline
\end{tabular}

${ }^{a}$ While there are three WVS (1990, 1995, and 2000) none contains simultaneously information on language and regions. 
Table 30: Nigeria: Multinational Federation (1960 -) Continued

\begin{tabular}{|c|c|c|c|c|c|c|}
\hline \multirow{5}{*}{$\begin{array}{l}\text { Fearon }(2002) \\
\text { Elkins and Sides (2006) } \\
\text { Group concentration }\end{array}$} & \multicolumn{6}{|c|}{ Ogoni } \\
\hline & \multirow{2}{*}{\multicolumn{6}{|c|}{0.03}} \\
\hline & & & & & & \\
\hline & \multirow[b]{2}{*}{$\begin{array}{c}\text { Edo } \\
\%\end{array}$} & 3 & & & & \\
\hline & & $\underset{\%}{\text { Ogoni }}$ & $\begin{array}{c}\text { Igbala } \\
\%\end{array}$ & $\begin{array}{c}\text { Ibira } \\
\%\end{array}$ & $\begin{array}{c}\text { Idoma } \\
\%\end{array}$ & $\underset{\%}{\text { Annang }}$ \\
\hline Units & $\mathrm{n}$ & $\mathrm{n}$ & $\mathrm{n}$ & $\mathrm{n}$ & $\mathrm{n}$ & $\mathrm{n}$ \\
\hline \multirow{2}{*}{ Akwa Ibom } & 0.0 & 0.0 & 0.0 & 0.0 & 0.0 & 17.5 \\
\hline & 0 & 0 & 0 & 0 & 0 & 125 \\
\hline Anambra & 0.0 & 0.0 & 0.0 & 0.0 & 0.0 & 0.0 \\
\hline & 0 & 0 & 0 & 0 & 0 & 0 \\
\hline Bauchi & 0.0 & 0.0 & 0.7 & 0.0 & 0.0 & 0.0 \\
\hline & 0 & 0 & 2 & 0 & 0 & 0 \\
\hline Edo & 60.1 & 0.0 & 9.8 & 18.7 & 0.0 & 0.0 \\
\hline & 196 & 0 & 32 & 61 & 0 & 0 \\
\hline Benue & 0.0 & 0.0 & 4.6 & 0.0 & 40.7 & 0.0 \\
\hline & 0 & 0 & 17 & 0 & 149 & 0 \\
\hline Borno & 0.0 & 0.0 & 0.0 & 1.7 & 2.2 & 0.0 \\
\hline & 0 & 0 & 0 & 3 & 4 & 0 \\
\hline Cross River & 0.0 & 0.0 & 0.0 & 0.0 & 0.0 & 5.6 \\
\hline & 0 & 0 & 0 & 0 & 0 & 7 \\
\hline Adamawa & 0.0 & 0.0 & 0.0 & 0.0 & 0.0 & 0.0 \\
\hline & 0 & 0 & 0 & 0 & 0 & 0 \\
\hline Imo & 0.0 & 0.0 & 0.0 & 0.0 & 0.0 & 0.0 \\
\hline & 0 & 0 & 0 & 0 & 0 & 0 \\
\hline Kaduna & 0.4 & 0.0 & 0.0 & 0.0 & 0.7 & 0.0 \\
\hline & 1 & 0 & 0 & 0 & 2 & 0 \\
\hline Kano & 0.2 & 0.0 & 0.9 & 0.0 & 0.9 & 0.0 \\
\hline & 1 & 0 & 5 & 0 & 5 & 0 \\
\hline Katsina & 0.0 & 0.0 & 0.0 & 0.0 & 0.0 & 0.0 \\
\hline & 0 & 0 & 0 & 0 & 0 & 0 \\
\hline Kwara & 0.0 & 0.0 & 0.0 & 0.8 & 0.0 & 0.0 \\
\hline & 0 & 0 & 0 & 2 & 0 & 0 \\
\hline Lagos & 1.2 & 0.0 & 0.8 & 1.2 & 0.2 & 0.0 \\
\hline & 6 & 0 & 4 & 6 & 1 & 0 \\
\hline Niger & 0.3 & 0.0 & 0.3 & 0.7 & 0.7 & 0.0 \\
\hline & 1 & 0 & 1 & 2 & 2 & 0 \\
\hline Ogun & 3.2 & 0.0 & 0.0 & 0.3 & 0.6 & 0.0 \\
\hline & 10 & 0 & 0 & 1 & 2 & 0 \\
\hline Ondo & 0.0 & 0.0 & 1.6 & 0.0 & 2.2 & 0.0 \\
\hline & 0 & 0 & 3 & 0 & 4 & 0 \\
\hline Оуо & 0.0 & 0.0 & 0.0 & 0.2 & 0.0 & 0.0 \\
\hline & 0 & 0 & 0 & 1 & 0 & 0 \\
\hline Plateau & 0.4 & 0.0 & 0.0 & 0.0 & 0.0 & 0.0 \\
\hline & 1 & 0 & 0 & 0 & 0 & 0 \\
\hline Rivers & 0.5 & 17.9 & 0.0 & 0.0 & 0.5 & 0.0 \\
\hline & 1 & 38 & 0 & 0 & 1 & 0 \\
\hline Sokoto & 0.0 & 0.0 & 0.0 & 0.0 & 0.0 & 0.0 \\
\hline & 0 & 0 & 0 & 0 & 0 & 0 \\
\hline Abia & 0.0 & 0.0 & 0.0 & 0.0 & 0.0 & 0.0 \\
\hline & 0 & 0 & 0 & 0 & 0 & 0 \\
\hline Delta & 7.2 & 0.7 & 1.0 & 0.3 & 0.0 & 0.0 \\
\hline & 22 & 2 & 3 & 1 & 0 & 0 \\
\hline Enugu & 0.0 & 0.0 & 0.0 & 0.0 & 0.0 & 0.0 \\
\hline & 0 & 0 & 0 & 0 & 0 & 0 \\
\hline Jigawa & 0.0 & 0.0 & 0.0 & 0.0 & 0.0 & 0.0 \\
\hline & 0 & 0 & 0 & 0 & 0 & 0 \\
\hline Kebbi & 0.0 & 0.0 & 0.0 & 0.0 & 0.0 & 0.0 \\
\hline & 0 & 0 & 0 & 0 & 0 & 0 \\
\hline Kogi & 0.0 & 12.9 & 31.6 & 19.6 & 0.2 & 0.0 \\
\hline & 0 & 61 & 150 & 93 & 1 & 0 \\
\hline Osun & 0.0 & 0.0 & 0.0 & 0.0 & 0.4 & 0.0 \\
\hline & 0 & 0 & 0 & 0 & 1 & 0 \\
\hline Taraba & 0.0 & 0.0 & 0.5 & 0.0 & 1.0 & 0.0 \\
\hline & 0 & 0 & 1 & 0 & 2 & 0 \\
\hline Yobe & 0.0 & 0.0 & 0.0 & 0.0 & 0.0 & 0.0 \\
\hline & 0 & 0 & 0 & 0 & 0 & 0 \\
\hline Bayelsa & 0.0 & 0.0 & 0.0 & 0.0 & 0.0 & 0.0 \\
\hline & 0 & 0 & 0 & 0 & 0 & 0 \\
\hline Ebonyi & 0.0 & 0.0 & 0.0 & 0.0 & 0.0 & 0.0 \\
\hline & 0 & 0 & 0 & 0 & 0 & 0 \\
\hline Ekiti & 0.0 & 0.0 & 0.9 & 16.4 & 0.0 & 0.0 \\
\hline & 0 & 0 & 1 & 18 & 0 & 0 \\
\hline Gombe & 0.0 & 0.0 & 0.0 & 0.0 & 0.0 & 0.0 \\
\hline & 0 & 0 & 0 & 0 & 0 & 0 \\
\hline Nassarawa & 0.0 & 0.0 & 1.0 & 0.0 & 0.0 & 0.0 \\
\hline & 0 & 0 & 1 & 0 & 0 & 0 \\
\hline Zamfara & 0.0 & 0.0 & 0.0 & 0.0 & 0.0 & 0.0 \\
\hline & 0 & 0 & 0 & 0 & 0 & 0 \\
\hline F.C.T. (Abuja) & 0.0 & 0.0 & 13.8 & 3.1 & 1.5 & 0.0 \\
\hline & 0 & 0 & 9 & 2 & 1 & 0 \\
\hline Total & 2.5 & 1.0 & 2.4 & 2.0 & 1.8 & 1.4 \\
\hline & 239 & 101 & 229 & 190 & 175 & 132 \\
\hline
\end{tabular}


Table 31: Nigeria: Multinational Federation (1960 -) Continued

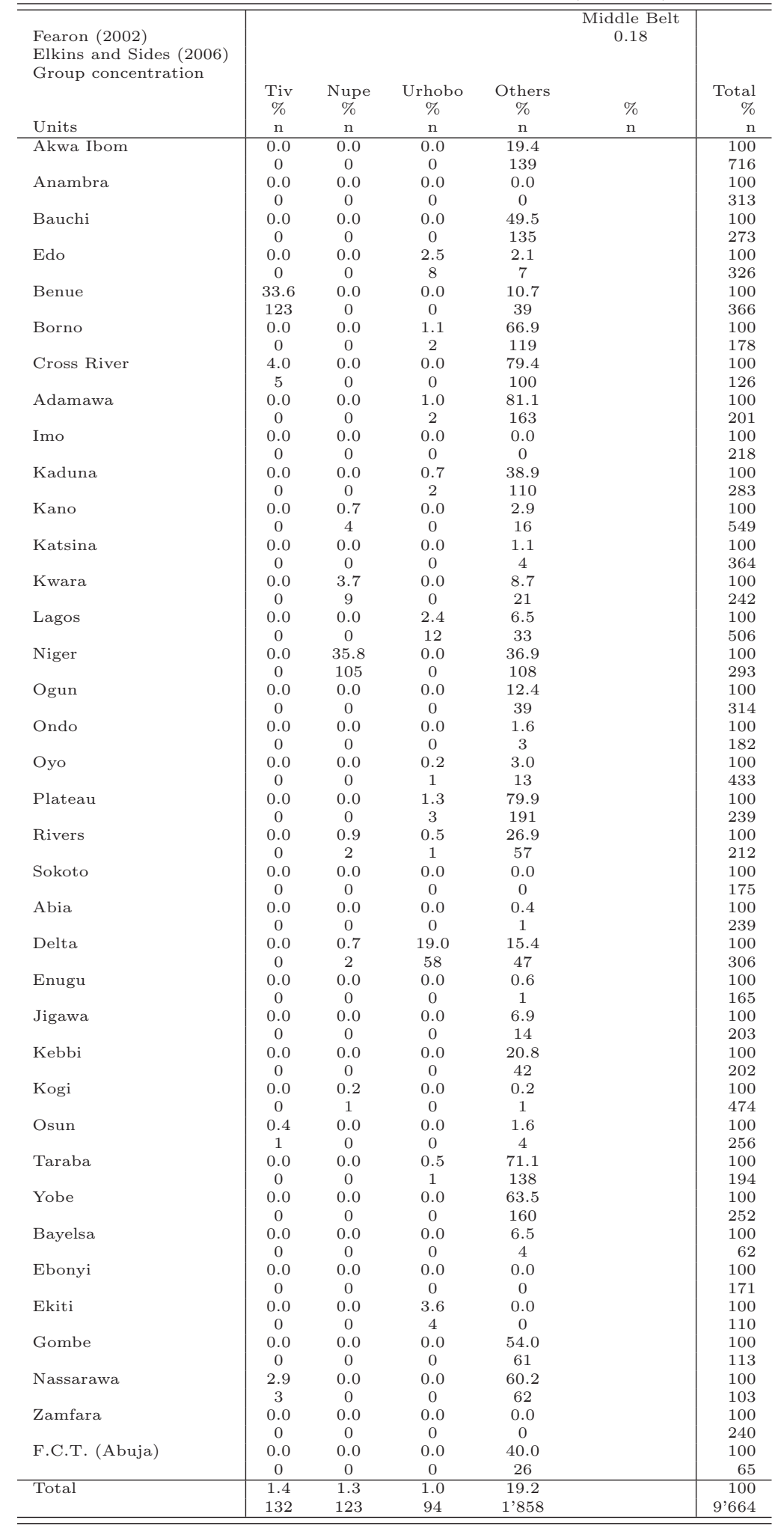


Table 32: Pakistan: Multinational Federation (1947 - 1971)

\begin{tabular}{|c|c|c|c|c|c|c|c|c|c|c|c|c|c|}
\hline \multirow{5}{*}{$\begin{array}{l}\text { Fearon }(2002) \\
\text { Group concentration } \\
\text { Fearon }(2002) \\
\text { Units }^{b}\end{array}$} & \multirow{2}{*}{\multicolumn{2}{|c|}{$\begin{array}{l}\text { Punjabi } \\
0.66\end{array}$}} & \multicolumn{2}{|c|}{ Sindhi } & \multicolumn{2}{|c|}{ Pashtuns (Pushtuns) } & \multicolumn{2}{|c|}{ Mohajirs } & \multicolumn{2}{|c|}{ Baluchis } & \multicolumn{2}{|c|}{ Urdu } & \multirow[t]{4}{*}{$\overline{\text { pop }}$} \\
\hline & & & 0.13 & & 0.09 & & 0.08 & & 0.03 & & & & \\
\hline & & & & & & 3 & & & & & & & \\
\hline & 0.7 & & 0 & & 0.1 & & 0.08 & & 0.03 & & & & \\
\hline & $\%$ & (n) & $\%$ & $(\mathrm{n})$ & $\%$ & (n) & $\%$ & (n) & $\%$ & $(\mathrm{n})$ & $\%$ & $(\mathrm{n})$ & (n) \\
\hline Azad Kashmir & & & & & & & & & & & & & $2,800,000$ \\
\hline Balochistan & 7.9 & 8 & 4.0 & 4 & 51.5 & 0 & & & 36.6 & 37 & & & $6,565,885$ \\
\hline Federally Administered Tribal Areas & & & & & & 0 & & & & & & & $3,176,331$ \\
\hline Islamabad & 0.0 & 0 & 0.0 & 0 & 90.0 & 0 & 0.0 & 0 & 0.0 & 0 & 0.0 & 0 & 805,235 \\
\hline Northern Areas & & & & & & 0 & & & & & & & 910,000 \\
\hline North-West Frontier & 9.7 & 27 & 0.0 & 0 & 87.8 & 0 & 0.0 & 0 & 0.0 & 0 & 2.5 & 7 & $17,743,645$ \\
\hline Punjab & 95.3 & 1105 & 0.3 & 4 & 3.7 & 0 & 0.0 & 0 & 0.6 & 8 & 0.0 & 0 & $73,621,290$ \\
\hline Sindh & 36.0 & 162 & 40.2 & 181 & 3.6 & 0 & 0.0 & 0.0 & 1.1 & 5 & 19.1 & 86 & $30,439,893$ \\
\hline Total & 65.6 & 1311 & 9.5 & 189 & 17.9 & 357 & 0.0 & 0.0 & 2.5 & 50 & 4.7 & 93 & $30,439,893$ \\
\hline
\end{tabular}

${ }^{a}$ MAR cites in addition Ahmadis (0), Hindus (3)

${ }^{b}$ Federal units and population size (1998 census) from www.statoids.com.

Table 33: Pakistan: Multinational Federations (1947 - 1971) WVS 1999

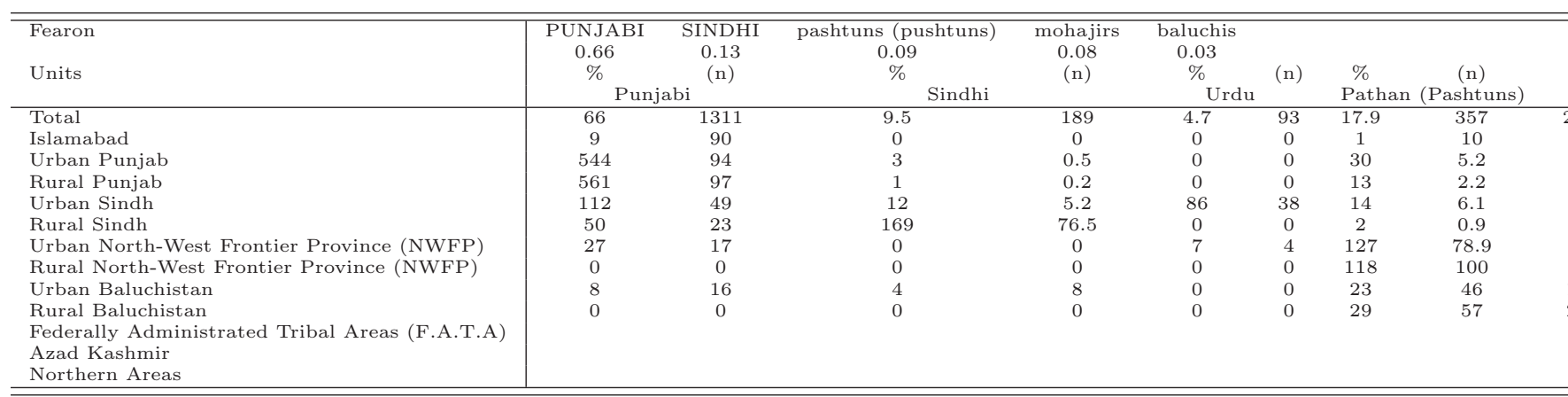

Table 34: Pakistan: Multinational Federations (1947 - 1971) DHS Survey $1990 / 1991$

\begin{tabular}{|c|c|c|c|c|c|c|c|c|c|c|}
\hline Fearon & $\begin{array}{l}\text { PUNJABI } \\
0.66\end{array}$ & $\begin{array}{l}\text { SINDHI } \\
0.13\end{array}$ & $\begin{array}{c}\text { pashtuns (pushtuns) } \\
0.09\end{array}$ & $\begin{array}{c}\text { mohajirs } \\
0.08\end{array}$ & $\begin{array}{c}\text { baluchis } \\
0.03\end{array}$ & & & & & \\
\hline Units & $\begin{array}{c}\text { Punjabi } \\
\text { n } \\
\%\end{array}$ & $\begin{array}{c}\text { Sindhi } \\
\mathrm{n} \\
\%\end{array}$ & $\begin{array}{c}\text { Pushto } \\
\mathrm{n} \\
\%\end{array}$ & $\begin{array}{c}\text { Urdu } \\
\mathrm{n} \\
\%\end{array}$ & $\begin{array}{c}\text { Siraiki } \\
\mathrm{n} \\
\%\end{array}$ & $\begin{array}{c}\text { Hindko } \\
\text { n } \\
\%\end{array}$ & $\begin{array}{c}\text { Brohi } \\
\text { n } \\
\%\end{array}$ & $\begin{array}{c}\text { Baluchi } \\
\mathrm{n} \\
\%\end{array}$ & $\begin{array}{c}\text { Other } \\
\text { n } \\
\%\end{array}$ & $\begin{array}{c}\text { Total } \\
\mathrm{n} \\
\%\end{array}$ \\
\hline \multirow[t]{2}{*}{ Punjab } & 2848 & 32 & 86 & 300 & 616 & 2 & 19 & 2 & 44 & 3949 \\
\hline & 72.1 & 0.8 & 2.2 & 7.6 & 15.6 & 0.1 & 0.5 & 0.1 & 1.1 & 100 \\
\hline \multirow[t]{2}{*}{ Sindh } & 51 & 915 & 22 & 454 & 10 & 5 & 3 & 17 & 51 & 1528 \\
\hline & 3.3 & 59.9 & 1.4 & 29.7 & 0.7 & 0.3 & 0.2 & 1.1 & 3.3 & 100 \\
\hline \multirow[t]{2}{*}{ NW Frontier } & 6 & 0 & 652 & 20 & 58 & 143 & 0 & 0 & 0 & 879 \\
\hline & 0.7 & 0.0 & 74.2 & 2.3 & 6.6 & 16.3 & 0.0 & 0.0 & 0.0 & 100 \\
\hline \multirow[t]{2}{*}{ Balochistan } & 2 & 30 & 58 & 13 & 3 & 0 & 84 & 56 & 2 & 248 \\
\hline & 0.8 & 12.1 & 23.4 & 5.2 & 1.2 & 0.0 & 33.9 & 22.6 & 0.8 & 100 \\
\hline \multirow{2}{*}{ Total } & 2907 & 977 & 818 & 787 & 687 & 150 & 106 & 75 & 97 & 6604 \\
\hline & 44.0 & 14.8 & 12.4 & 11.9 & 10.4 & 2.3 & 1.6 & 1.1 & 1.5 & 100 \\
\hline
\end{tabular}


Table 35: Russia: Multinational Federation ( 1993 -) Census 2002 Ia

\begin{tabular}{|c|c|c|c|c|c|c|}
\hline $\begin{array}{l}\text { Fearon }(2002) \\
\text { Elkins and Sides }(2006)^{a}\end{array}$ & $\begin{array}{c}\text { Russians } \\
0.81\end{array}$ & $\begin{array}{c}\text { Tatars } \\
0.04 \\
3.8 \text { (wvs: } 4.7 \text { ) }\end{array}$ & $\begin{array}{l}\text { Ukrainians } \\
0.03\end{array}$ & Bashkirs & $\begin{array}{c}\text { Chuvash } \\
0.01\end{array}$ & Chechens \\
\hline Group concentration $^{b}$ & & 2 & & & & $0.6(3)$ \\
\hline Unit & $\%$ & $\%$ & $\%$ & $\%$ & $\%$ & $\%$ \\
\hline & $\mathrm{n}$ & $\mathrm{n}$ & $\mathrm{n}$ & $\mathrm{n}$ & $\mathrm{n}$ & $\mathrm{n}$ \\
\hline Amur region & 92.0 & 0.5 & 3.5 & 0.1 & 0.1 & 0 \\
\hline & $831^{\prime} 004$ & $4^{\prime} 889$ & $31^{\prime} 475$ & 1'183 & 1'206 & 196 \\
\hline Arkhangelsk region & 94.2 & 0.2 & 2.1 & 0 & 0.1 & 0 \\
\hline & 1'258'938 & 3'283 & $27^{\prime} 841$ & 474 & $1^{\prime} 874$ & 354 \\
\hline Astrakhan region & 69.7 & 7 & 1.3 & 0.1 & 0.1 & 1 \\
\hline & $700^{\prime} 561$ & $70 ’ 590$ & $12^{\prime} 605$ & 614 & 1'171 & $10 ’ 019$ \\
\hline Belgorod region & 92.9 & 0.2 & 3.8 & 0 & 0 & 0 \\
\hline & 1'403'977 & 3'391 & $57^{\prime} 846$ & 314 & 718 & 261 \\
\hline Bryansk region & 96.3 & 0.1 & 1.5 & 0 & 0 & 0 \\
\hline & 1'328'448 & $1 ' 173$ & $20 ' 214$ & 151 & 355 & 273 \\
\hline Chelyabinsk region & 82.3 & 5.7 & 2.1 & 4.6 & 0.3 & 0 \\
\hline & $2^{\prime} 965 ' 885$ & $205 ’ 087$ & 76'994 & $166 ’ 372$ & 9'483 & $1 ' 249$ \\
\hline Chita region & 89.8 & 0.7 & 1 & 0.1 & 0.1 & 0 \\
\hline & 1'037'502 & 8'159 & $11^{\prime} 843$ & 1,228 & $1 ' 271$ & 226 \\
\hline Irkutsk region & 89.9 & 1.2 & 2.1 & 0.1 & 0.3 & 0 \\
\hline & 2'320'493 & $31 ' 068$ & $53^{\prime} 631$ & $2^{\prime} 451$ & $7 ’ 295$ & 712 \\
\hline Ivanovo region & 93.7 & 0.7 & 0.9 & 0 & 0.1 & 0.1 \\
\hline & $1^{\prime} 075^{\prime} 815$ & 8'205 & $10^{\prime} 629$ & 490 & $1^{\prime} 648$ & 633 \\
\hline Kaliningrad region & 82.4 & 0.5 & 4.9 & 0.1 & 0.2 & 0.1 \\
\hline & $786^{\prime} 885$ & $4 \cdot 729$ & $47^{\prime} 229$ & 562 & $2^{\prime} 027$ & 738 \\
\hline Kaluga region & 93.5 & 0.4 & 2.2 & 0 & 0.1 & 0 \\
\hline & $973 ’ 589$ & $4 ' 299$ & 23 ' 162 & 451 & $1 ’ 108$ & 466 \\
\hline Kamchatka region & 80.9 & 1 & 5.8 & 0.2 & 0.4 & 0 \\
\hline & 290 '108 & $3^{\prime} 617$ & $20 ' 870$ & 575 & 1'292 & 147 \\
\hline Kemerovo region & 91.9 & 1.8 & 1.3 & 0.1 & 0.5 & 0.1 \\
\hline & 2'664'816 & 51,030 & $37^{\prime} 622$ & 3'161 & $15^{\prime} 480$ & $1 ' 480$ \\
\hline Kirov region & 90.8 & 2.9 & 0.8 & 0 & 0.1 & 0 \\
\hline & $1^{\prime} 365^{\prime} 438$ & $43^{\prime} 415$ & $11 ' 399$ & 510 & 1'856 & 350 \\
\hline Kostroma region & 95.6 & 0.4 & 1.1 & 0 & 0.1 & 0.1 \\
\hline & $704 ' 049$ & 2'731 & 8'011 & 203 & 943 & 467 \\
\hline Kurgan region & 91.5 & 2 & 1.1 & 1.5 & 0.2 & 0.1 \\
\hline & $932^{\prime} 613$ & $20 ' 899$ & $11^{\prime} 243$ & $15^{\prime} 343$ & $1 ' 912$ & 1'041 \\
\hline Kursk region & 95.9 & 0.1 & 1.7 & 0 & 0 & 0 \\
\hline & 1'184'049 & $1^{\prime} 576$ & $20 ' 920$ & 177 & 368 & 360 \\
\hline Leningrad region & 89.6 & 0.6 & 2.5 & 0.1 & 0.2 & 0 \\
\hline & 1'495'295 & $9^{\prime} 432$ & 41,842 & 1'102 & $2^{\prime} 817$ & 542 \\
\hline Lipetsk region & 95.8 & 0.1 & 1.1 & 0 & 0 & 0 \\
\hline & 1'162'878 & 1'751 & $13^{\prime} 350$ & 214 & 400 & 468 \\
\hline Magadan region & 80.2 & 1.1 & 9.9 & 0.2 & 0.2 & 0 \\
\hline & $146^{\prime} 511$ & 2’006 & $18^{\prime} 068$ & 344 & 357 & 52 \\
\hline Moscow region & 91 & 0.8 & 2.2 & 0.1 & 0.2 & 0 \\
\hline & 6’022'763 & 52,851 & $147^{\prime} 808$ & 3’565 & $12 ' 530$ & 1'941 \\
\hline Murmansk region & 85.2 & 0.9 & 6.4 & 0.1 & 0.3 & 0 \\
\hline & $760 ' 862$ & $7^{\prime} 944$ & 56,845 & 1'162 & $2^{\prime} 759$ & 210 \\
\hline Nizhnij Novgorod region & 95 & 1.4 & 0.7 & 0 & 0.3 & 0 \\
\hline & 3'346'398 & $50 ' 609$ & $24 \cdot 241$ & 900 & $11 ' 364$ & 329 \\
\hline Novgorod region & 93.9 & 0.3 & 1.5 & 0 & 0.1 & 0.2 \\
\hline & $652 ' 165$ & $2^{\prime} 080$ & $10 ' 449$ & 253 & 728 & $1 ' 074$ \\
\hline Novosibirsk region & 93 & 1 & 1.3 & 0 & 0.2 & 0 \\
\hline & $2^{\prime} 504 ' 147$ & $27^{\prime} 874$ & $33 ' 793$ & 1'104 & $4 \cdot 147$ & 459 \\
\hline Omsk region & 83.5 & 2.3 & 3.7 & 0.1 & 0.2 & 0.1 \\
\hline & 1'735'512 & $47^{\prime} 796$ & $77^{\prime} 884$ & 1'101 & 4'191 & 1'091 \\
\hline Orenburg region & 73.9 & 7.6 & 3.5 & 2.4 & 0.8 & 0.1 \\
\hline & 1'611'509 & $165 ’ 967$ & $76^{\prime} 921$ & $52^{\prime} 685$ & $17^{\prime} 211$ & 1'996 \\
\hline Oryol region & 95.3 & 0.2 & 1.3 & 0 & 0 & 0.2 \\
\hline & $820 ’ 024$ & $1^{\prime} 417$ & $11^{\prime} 212$ & 149 & 406 & $1^{\prime} 630$ \\
\hline Penza region & 86.4 & 6 & 0.9 & 0 & 0.5 & 0 \\
\hline & 1'254'680 & $86^{\prime} 805$ & $12{ }^{\prime} 421$ & 368 & 6'738 & 455 \\
\hline Pskov region & 94.3 & 0.2 & 1.6 & 0 & 0.1 & 0.1 \\
\hline & $717^{\prime} 101$ & 1'499 & $12 ' 471$ & 256 & 658 & 557 \\
\hline Rostov region & 89.3 & 0.4 & 2.7 & 0 & 0.1 & 0.4 \\
\hline & 3'934'835 & $17^{\prime} 866$ & $118^{\prime} 486$ & 1'142 & 3’017 & $15^{\prime} 469$ \\
\hline Ryazan region & 94.6 & 0.5 & 1 & 0 & 0.1 & 0 \\
\hline & 1'161'447 & $5 ’ 569$ & $12^{\prime} 671$ & 386 & $1^{\prime} 284$ & 504 \\
\hline Sakhalin region & 84.3 & 1.2 & 4 & 0.1 & 0.2 & 0 \\
\hline & 460778 & 6'830 & $21^{\prime} 831$ & 586 & 1'300 & 185 \\
\hline Samara region & 83.6 & 3.9 & 1.9 & 0.2 & 3.1 & 0 \\
\hline & 2'708'549 & $127^{\prime} 931$ & $60^{\prime} 727$ & $7^{\prime} 885$ & $101 ’ 358$ & 1'193 \\
\hline Saratov region & 85.9 & 2.2 & 2.5 & 0.1 & 0.6 & 0.3 \\
\hline & 2'293'129 & 57,577 & $67^{\prime} 257$ & 3'988 & $15 ’ 956$ & 8,515 \\
\hline Smolensk region & 93.4 & 0.2 & 1.7 & 0 & 0.1 & 0 \\
\hline & $980 ’ 073$ & $2^{\prime} 424$ & $17^{\prime} 362$ & 303 & 735 & 405 \\
\hline Sverdlovsk region & 89.2 & 3.7 & 1.2 & 0.8 & 0.3 & 0 \\
\hline & 4'002'974 & $168^{\prime} 143$ & $55^{\prime} 478$ & $37^{\prime} 296$ & $11^{\prime} 510$ & 920 \\
\hline Tambov region & 96.5 & 0.2 & 0.9 & 0 & 0 & 0.1 \\
\hline & 1'136'864 & $2 ' 730$ & $10 ' 809$ & 177 & 423 & 637 \\
\hline Tomsk region & 90.8 & 1.9 & 1.6 & 0.2 & 0.6 & 0.1 \\
\hline & $950 ' 222$ & $20 ' 145$ & $16^{\prime} 726$ & $1 ’ 953$ & 5,881 & 711 \\
\hline Tula region & 95.2 & 0.5 & 1.3 & 0 & 0.1 & 0 \\
\hline & 1'595'564 & 8'968 & $22 ' 260$ & 409 & $1^{\prime} 085$ & 469 \\
\hline Tver region & 92.5 & 0.5 & 1.5 & 0 & 0.2 & 0.2 \\
\hline & 1'361'006 & 6'717 & 28,563 & 499 & 3’057 & $2^{\prime} 724$ \\
\hline Tyumen region & 71.6 & 7.4 & 48.5 & 1.4 & 0.9 & 0.3 \\
\hline & $2^{\prime} 336^{\prime} 520$ & $242^{\prime} 325$ & $211^{\prime} 372$ & $46^{\prime} 575$ & $30 ' 205$ & $10 ' 623$ \\
\hline Ulyanovsk region & 72.6 & 12.2 & 1.1 & 0.1 & 8 & 0 \\
\hline & $1^{\prime} 004^{\prime} 588$ & $168^{\prime} 766$ & $15^{\prime} 588$ & $1^{\prime} 217$ & $111^{\prime} 316$ & 542 \\
\hline Vladimir region & 94.7 & 0.6 & 1.1 & 0 & 0.2 & 0 \\
\hline & 1'443'857 & $8^{\prime} 670$ & $16 \cdot 755$ & 724 & 2'334 & 354 \\
\hline
\end{tabular}

${ }^{a}$ While three WVS have been carried outin Russia (1990, 1995, and 1999), none gives detailed information on the ethnic groups. 
Table 36: Russia: Multinational Federation ( 1993 -) Census 2002 Continued Ib

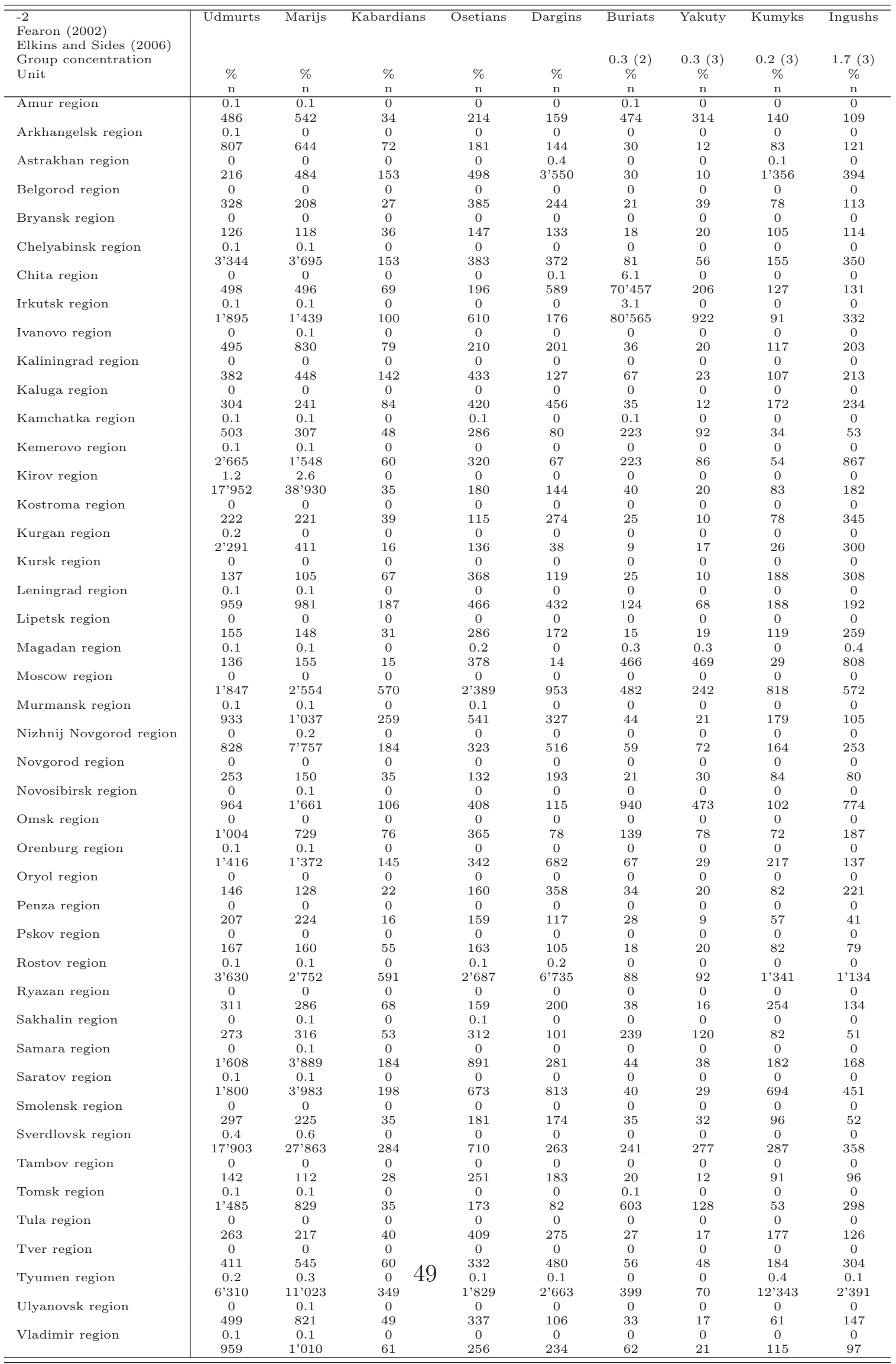


Table 37: Russia: Multinational Federation ( 1993 -) Census 2002 Continued Ic

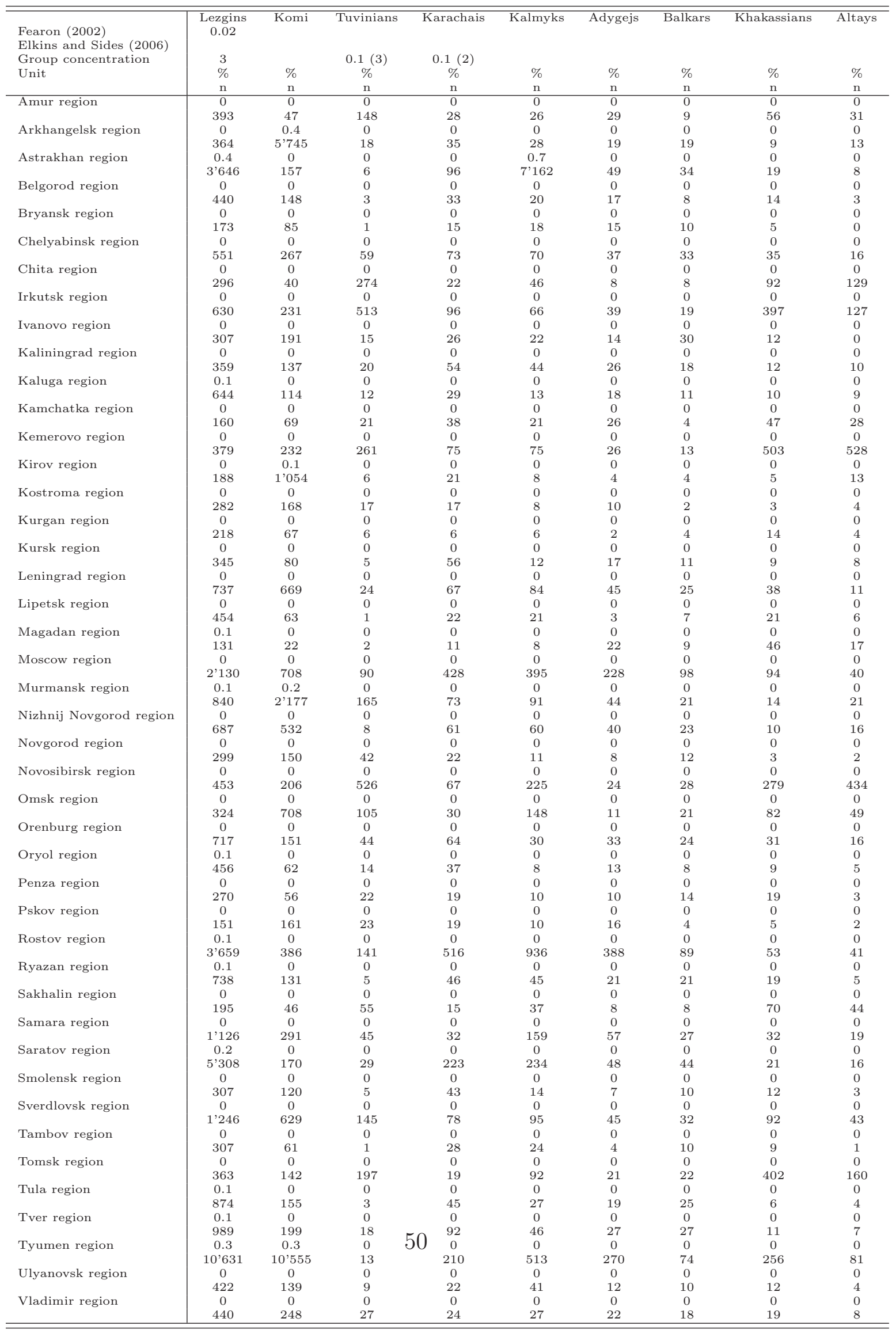


Table 38: Russia: Multinational Federation ( 1993 -) Census 2002 Continued Id

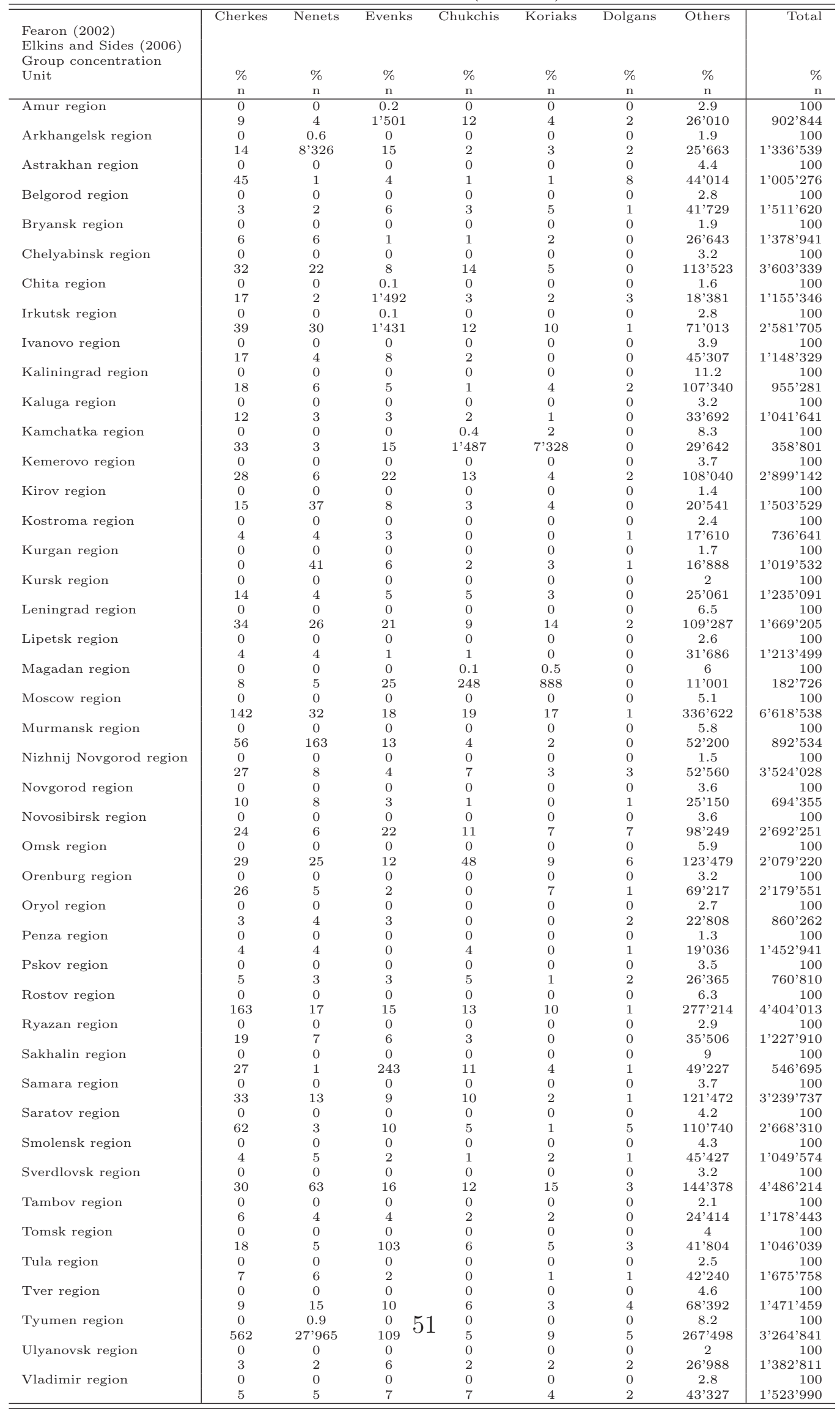


Table 39: Russia: Multinational Federation ( 1993 -) Census 2002 Second part of Russian Units IIa

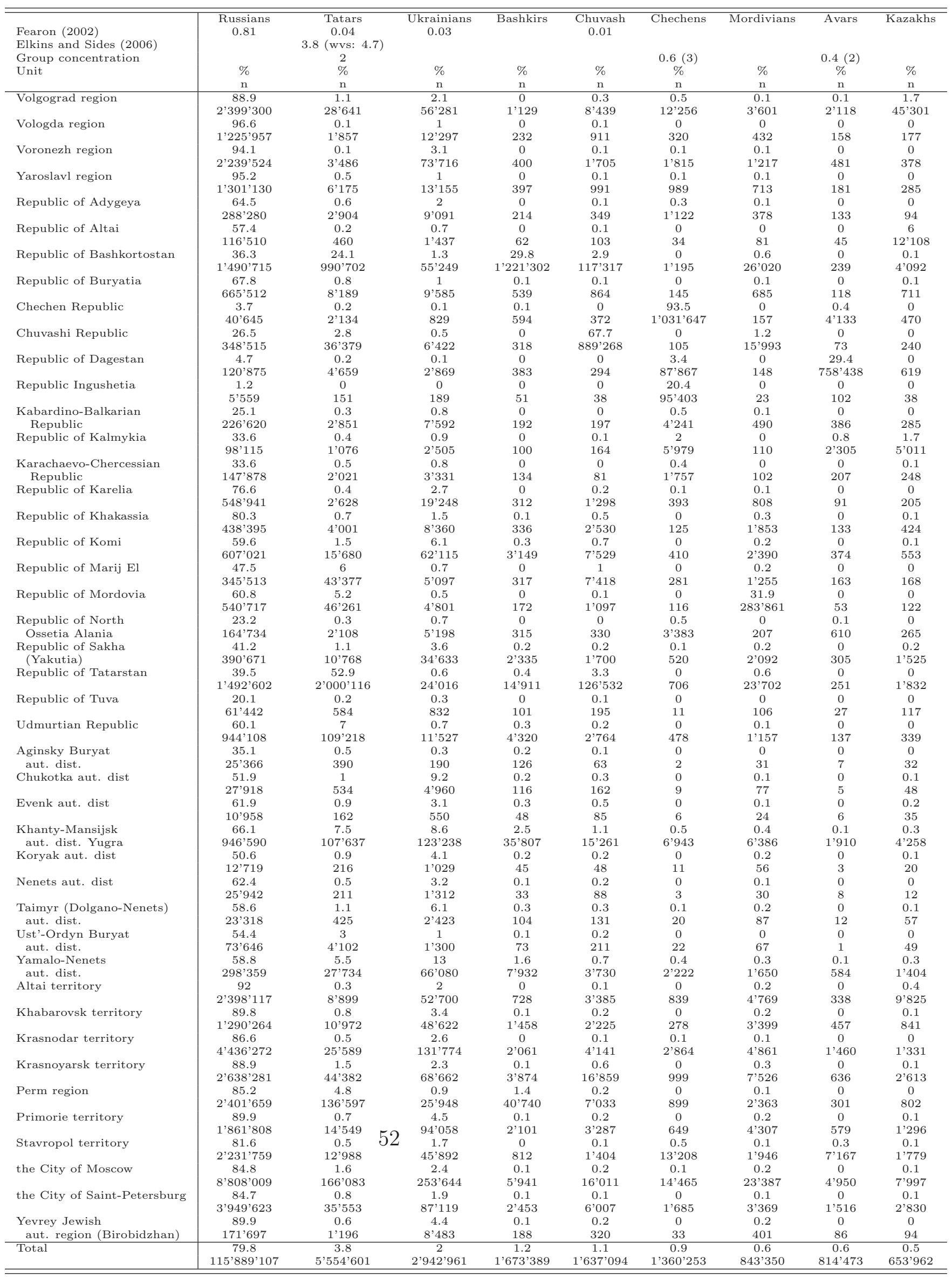


Table 40: Russia: Multinational Federation ( 1993 -) Census 2002 Second part of Russian Units Continued IIb

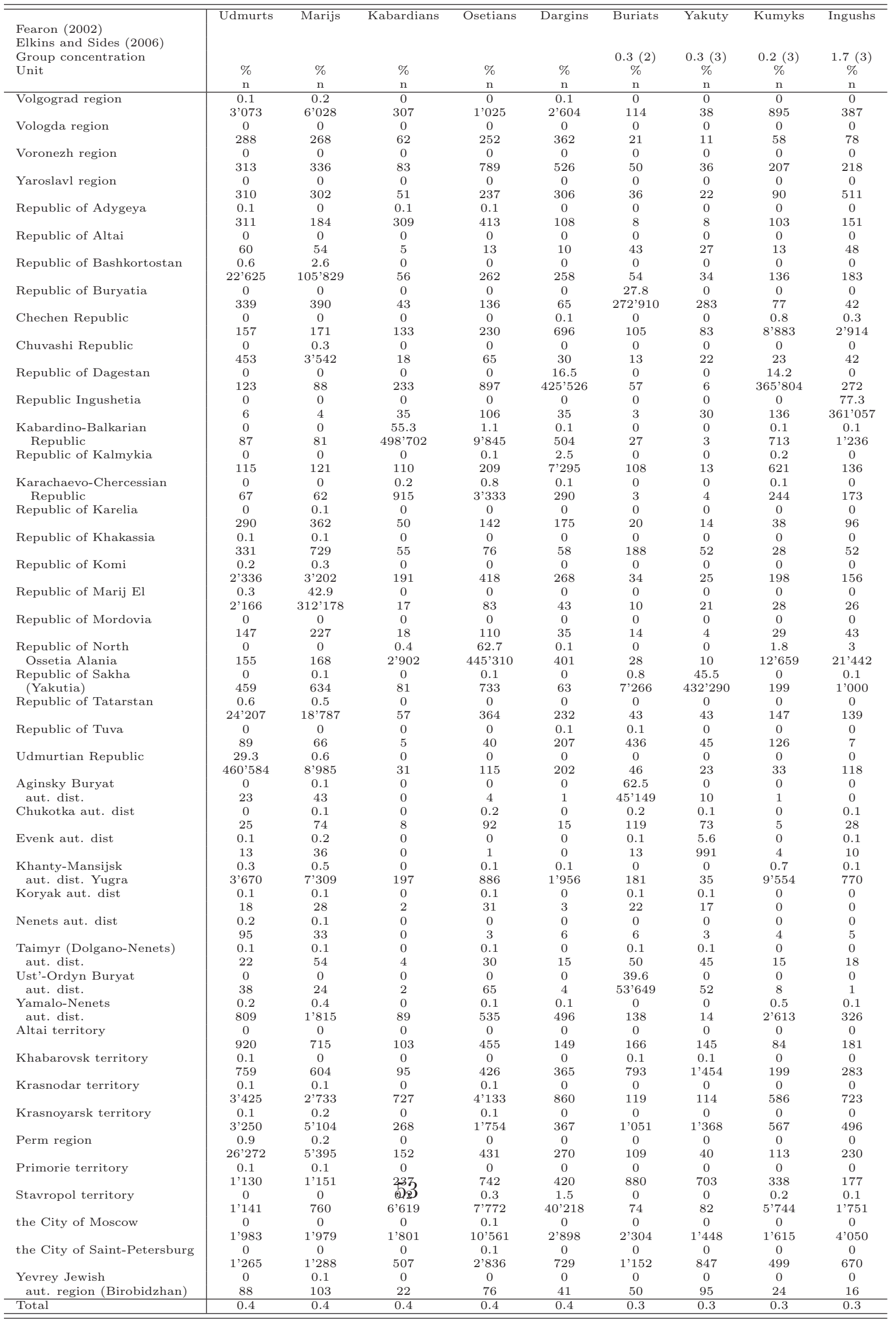


Table 41: Russia: Multinational Federation ( 1993 -) Census 2002 Second part of Russian Units Continued IIC

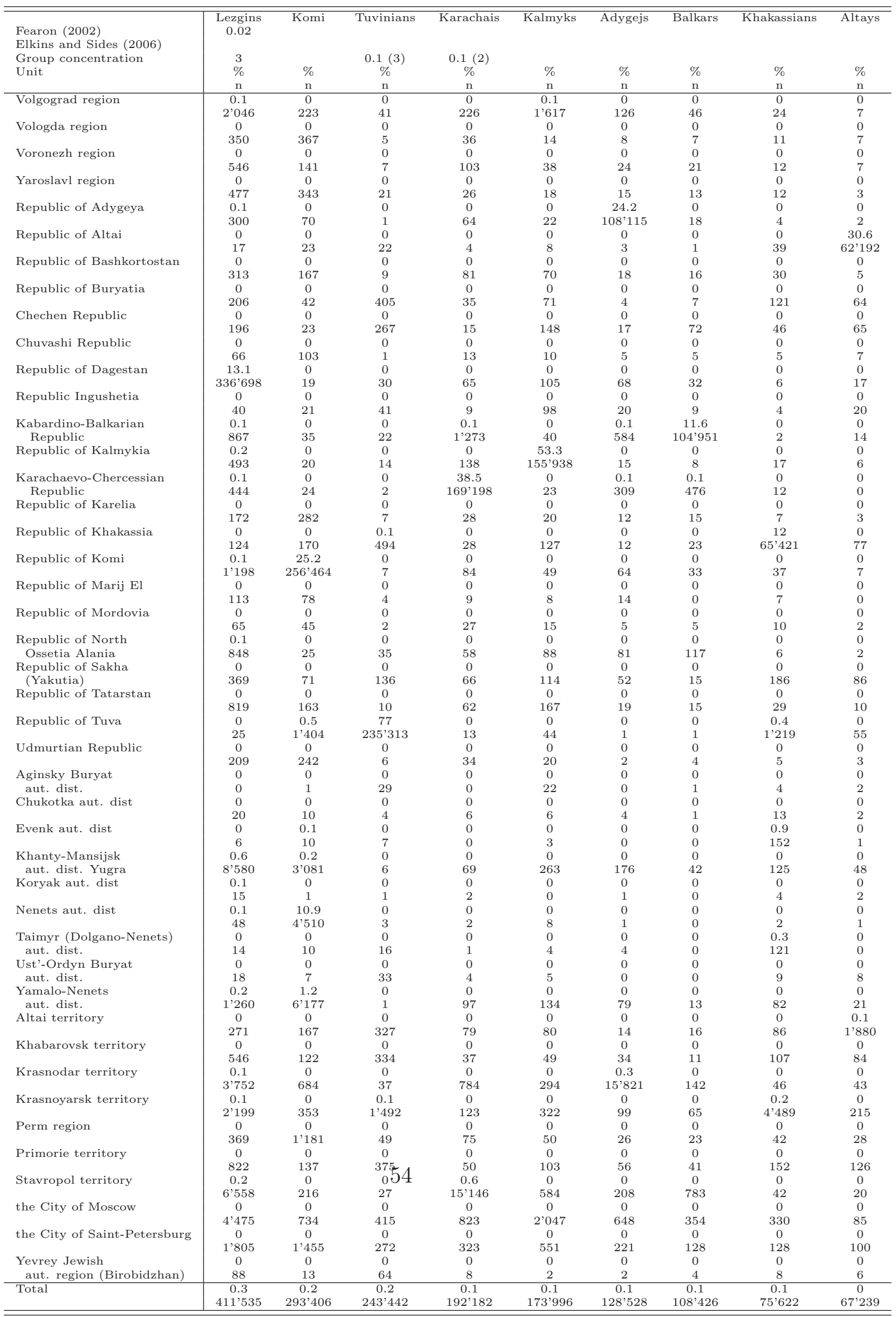


Table 42: Russia: Multinational Federation ( 1993 -) Census 2002 Second part of Russian Units Continued IIc

\begin{tabular}{|c|c|c|c|c|c|c|}
\hline $\begin{array}{l}\text { Fearon }(2002) \\
\text { Elkins and Sides (2006) } \\
\text { Group concentration } \\
\text { Unit }\end{array}$ & Cherkes & Nenets & Evenks & Chukchis & Koriaks & Dolgans \\
\hline & $\begin{array}{l}\% \\
\mathrm{n}\end{array}$ & $\begin{array}{l}\% \\
\mathrm{n}\end{array}$ & $\begin{array}{l}\% \\
\mathrm{n}\end{array}$ & $\begin{array}{l}\% \\
\mathrm{n}\end{array}$ & $\begin{array}{l}\% \\
\mathrm{n}\end{array}$ & $\begin{array}{l}\% \\
\mathrm{n}\end{array}$ \\
\hline Volgograd region & 0 & 0 & 0 & 0 & 0 & 0 \\
\hline & 79 & 9 & 8 & 6 & 0 & 0 \\
\hline Vologda region & 0 & 0 & 0 & 0 & 0 & 0 \\
\hline & 6 & 15 & 11 & 4 & 3 & 0 \\
\hline Voronezh region & 0 & 0 & 0 & 0 & 0 & 0 \\
\hline & 36 & 6 & 5 & 12 & 6 & 1 \\
\hline Yaroslavl region & 0 & 0 & 0 & 0 & 0 & 0 \\
\hline & 14 & 10 & 7 & 5 & 0 & 0 \\
\hline Republic of Adygeya & 0.1 & 0 & 0 & 0 & 0 & 0 \\
\hline & 642 & 1 & 3 & 2 & 1 & 0 \\
\hline Republic of Altai & 0 & 0 & 0 & 0 & 0 & 0 \\
\hline & 1 & 0 & 0 & 0 & 0 & 0 \\
\hline Republic of Bashkortostan & 0 & 0 & 0 & 0 & 0 & 0 \\
\hline & 22 & 4 & 7 & 11 & 4 & 1 \\
\hline Republic of Buryatia & 0 & 0 & 0.2 & 0 & 0 & 0 \\
\hline & 3 & 5 & $2^{\prime} 334$ & 7 & 0 & 8 \\
\hline Chechen Republic & 0 & 0 & 0 & 0 & 0 & 0 \\
\hline & 13 & 3 & 5 & 0 & 0 & 0 \\
\hline Chuvashi Republic & 0 & 0 & 0 & 0 & 0 & 0 \\
\hline & 6 & 2 & 2 & 12 & 0 & 0 \\
\hline Republic of Dagestan & 0 & 0 & 0 & 0 & 0 & 0 \\
\hline & 47 & 2 & 1 & 0 & 0 & 0 \\
\hline Republic Ingushetia & 0 & 0 & 0 & 0 & 0 & 0 \\
\hline & 26 & 0 & 1 & 0 & 0 & 0 \\
\hline Kabardino-Balkarian & 0.1 & 0 & 0 & 0 & 0 & 0 \\
\hline Republic & 725 & 0 & 0 & 0 & 1 & 0 \\
\hline Republic of Kalmykia & 0 & 0 & 0 & 0 & 0 & 0 \\
\hline & 56 & 22 & 6 & 4 & 0 & 1 \\
\hline Karachaevo-Chercessian & 11.3 & 0 & 0 & 0 & 0 & 0 \\
\hline Republic & $49 ' 591$ & 4 & 1 & 0 & 0 & 0 \\
\hline Republic of Karelia & 0 & 0 & 0 & 0 & 0 & 0 \\
\hline & 13 & 6 & 1 & 3 & 1 & 0 \\
\hline Republic of Khakassia & 0 & 0 & 0 & 0 & 0 & 0 \\
\hline & 15 & 0 & 21 & 2 & 3 & 7 \\
\hline Republic of Komi & 0 & 0.1 & 0 & 0 & 0 & 0 \\
\hline & 29 & 708 & 6 & 10 & 1 & 2 \\
\hline Republic of Marij El & 0 & 0 & 0 & 0 & 0 & 0 \\
\hline & 7 & 6 & 3 & 0 & 1 & 0 \\
\hline Republic of Mordovia & 0 & 0 & 0 & 0 & 0 & 0 \\
\hline & 3 & 0 & 2 & 1 & 0 & 0 \\
\hline Republic of North & 0 & 0 & 0 & 0 & 0 & 0 \\
\hline Ossetia Alania & 83 & 6 & 1 & 1 & 0 & 3 \\
\hline Republic of Sakha & 0 & 0 & 1.9 & 0.1 & 0 & 0.1 \\
\hline (Yakutia) & 64 & 27 & $18^{\prime} 232$ & 602 & 10 & $1^{\prime} 272$ \\
\hline Republic of Tatarstan & 0 & 0 & 0 & 0 & 0 & 0 \\
\hline & 14 & 3 & 10 & 7 & 4 & 2 \\
\hline Republic of Tuva & 0 & 0 & 0 & 0 & 0 & 0 \\
\hline & 29 & 0 & 7 & 0 & 0 & 0 \\
\hline Udmurtian Republic & 0 & 0 & 0 & 0 & 0 & 0 \\
\hline & 7 & 4 & 3 & 3 & 0 & 1 \\
\hline Aginsky Buryat & 0 & 0 & 0.2 & 0 & 0 & 0 \\
\hline aut. dist. & 1 & 0 & 164 & 0 & 0 & 0 \\
\hline Chukotka aut. dist & 0 & 0 & 0.1 & 23.5 & 0.1 & 0 \\
\hline & 1 & 19 & 37 & $12^{\prime} 622$ & 55 & 1 \\
\hline Evenk aut. dist & 0 & 0.1 & 21.5 & 0 & 0 & 0.2 \\
\hline & 1 & 12 & 3'802 & 0 & 0 & 30 \\
\hline Khanty-Mansijsk & 0 & 0.1 & 0 & 0 & 0 & 0 \\
\hline aut. dist. Yugra & 368 & $1^{\prime} 290$ & 43 & 1 & 6 & 1 \\
\hline Koryak aut. dist & 0 & 0 & 0 & 5.6 & 26.7 & 0 \\
\hline & 5 & 1 & 7 & $1^{\prime} 412$ & 6710 & 0 \\
\hline Nenets aut. dist & 0 & 18.7 & 0 & 0 & 0 & 0 \\
\hline & 2 & $7^{\prime} 754$ & 13 & 0 & 0 & 1 \\
\hline Taimyr (Dolgano-Nenets) & 0 & 7.7 & 0.8 & 0 & 0 & 13.9 \\
\hline aut. dist. & 6 & 3’054 & 305 & 1 & 0 & $5^{\prime} 517$ \\
\hline Ust'-Ordyn Buryat & 0 & 0 & 0 & 0 & 0 & 0 \\
\hline aut. dist. & 7 & 3 & 64 & 2 & 0 & 0 \\
\hline Yamalo-Nenets & 0 & 5.2 & 0 & 0 & 0 & 0 \\
\hline aut. dist. & 162 & $26^{\prime} 435$ & 57 & 3 & 1 & 4 \\
\hline Altai territory & 0 & 0 & 0 & 0 & 0 & 0 \\
\hline & 26 & 4 & 13 & 9 & 1 & 1 \\
\hline Khabarovsk territory & 0 & 0 & 0.3 & 0 & 0 & 0 \\
\hline & 26 & 12 & $4^{\prime} 533$ & 85 & 49 & 10 \\
\hline Krasnodar territory & 0.1 & 0 & 0 & 0 & 0 & 0 \\
\hline & $4 ' 446$ & 23 & 26 & 30 & 8 & 10 \\
\hline Krasnoyarsk territory & 0 & 0.1 & 0.2 & 0 & 0 & 0.2 \\
\hline & 67 & 3'188 & $4^{\prime} 632$ & 8 & 13 & 5'805 \\
\hline Perm region & 0 & 0 & 0 & 0 & 0 & 0 \\
\hline & 26 & 20 & 9 & 3 & 4 & 1 \\
\hline Primorie territory & 0 & 0 & 0 & 0 & 0 & 0 \\
\hline & 26 & 12 & 103 & 54 & 20 & 4 \\
\hline Stavropol territory & 0.1 & 0 & 055 & 0 & 0 & 0 \\
\hline & 2’097 & 14 & 9 & 5 & 7 & 1 \\
\hline the City of Moscow & 0 & 0 & 0 & 0 & 0 & 0 \\
\hline & 520 & 66 & 74 & 138 & 88 & 14 \\
\hline the City of Saint-Petersburg & 0 & 0 & 0 & 0 & 0 & 0 \\
\hline & 115 & 192 & 140 & 102 & 68 & 38 \\
\hline Yevrey Jewish & 0 & 0 & 0 & 0 & 0 & 0 \\
\hline aut. region (Birobidzhan) & 10 & 4 & 72 & 16 & 8 & 0 \\
\hline Total & 0 & 0 & 0 & 0 & 0 & 0 \\
\hline & $60^{\prime} 517$ & $41^{\prime} 302$ & $355^{\prime} 27$ & $15^{\prime} 767$ & $8^{\prime} 743$ & $7^{\prime} 261$ \\
\hline
\end{tabular}




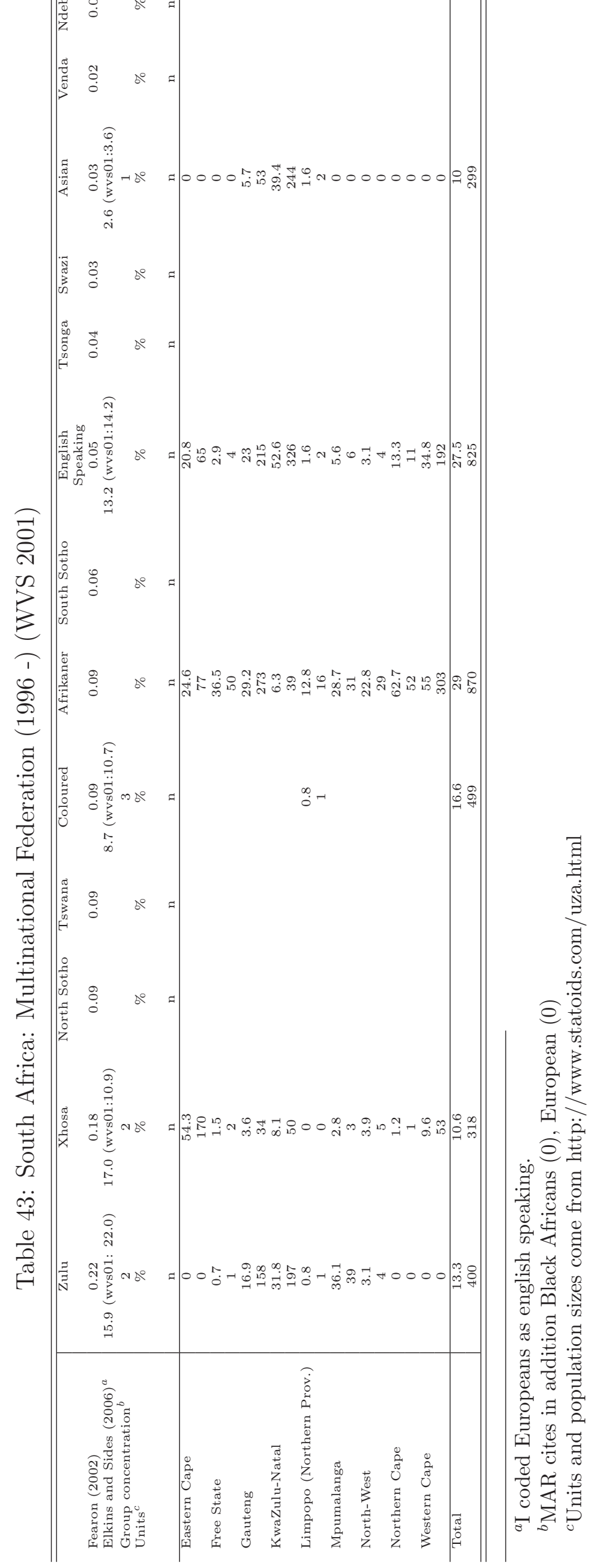


Table 44: South Africa: Multinational Federations (1996 -) Census 2001 on population groups ${ }^{b}$

\begin{tabular}{l|cccc|r}
\hline \hline & Black African & Coloured & Indian/Asian & White & Total \\
Units & $\%$ & $\%$ & $\%$ & $\%$ & $n$ \\
\hline Eastern Cape & $\mathrm{n}$ & $\mathrm{n}$ & $\mathrm{n}$ & $\mathrm{n}$ & $\mathrm{n}$ \\
& 87.5 & 7.4 & 0.3 & 4.7 & 14.4 \\
Free State & $5^{\prime} 635^{\prime} 080$ & $478^{\prime} 805$ & $18^{\prime} 372$ & $304^{\prime} 504$ & $6^{\prime} 436^{\prime} 761$ \\
& 88 & 3.1 & 0.1 & 8.8 & 6 \\
Gauteng & $2^{\prime} 381^{\prime} 072$ & $83^{\prime} 192$ & $3^{\prime} 721$ & $238^{\prime} 791$ & $2^{\prime} 706^{\prime} 776$ \\
& 73.8 & 3.8 & 2.5 & 19.9 & 19.7 \\
KwaZulu-Natal & $6^{\prime} 522^{\prime} 789$ & $337^{\prime} 974$ & $218^{\prime} 013$ & $1^{\prime} 758^{\prime} 396$ & $8^{\prime} 837^{\prime} 172$ \\
& 84.9 & 1.5 & 8.5 & 5.1 & 21 \\
Limpopo & $8^{\prime} 002^{\prime} 409$ & $141^{\prime} 888$ & $798^{\prime} 274$ & $483^{\prime} 448$ & $9^{\prime} 426^{\prime} 019$ \\
& 97.3 & 0.2 & 0.2 & 2.4 & 11.8 \\
Mpumalanga & $5^{\prime} 128^{\prime} 614$ & $10^{\prime} 162$ & $8^{\prime} 585$ & $126^{\prime} 276$ & $5^{\prime} 273^{\prime} 637$ \\
& 92.4 & 0.7 & 0.4 & 6.5 & 7 \\
Northern Cape & $2^{\prime} 886^{\prime} 345$ & $22^{\prime} 161$ & $11^{\prime} 243$ & $203^{\prime} 245$ & $3^{\prime} 122^{\prime} 994$ \\
& 35.7 & 51.6 & 0.3 & 12.4 & 1.8 \\
North West & $293^{\prime} 976$ & $424^{\prime} 389$ & $2^{\prime} 321$ & $102^{\prime} 040$ & $822^{\prime} 726$ \\
& 91.5 & 1.6 & 0.3 & 6.7 & 8.2 \\
Western Cape & $3^{\prime} 358^{\prime} 450$ & $56^{\prime} 960$ & $9^{\prime} 904$ & $244^{\prime} 036$ & $3^{\prime} 669^{\prime} 350$ \\
& 26.7 & 53.9 & 1 & 18.4 & 10.1 \\
& $1^{\prime} 207^{\prime} 429$ & $2^{\prime} 438^{\prime} 976$ & $45^{\prime} 028$ & $832^{\prime} 902$ & $4^{\prime} 524^{\prime} 335$ \\
\hline Total & 79 & 8.9 & 2.5 & 9.6 & 100 \\
& $35^{\prime} 416^{\prime} 164$ & $3^{\prime} 994^{\prime} 507$ & $1^{\prime} 115^{\prime} 461$ & $4^{\prime} 293^{\prime} 638$ & $44^{\prime} 819^{\prime} 770$ \\
\hline \hline
\end{tabular}

${ }^{a}$ Census 2001 by Province and Population group: http://www.statssa.gov.za/extract.htm ${ }^{b}$ Census 2001 by Province and Population group: http://www.statssa.gov.za/extract.htm 


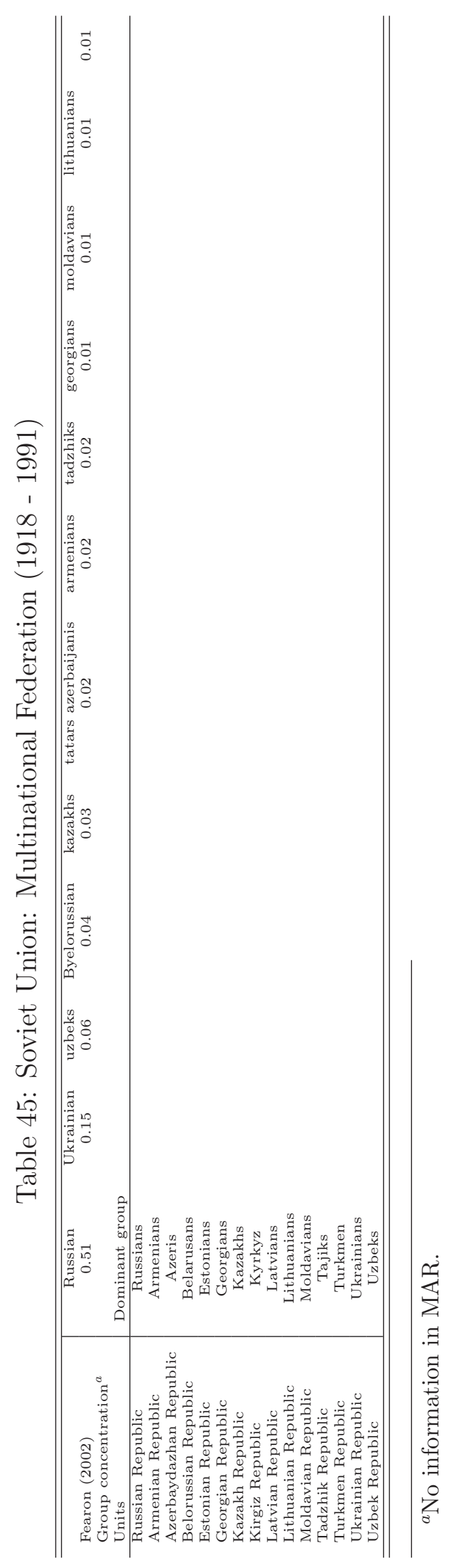


Table 46: Switzerland: Multinational Federations (1848 -) Census $2000^{a}$

\begin{tabular}{|c|c|c|c|c|c|c|c|c|c|c|}
\hline $\begin{array}{l}\text { Fearon }(2002) \\
\text { Elkins and Sides }(2006)^{b} \\
\text { Group concentration }\end{array}$ & $\begin{array}{c}\text { German } \\
0.62\end{array}$ & $\begin{array}{c}\text { French } \\
0.16\end{array}$ & $\begin{array}{c}\text { Italians } \\
0.08\end{array}$ & $\begin{array}{c}\text { Romansch } \\
0.05\end{array}$ & $\begin{array}{c}\text { Yugoslavs } \\
0.01\end{array}$ & $\begin{array}{c}\text { Spanish } \\
0.03\end{array}$ & $\begin{array}{c}\text { Portuguese } \\
0.02\end{array}$ & $\begin{array}{l}\text { Turks } \\
0.01\end{array}$ & $\begin{array}{c}\text { Asians } \\
0.01\end{array}$ & \\
\hline $\begin{array}{l}\mathrm{n} \\
\%\end{array}$ & $\begin{array}{c}\mathrm{n} \\
\% \\
\text { German }\end{array}$ & $\begin{array}{c}\mathrm{n} \\
\% \\
\text { French }\end{array}$ & $\begin{array}{c}\mathrm{n} \\
\% \\
\text { Italians }\end{array}$ & $\begin{array}{c}\mathrm{n} \\
\% \\
\text { Romansch }\end{array}$ & $\begin{array}{c}\mathrm{n} \\
\% \\
\text { Ex-Yugoslavs }\end{array}$ & $\begin{array}{c}\mathrm{n} \\
\% \\
\text { Spanish }\end{array}$ & $\begin{array}{c}\mathrm{n} \\
\% \\
\text { Portuguese }\end{array}$ & $\begin{array}{c}\mathrm{n} \\
\% \\
\text { Albanese }\end{array}$ & $\begin{array}{c}\mathrm{n} \\
\% \\
\text { Turks }\end{array}$ & $\begin{array}{c}\mathrm{n} \\
\% \\
\text { Other }\end{array}$ \\
\hline Aargau & $477 \times 093$ & $4 ' 151$ & 17,847 & 618 & $11^{\prime} 586$ & 3.287 & $3 \cdot 615$ & 9,823 & 5,709 & 13 '764 \\
\hline Appenzell A-Rhoden & $\begin{array}{c}87.1 \\
48^{\prime} 810\end{array}$ & $\begin{array}{l}0.8 \\
187\end{array}$ & $\begin{array}{l}3.3 \\
905\end{array}$ & $\begin{array}{l}0.1 \\
75\end{array}$ & $\begin{array}{c}2.1 \\
1^{\prime} 266\end{array}$ & $\begin{array}{c}0.6 \\
396\end{array}$ & $\begin{array}{l}0.7 \\
272\end{array}$ & $\begin{array}{l}1.8 \\
401\end{array}$ & $\begin{array}{l}1.0 \\
299\end{array}$ & $\begin{array}{l}2.5 \\
893\end{array}$ \\
\hline Appenzell I-Rhoden & $\begin{array}{c}91.2 \\
13,586\end{array}$ & $\begin{array}{l}0.3 \\
31\end{array}$ & $\begin{array}{l}1.7 \\
134\end{array}$ & $\begin{array}{l}0.1 \\
11\end{array}$ & $\begin{array}{l}2.4 \\
376\end{array}$ & $\begin{array}{l}0.7 \\
84\end{array}$ & $\begin{array}{l}0.5 \\
44\end{array}$ & $\begin{array}{l}0.7 \\
153\end{array}$ & $\begin{array}{l}0.6 \\
56\end{array}$ & $\begin{array}{l}1.7 \\
143\end{array}$ \\
\hline Basel-Landschaft & $\begin{array}{c}92.9 \\
226^{\prime} 275\end{array}$ & $\begin{array}{c}0.2 \\
3,822\end{array}$ & $\begin{array}{c}0.9 \\
8 ' 979\end{array}$ & $\begin{array}{l}0.1 \\
214\end{array}$ & $\begin{array}{c}2.6 \\
2 ’ 998\end{array}$ & $\begin{array}{c}0.6 \\
2^{\prime} 047\end{array}$ & $\begin{array}{c}0.3 \\
1 ' 052\end{array}$ & $\begin{array}{c}1.0 \\
2,562\end{array}$ & $\begin{array}{c}0.4 \\
2^{\prime} 931\end{array}$ & $\begin{array}{c}1.0 \\
8^{\prime} 494\end{array}$ \\
\hline Basel-Stadt & $\begin{array}{c}87.2 \\
149 ' 192\end{array}$ & $\begin{array}{c}1.5 \\
4^{\prime} 658\end{array}$ & $\begin{array}{c}3.5 \\
9^{\prime} 409\end{array}$ & $\begin{array}{l}0.1 \\
231\end{array}$ & $\begin{array}{c}1.2 \\
3,854\end{array}$ & $\begin{array}{c}0.8 \\
3,881\end{array}$ & $\begin{array}{c}0.4 \\
1,502\end{array}$ & $\begin{array}{c}1.0 \\
2 ' 443\end{array}$ & $\begin{array}{c}1.1 \\
4^{\prime} 086\end{array}$ & $\begin{array}{c}3.3 \\
8^{\prime} 823\end{array}$ \\
\hline \multirow[t]{2}{*}{ Bern } & $\begin{array}{c}79.3 \\
804 ' 190\end{array}$ & $\begin{array}{c}2.5 \\
72^{\prime} 646\end{array}$ & $\begin{array}{c}5.0 \\
18^{\prime} 908\end{array}$ & $\begin{array}{l}0.1 \\
688\end{array}$ & $\begin{array}{c}2.0 \\
8^{\prime} 539\end{array}$ & $\begin{array}{c}2.1 \\
8^{\prime} 220\end{array}$ & $\begin{array}{c}0.8 \\
6 ’ 052\end{array}$ & $\begin{array}{c}1.3 \\
9 ' 092\end{array}$ & $\begin{array}{c}2.2 \\
3^{\prime} 344\end{array}$ & $\begin{array}{c}4.7 \\
25^{\prime} 518\end{array}$ \\
\hline & 84.0 & 7.6 & 2.0 & 0.1 & 0.9 & 0.9 & 0.6 & 0.9 & 0.3 & 2.7 \\
\hline Fribourg & $\begin{array}{c}70^{\prime} 611 \\
29.2\end{array}$ & $\begin{array}{c}152^{\prime} 766 \\
63.2\end{array}$ & $3 ' 100$ & $\begin{array}{l}131 \\
0.1\end{array}$ & $\begin{array}{c}1 ' 252 \\
0.5\end{array}$ & $\begin{array}{c}1 ' 731 \\
0.7\end{array}$ & $\begin{array}{c}4.320 \\
1.8\end{array}$ & $\begin{array}{c}2^{\prime} 442 \\
1.0\end{array}$ & $\begin{array}{l}768 \\
0.3\end{array}$ & $\begin{array}{c}4,585 \\
1.9\end{array}$ \\
\hline Geneva & $\begin{array}{c}16,259 \\
3.9\end{array}$ & $\begin{array}{c}313 ' 485 \\
75.8\end{array}$ & $\begin{array}{l}15,191 \\
3.7\end{array}$ & $\begin{array}{l}229 \\
0.1\end{array}$ & $\begin{array}{c}2 \times 095 \\
0.5\end{array}$ & $\begin{array}{c}13^{\prime} 631 \\
3.3\end{array}$ & $\begin{array}{c}14^{\prime} 365 \\
3.5\end{array}$ & $\begin{array}{l}2,809 \\
0.7\end{array}$ & $\begin{array}{c}1,000 \\
0.2\end{array}$ & $\begin{array}{c}34^{\prime} 609 \\
8.4\end{array}$ \\
\hline \multirow[t]{2}{*}{ Graubunden } & $127^{\prime} 755$ & 961 & $\begin{array}{c}4.4 \\
19 ' 106\end{array}$ & $27^{\prime} 038$ & 3'152 & 852 & 3’099 & $1^{\prime} 277$ & $\begin{array}{l}1.4 \\
370\end{array}$ & 3'448 \\
\hline & 68.3 & 0.5 & 10.2 & 14.5 & 1.7 & 0.5 & 1.7 & 0.7 & 0.2 & 1.8 \\
\hline Jura & 3'001 & $61^{\prime} 376$ & $1 ' 210$ & 27 & 277 & 786 & 475 & 401 & 98 & 573 \\
\hline \multirow[t]{2}{*}{ Luzern } & $\begin{array}{c}4.4 \\
311,543\end{array}$ & $\begin{array}{c}90.0 \\
2^{\prime} 053\end{array}$ & $\begin{array}{c}1.8 \\
6^{\prime} 801\end{array}$ & $\begin{array}{r}0.0 \\
388\end{array}$ & $\begin{array}{c}0.4 \\
7^{\prime} 829\end{array}$ & $\begin{array}{c}1.2 \\
2^{\prime} 491\end{array}$ & $\begin{array}{c}0.7 \\
3 \prime 126\end{array}$ & $\begin{array}{c}0.6 \\
6,768\end{array}$ & $\begin{array}{l}0.1 \\
955\end{array}$ & $\begin{array}{c}0.8 \\
8^{\prime} 550\end{array}$ \\
\hline & 88.9 & 0.6 & 1.9 & 0.1 & 2.2 & 0.7 & 0.9 & 1.9 & 0.3 & 2.4 \\
\hline \multirow{2}{*}{ Neuchatel } & 6'849 & 143 '191 & $5^{\prime} 407$ & 95 & 956 & $1^{\prime} 860$ & 4'230 & 723 & 546 & 4'092 \\
\hline & 4.1 & 85.3 & 3.2 & 0.1 & 0.6 & 1.1 & 2.5 & 0.4 & 0.3 & 2.4 \\
\hline \multirow{2}{*}{ Nidwald } & $34^{\prime} 458$ & 229 & 533 & 48 & 487 & 145 & 272 & 361 & 16 & 686 \\
\hline & 92.5 & 0.6 & 1.4 & 0.1 & 1.3 & 0.4 & 0.7 & 1.0 & 0.0 & 1.8 \\
\hline \multirow{2}{*}{ Obwald } & $29^{\prime} 920$ & 144 & 329 & 32 & 456 & 95 & 370 & 452 & 95 & 534 \\
\hline & 92.3 & 0.4 & 1.0 & 0.1 & 1.4 & 0.3 & 1.1 & 1.4 & 0.3 & 1.6 \\
\hline \multirow{2}{*}{ Sankt Gallen } & $398^{\prime} 666$ & $1^{\prime} 813$ & $10^{\prime} 640$ & 845 & $12 ' 120$ & $2^{\prime} 910$ & $2^{\prime} 524$ & $10^{\prime} 388$ & $3^{\prime} 251$ & 9'680 \\
\hline & 88.0 & 0.4 & 2.3 & 0.2 & 2.7 & 0.6 & 0.6 & 2.3 & 0.7 & 2.1 \\
\hline \multirow{2}{*}{ Schaffhausen } & $64^{\prime} 323$ & 370 & $1^{\prime} 897$ & 80 & $2^{\prime} 008$ & 524 & 335 & $1^{\prime} 374$ & 686 & 1'795 \\
\hline & 87.6 & 0.5 & 2.6 & 0.1 & 2.7 & 0.7 & 0.5 & 1.9 & 0.9 & 2.4 \\
\hline \multirow{2}{*}{ Schwyz } & $115^{\prime} 688$ & 502 & $2^{\prime} 447$ & 234 & $2^{\prime} 864$ & 424 & 642 & $2^{\prime} 477$ & 533 & 2'893 \\
\hline & 89.9 & 0.4 & 1.9 & 0.2 & 2.2 & 0.3 & 0.5 & 1.9 & 0.4 & 2.2 \\
\hline \multirow[t]{2}{*}{ Solothurn } & 215,784 & $2^{\prime} 323$ & $7^{\prime} 678$ & 190 & 3'845 & 1'154 & 879 & 3'795 & 3'140 & 5,553 \\
\hline & 88.3 & 1.0 & 3.1 & 0.1 & 1.6 & 0.5 & 0.4 & 1.6 & 1.3 & 2.3 \\
\hline \multirow[t]{2}{*}{ Thurgau } & $202{ }^{\prime} 521$ & 948 & 6'317 & 287 & $3^{\prime} 588$ & $1^{\prime} 387$ & $2^{\prime} 480$ & $5 ' 136$ & $2 ’ 036$ & 4'175 \\
\hline & 88.5 & 0.4 & 2.8 & 0.1 & 1.6 & 0.6 & 1.1 & 2.2 & 0.9 & 1.8 \\
\hline & 93.5 & 0.2 & 1.3 & 0.1 & 2.0 & 0.2 & 0.4 & 0.6 & 0.7 & 1.0 \\
\hline Valais & $77^{\prime} 255$ & $171^{\prime} 129$ & $5^{\prime} 987$ & 114 & $2^{\prime} 800$ & $1^{\prime} 464$ & 6'233 & $2^{\prime} 513$ & 309 & 4,595 \\
\hline & 28.4 & 62.8 & 2.2 & 0.0 & 1.0 & 0.5 & 2.3 & 0.9 & 0.1 & 1.7 \\
\hline Vaud & $30 ' 408$ & $524{ }^{\prime} 234$ & $18^{\prime} 713$ & 268 & 6'070 & $10 ' 312$ & 15,494 & 5'551 & $1 ’ 596$ & $28^{\prime} 011$ \\
\hline & 4.7 & 81.8 & 2.9 & 0.0 & 0.9 & 1.6 & 2.4 & 0.9 & 0.2 & 4.4 \\
\hline Zug & $85^{\prime} 142$ & 1'138 & $2 ' 525$ & 156 & 2'891 & 689 & 968 & $1^{\prime} 146$ & 871 & $4^{\prime} 526$ \\
\hline & 85.1 & 1.1 & 2.5 & 0.2 & 2.9 & 0.7 & 1.0 & 1.1 & 0.9 & 4.5 \\
\hline Zurich & 1'040'168 & $17^{\prime} 685$ & $49^{\prime} 750$ & $2^{\prime} 606$ & $22 ' 694$ & $15^{\prime} 638$ & $13^{\prime} 256$ & $19 ' 983$ & $10 ’ 190$ & $55^{\prime} 936$ \\
\hline & 83.4 & 1.4 & 4.0 & 0.2 & 1.8 & 1.3 & 1.1 & 1.6 & 0.8 & 4.5 \\
\hline Total & $\begin{array}{c}4^{\prime} 640 ' 359 \\
63.7\end{array}$ & $\begin{array}{c}\text { 1'485'056 } \\
20.4\end{array}$ & $\begin{array}{c}470 ’ 961 \\
6.5\end{array}$ & $\begin{array}{c}35 ’ 095 \\
0.5\end{array}$ & $\begin{array}{c}111 ' 366 \\
1.5\end{array}$ & $\begin{array}{c}77^{\prime} 506 \\
1.1\end{array}$ & $\begin{array}{c}89.527 \\
1.2\end{array}$ & $\begin{array}{l}94 ' 937 \\
1.3\end{array}$ & $\begin{array}{c}44^{\prime} 523 \\
0.6\end{array}$ & $\begin{array}{c}238^{\prime} 680 \\
3.3\end{array}$ \\
\hline
\end{tabular}

${ }^{a}$ Bundesamt fuer Statistik; http://www.bfs.admin.ch/bfs/portal/fr/index/themen/bevoelkerung/sprachen__religio The WVS of 1996 also allow for estimating the ethnic make-up of the federal units and yield similar results.

${ }^{b}$ MAR cites Jurassians 2.2 (3) and foreign workers 18.4 (wvs96: 5.0) (0). 
Table 47: United States: National federation (1789 - ) Estimates $2004^{a}$

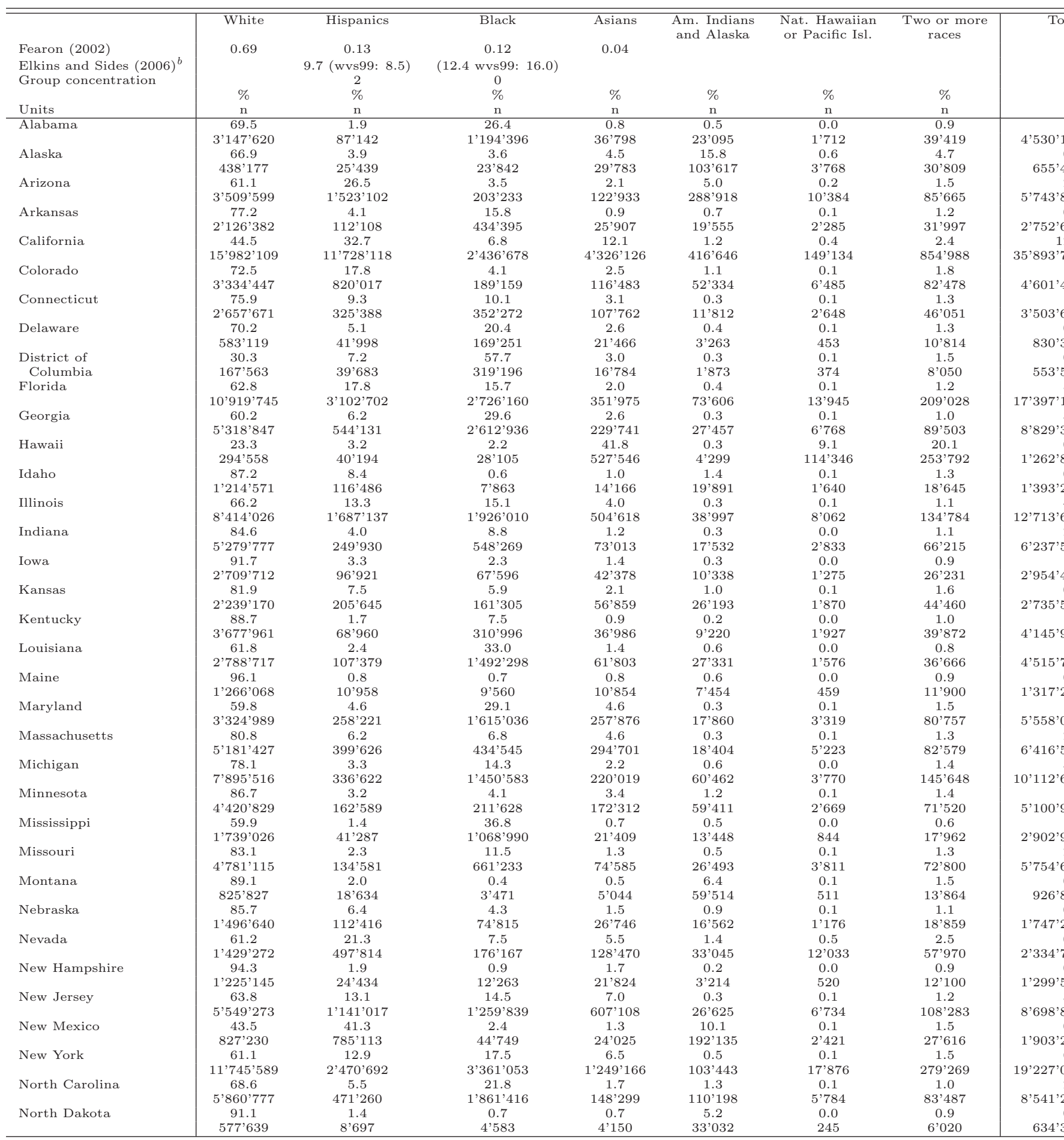

${ }^{a}$ Population Division, U.S. Census Bureau; Table 4: Annual Estimates of the Population by Race Alone and Hispanic or Latino Origin for the United States and States (SC-EST2004-04)

${ }^{b}$ While there are four WVS carried out in the United States (1982, 1990, 1995, and 1999), the information on residency only covered 9 regions and 1 state, instead of the 50 states. 
Table 48: United States Continued

\begin{tabular}{|c|c|c|c|c|c|c|c|c|}
\hline & White & Hispanics & Black & Asians & $\begin{array}{c}\text { Am. Indians } \\
\text { and Alaska }\end{array}$ & $\begin{array}{l}\text { Nat. Hawaiian } \\
\text { or Pacific Isl. }\end{array}$ & $\begin{array}{l}\text { Two or more } \\
\text { races }\end{array}$ & \\
\hline $\begin{array}{l}\text { Fearon }(2002) \\
\text { Flkins and Sides }(2006)\end{array}$ & 0.69 & $\begin{array}{c}0.13 \\
9.7(\text { vys } 99 \cdot 8.5)\end{array}$ & $\begin{array}{c}0.12 \\
(12.4 \text { wys99: } 16.0)\end{array}$ & 0.04 & & & & \\
\hline \multirow{2}{*}{ Group concentration } & & 2 & $\begin{array}{c}(12.20 \\
0\end{array}$ & & & & & \\
\hline & $\%$ & $\%$ & $\%$ & $\%$ & $\%$ & $\%$ & $\%$ & \\
\hline Units & $\mathrm{n}$ & $\mathrm{n}$ & $\mathrm{n}$ & $\mathrm{n}$ & $\mathrm{n}$ & $\mathrm{n}$ & $\mathrm{n}$ & \\
\hline \multirow[t]{2}{*}{ Ohio } & 83.3 & 1.9 & 11.9 & 1.4 & 0.2 & 0.0 & 1.2 & \\
\hline & 9'547'385 & $220 ’ 858$ & 1'362'446 & 159'094 & 26 '025 & 3'556 & $139^{\prime} 647$ & $11^{\prime}$ \\
\hline \multirow[t]{2}{*}{ Oklahoma } & 72.9 & 5.7 & 7.7 & 1.5 & 8.1 & 0.1 & 4.0 & \\
\hline & 2'569'827 & $200 ` 472$ & $272{ }^{\prime} 224$ & 53,846 & 283 ' 844 & 2'934 & $140 ' 406$ & 3,5 \\
\hline \multirow[t]{2}{*}{ Oregon } & 82.0 & 8.9 & 1.8 & 3.4 & 1.4 & 0.3 & 2.3 & \\
\hline & $2^{\prime} 948^{\prime} 024$ & $318^{\prime} 572$ & $64 ' 117$ & $121^{\prime} 880$ & $49^{\prime} 138$ & $9^{\prime} 630$ & $83^{\prime} 225$ & 3'59. \\
\hline \multirow[t]{2}{*}{ Pennsylvania } & 82.9 & 3.3 & 10.5 & 2.2 & 0.2 & 0.0 & 0.9 & \\
\hline & $10^{\prime} 288^{\prime} 227$ & $405^{\prime} 086$ & 1'304'439 & $266^{\prime} 757$ & $21^{\prime} 900$ & 5'203 & $114^{\prime} 680$ & $12^{\prime} 4$ \\
\hline \multirow[t]{2}{*}{ Rhode Island } & 80.5 & 8.5 & 6.1 & 2.7 & 0.6 & 0.1 & 1.5 & \\
\hline & $870^{\prime} 209$ & $92^{\prime} 228$ & $65^{\prime} 958$ & $28^{\prime} 763$ & 6'366 & 1'275 & $15^{\prime} 833$ & $1^{\prime}$ \\
\hline \multirow[t]{2}{*}{ South Carolina } & 65.6 & 2.7 & 29.4 & 1.1 & 0.4 & 0.1 & 0.8 & \\
\hline & 2'753'295 & $114^{\prime} 799$ & 1'232'732 & $44^{\prime} 385$ & $15^{\prime} 677$ & $2^{\prime} 283$ & $34 ' 897$ & $4^{\prime} 1$ \\
\hline \multirow[t]{2}{*}{ South Dakota } & 87.1 & 1.6 & 0.8 & 0.7 & 8.6 & 0.0 & 1.2 & \\
\hline & $671^{\prime} 072$ & $12{ }^{\prime} 696$ & 6’006 & $5 ’ 208$ & $66^{\prime} 535$ & 280 & $9^{\prime} 086$ & 77 \\
\hline \multirow[t]{2}{*}{ Tennessee } & 78.1 & 2.6 & 16.8 & 1.2 & 0.3 & 0.0 & 0.9 & \\
\hline & $4^{\prime} 610^{\prime} 827$ & $151^{\prime} 962$ & $991 ' 435$ & $71 ' 115$ & $17^{\prime} 005$ & 2'929 & 55,689 & 5 \\
\hline \multirow[t]{2}{*}{ Utah } & 83.8 & 10.0 & 0.9 & 1.9 & 1.3 & 0.7 & 1.3 & \\
\hline & $2^{\prime} 002^{\prime} 538$ & $238^{\prime} 534$ & $22^{\prime} 534$ & $44^{\prime} 608$ & $32 ' 191$ & $17^{\prime} 368$ & $31^{\prime} 266$ & $2 \%$ \\
\hline \multirow[t]{2}{*}{ Vermont } & 96.0 & 0.9 & 0.6 & 1.0 & 0.4 & 0.0 & 1.1 & \\
\hline & $596^{\prime} 514$ & 5,797 & 3'704 & 6'311 & $2^{\prime} 326$ & 166 & 6'576 & 62 \\
\hline \multirow[t]{2}{*}{ Virginia } & 68.7 & 5.1 & 19.9 & 4.4 & 0.3 & 0.1 & 1.5 & \\
\hline & 5'121'944 & $380^{\prime} 387$ & 1'482'963 & $329^{\prime} 529$ & $24^{\prime} 314$ & $5 ' 476$ & $115^{\prime} 214$ & $7^{\prime} 4$ \\
\hline \multirow[t]{2}{*}{ Washington } & 77.5 & 7.8 & 3.5 & 6.3 & 1.6 & 0.5 & 2.9 & \\
\hline & 4'808'520 & 481,498 & 216 ' 484 & $387^{\prime} 757$ & $101 ' 384$ & $28 ' 189$ & $179^{\prime} 956$ & $6 \%$ \\
\hline \multirow[t]{2}{*}{ West Virginia } & 94.4 & 0.7 & 3.2 & 0.6 & 0.2 & 0.0 & 0.8 & \\
\hline & $1^{\prime} 714^{\prime} 473$ & $13^{\prime} 320$ & $58^{\prime} 094$ & $10^{\prime} 238$ & 3'729 & 425 & $15^{\prime} 075$ & $1^{\prime} 81$ \\
\hline \multirow[t]{2}{*}{ Wisconsin } & 86.2 & 3.9 & 5.9 & 1.9 & 0.9 & 0.0 & 1.0 & \\
\hline & $4^{\prime} 748^{\prime} 917$ & $217^{\prime} 583$ & $327^{\prime} 626$ & $105^{\prime} 769$ & $51^{\prime} 463$ & $2 ' 156$ & $55^{\prime} 512$ & $5^{\prime} 5$ \\
\hline \multirow[t]{2}{*}{ Wyoming } & 88.6 & 6.2 & 0.9 & 0.6 & 2.4 & 0.1 & 1.2 & \\
\hline & $448^{\prime} 694$ & $31 ' 370$ & 4'448 & 3'255 & $12{ }^{\prime} 224$ & 358 & 6'180 & 00 \\
\hline Total & $\begin{array}{c}67.4 \\
197^{\prime} 8400^{\prime} 821\end{array}$ & $\begin{array}{c}13.0 \\
38^{\prime} 216^{\prime} 940\end{array}$ & $\begin{array}{c}12.8 \\
37^{\prime} 502^{\prime} 320\end{array}$ & $\begin{array}{c}4.2 \\
12^{\prime} 326^{\prime} 216\end{array}$ & $\begin{array}{c}1.0 \\
2^{\prime} 824^{\prime} 751\end{array}$ & $\begin{array}{c}0.2 \\
505,602\end{array}$ & $\begin{array}{c}1.5 \\
4^{\prime} 438^{\prime} 754\end{array}$ & $293^{\prime} 65$ \\
\hline
\end{tabular}


Table 49: Venezuela: National federation $\left(1960\right.$ - ) $\left(\right.$ WVS 2000) ${ }^{a}$

\begin{tabular}{|c|c|c|c|c|c|c|}
\hline $\begin{array}{l}\text { Fearon }(2002) \\
\text { Elkins and Sides (2006) } \\
\text { Group concentration }\end{array}$ & $\begin{array}{c}\text { Mestizo } \\
0.68\end{array}$ & $\begin{array}{c}\text { White } \\
0.21\end{array}$ & $\begin{array}{c}\text { Blacks } \\
0.10 \\
10.0 \text { (wvs00: 4.3) } \\
2 \\
\%\end{array}$ & $\begin{array}{c}\text { Indigenous } \\
0.01 \\
1.4 \text { (wvs00: } 0.5 \text { ) } \\
3 \\
\%\end{array}$ & Other & Indigenous $^{b}$ \\
\hline Units & $\mathrm{n}$ & $\mathrm{n}$ & $\mathrm{n}$ & $\mathrm{n}$ & $\mathrm{n}$ & $\mathrm{n}$ \\
\hline \multirow[t]{2}{*}{ Amazonas } & 70 & 10 & 0 & 20 & 0 & 22 \\
\hline & 7 & 1 & 0 & 2 & 0 & $70 ' 464$ \\
\hline Anzoategui & $\begin{array}{l}63 \\
34\end{array}$ & $\begin{array}{c}32.5 \\
19\end{array}$ & 1.9 & $\begin{array}{l}0 \\
0\end{array}$ & 0 & $\begin{array}{r}0.5 \\
1,222,225\end{array}$ \\
\hline \multirow[t]{2}{*}{ Apure } & 100 & 0 & 0 & 0 & 0 & 0.4 \\
\hline & 9 & 0 & 0 & 0 & 0 & $377^{\prime} 756$ \\
\hline Aragua & 67.3 & 29 & 3.7 & 0 & 0 & 0.2 \\
\hline \multirow[t]{2}{*}{ Barinas } & $\begin{array}{c}72 \\
86.3\end{array}$ & $\begin{array}{c}31 \\
13.6\end{array}$ & $\begin{array}{l}4 \\
0\end{array}$ & $\begin{array}{l}0 \\
0\end{array}$ & 0 & $\begin{array}{r}1 ' 449 ' 616 \\
0.3\end{array}$ \\
\hline & 19 & 3 & 0 & 0 & 0 & $624^{\prime} 508$ \\
\hline \multirow[t]{2}{*}{ Bolivar } & 68.4 & 25 & 6.6 & 0 & 0 & 0.8 \\
\hline & $\begin{array}{c}52 \\
48.3\end{array}$ & $\begin{array}{l}19 \\
49\end{array}$ & $\begin{array}{c}5 \\
2.7\end{array}$ & $\begin{array}{l}0 \\
0\end{array}$ & $\begin{array}{l}0 \\
0\end{array}$ & $\begin{array}{r}1^{\prime} 214^{\prime} 846 \\
0.2\end{array}$ \\
\hline Carabobo & $\begin{array}{c}40.5 \\
71\end{array}$ & $\begin{array}{l}49 \\
72\end{array}$ & $\begin{array}{c}2.1 \\
4\end{array}$ & 0 & 0 & 1'932'168 \\
\hline \multirow[t]{2}{*}{ Cojedes } & 44.4 & 55.6 & 0 & 0 & 0 & 0.2 \\
\hline & 4 & 5 & 0 & 0 & 0 & 253 '105 \\
\hline \multirow{2}{*}{ Delta Amacuro } & 30 & 60 & 0 & 1 & 0 & 4.9 \\
\hline & 3 & 6 & 0 & 10 & 0 & $97 ’ 987$ \\
\hline Dependencias Federales** & & & & & 0 & $\begin{array}{r}0.3 \\
1,651\end{array}$ \\
\hline \multirow{2}{*}{ Distrito Federal* } & 54.2 & 40.1 & 5.1 & 0.6 & 0 & 0.2 \\
\hline & 96 & 71 & 9 & 1 & 0 & 1'836'286 \\
\hline \multirow[t]{2}{*}{ Falcon } & 79.4 & 20.6 & 0 & 0 & 0 & 0.3 \\
\hline & 27 & 7 & 0 & 0 & 0 & 763 '188 \\
\hline \multirow[t]{2}{*}{ Guarico } & 88.9 & 0 & 11.1 & 0 & 0 & 0.3 \\
\hline & 8 & 0 & 1 & 0 & 0 & $627^{\prime} 086$ \\
\hline \multirow[t]{2}{*}{ Lara } & 76.7 & 23.4 & 0 & 0 & 0 & 0.1 \\
\hline & 59 & 18 & 0 & 0 & 0 & $1^{\prime} 556^{\prime} 415$ \\
\hline \multirow[t]{2}{*}{ Merida } & 47.4 & 52.6 & 0 & 0 & 0 & 0.3 \\
\hline & 9 & 10 & 0 & 0 & 0 & $715^{\prime} 268$ \\
\hline \multirow[t]{2}{*}{ Miranda } & 50.5 & 39.2 & 7.2 & 1 & 2.1 & 0.3 \\
\hline & 49 & 38 & 7 & 1 & 2 & 2'330'872 \\
\hline \multirow[t]{2}{*}{ Monagas } & 37.9 & 55.2 & 3.4 & 3.4 & 0 & 0.8 \\
\hline & 11 & 16 & 1 & 1 & 0 & $712^{\prime} 626$ \\
\hline \multirow[t]{2}{*}{ Nueva Esparta } & 63.2 & 31.6 & 5.3 & 0 & 0 & 1 \\
\hline & 12 & 6 & 1 & 0 & 0 & $373^{\prime} 851$ \\
\hline \multirow[t]{2}{*}{ Portuguesa } & 52.1 & 8.7 & 39.1 & 0 & 0 & 0.2 \\
\hline & 12 & $\begin{array}{c}0.1 \\
2\end{array}$ & 9 & 0 & 0 & $725^{\prime} 740$ \\
\hline \multirow[t]{2}{*}{ Sucre } & 57.2 & 32.1 & 10.7 & 0 & 0 & 1 \\
\hline & 16 & 9 & 3 & 0 & 0 & $786^{\prime} 483$ \\
\hline \multirow{2}{*}{ Tachira } & 52.7 & 44.4 & 2.8 & 0 & 0 & 0.2 \\
\hline & 19 & 16 & 1 & 0 & 0 & $992^{\prime} 669$ \\
\hline Trujillo & 88.9 & 11.1 & 0 & 0 & 0 & 0.2 \\
\hline & 8 & 1 & 0 & 0 & 0 & $608^{\prime} 563$ \\
\hline Vargas & 81.8 & 13.6 & 4.5 & 0 & 0 & 0.2 \\
\hline & 18 & 3 & 1 & 0 & 0 & $298 ' 109$ \\
\hline Yaracuy & 51.8 & 48.4 & 0 & 0 & 0 & 0.2 \\
\hline & 14 & 13 & 0 & 0 & 0 & $499^{\prime} 049$ \\
\hline Zulia & 54.7 & 42.7 & 2.7 & 0 & 0 & 8.9 \\
\hline & 82 & 64 & 4 & 0 & 0 & 2'983'679 \\
\hline Total & 59.3 & 35.8 & 4.3 & 0.5 & 0.2 & 1.5 \\
\hline & 711 & 430 & 51 & 6 & 2 & $23^{\prime} 054^{\prime} 210$ \\
\hline
\end{tabular}

${ }^{a}$ We also report the data from the census 2001 which provides statistics on Indigenous people in each unit.

${ }^{b}$ Census 2001; http://www.ine.gov.ve/censo/fichascenso/fichacenso.asp 


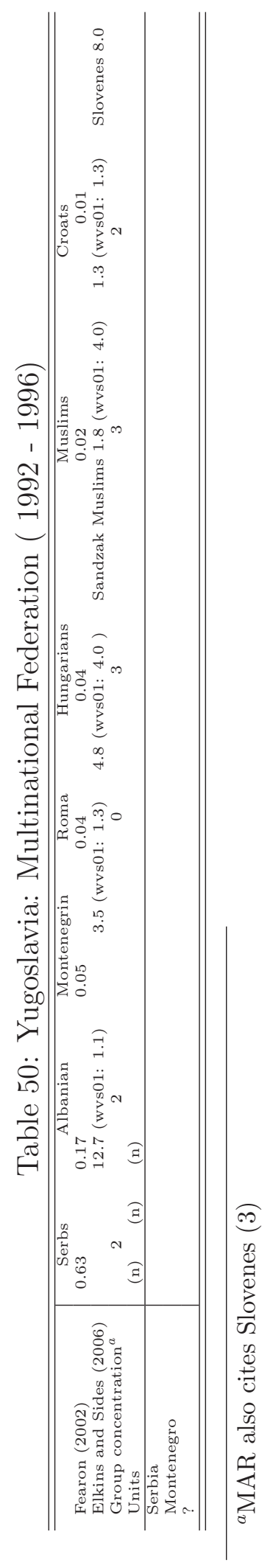




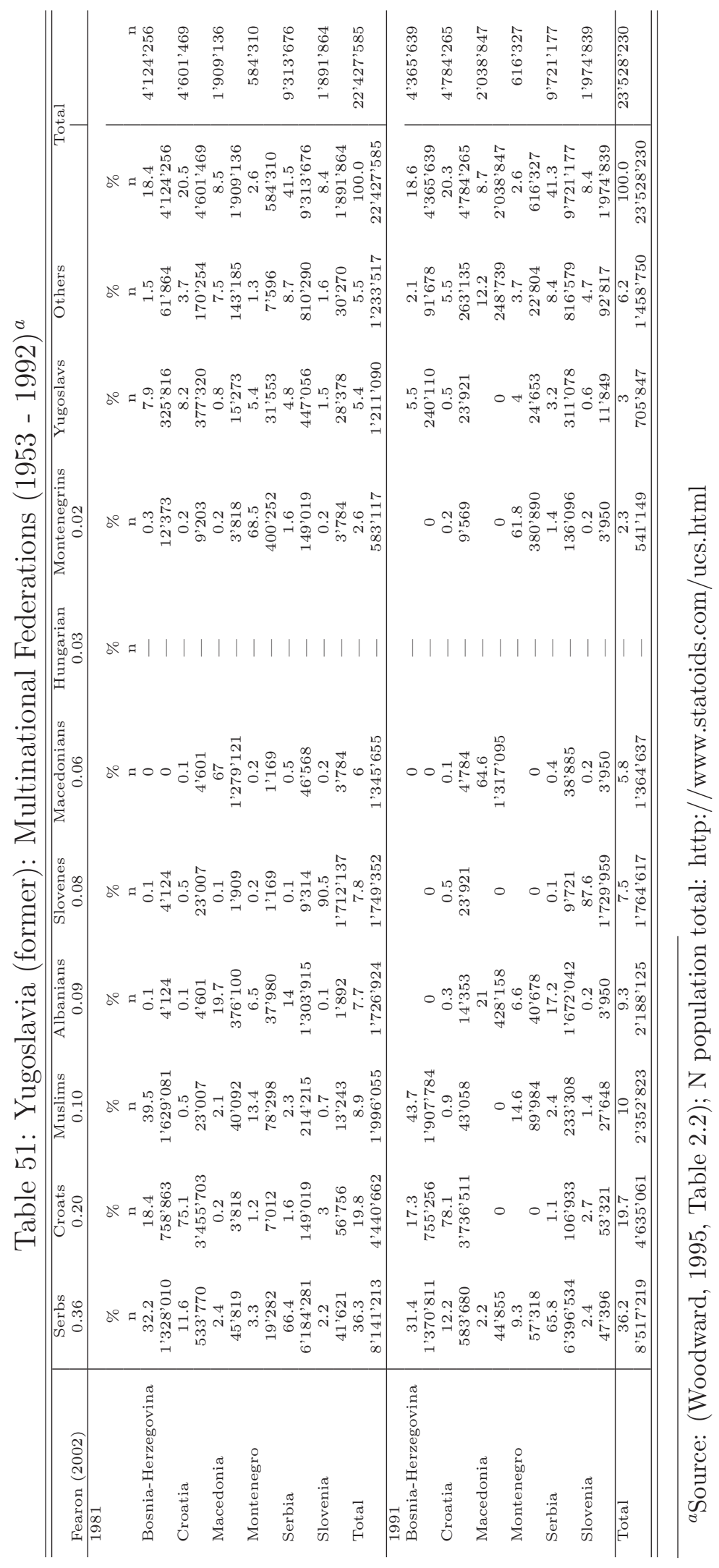




\section{Duration of federalism}

In the figures that follow (2-5) we depict how according to three measures federalism has changed over time for all countries that appear as having some decentralization according to at least one of the indicators. First, we use the Polity III indicator of "centralization of state authority: geographic concentration of decision making authority" with the following three values: $1=$ unitary, $2=$ intermediate category, 3 = federal. Second, we depict McGarry's (2002) classification with 0 indicating non-federal states, 1 national federations, and 2 multinational federations. Finally, we also report whether Henisz (2002) classifies a particular state in a particular year as federal, despite the fact that he focuses on fiscal federalism.

Beck, Clarke, Groff, Keefer and Walsh (2001) provide the following information on federalism:

\section{Federalism}

AUTON Are there contiguous autonomous regions?

Autonomous regions are not the same as states, provinces, etc. An autonomous region is recorded if a source explicitly mentions a region, area, or district that is autonomous or self-governing. We required that autonomous regions be contiguous with the country to which they belonged, on the presumption that such regions would be more likely to impose a check on central government decision making than would non-contiguous regions. Hence, the Basque region in Spain and Montenegro in Yugoslavia are counted as autonomous regions, but Northern Ireland, Hong Kong, Puerto Rico are not. Furthermore, they must be constitutionally designated as "autonomous" or "independent" or "special". Federal Districts or Capital Districts do not count as autonomous regions. Disputed autonomy is not recorded. Indian reservations are not counted as autonomous. Deviating from convention, no information recorded as 0 .

MUNI Are municipal governments locally elected?

0 if neither local executive nor local legislature are locally elected. 1 if the executive is appointed, but the legislature elected. 2 if they are both locally elected. No information, or no evidence of municipal governments, is recorded as blank. If one source has information on a specific period, and the other has no information on a different period, we do not extrapolate from one source to another - no information is always recorded as blank. If there are multiple levels of sub-national government, we consider the lowest level as the "municipal" level. For this variable, there was less information than usual, and as a result only 42 
STATE Are there state/province governments locally elected?

Recorded in the same manner as MUNI. If there are multiple levels of sub-national government, we consider the highest level as the "state/province" level. Indirectly elected state/province governments, where directly elected municipal bodies elect the state/province level, are not considered locally elected. Indirectly elected state/province governments elected by directly elected state/province bodies are considered locally elected. For this variable, there was less information than usual, and as a result only 66are non-blank.

AUTHOR Do the state/provinces have authority over taxing, spending, or legislating?

If 1 for any of these, category gets a 1. Authority over "cultural affairs", or "planning" in Communist systems, does not qualify. For this variable, there was less information than usual, and as a result only 38

STCONST Are the constituencies of the senators the states/provinces?

No information recorded as blank. If no senate or no states/provinces, NA. If the senate is only partially elected through the constituencies, we score according to how the majority is elected. If the senate is appointed or elected on a national basis, this gets a 0 .

¿From this data source we used the authority indicator, with 1 meaning that there is some authority devolved to subnational units, while 0 indicating the absence of such arrangements 


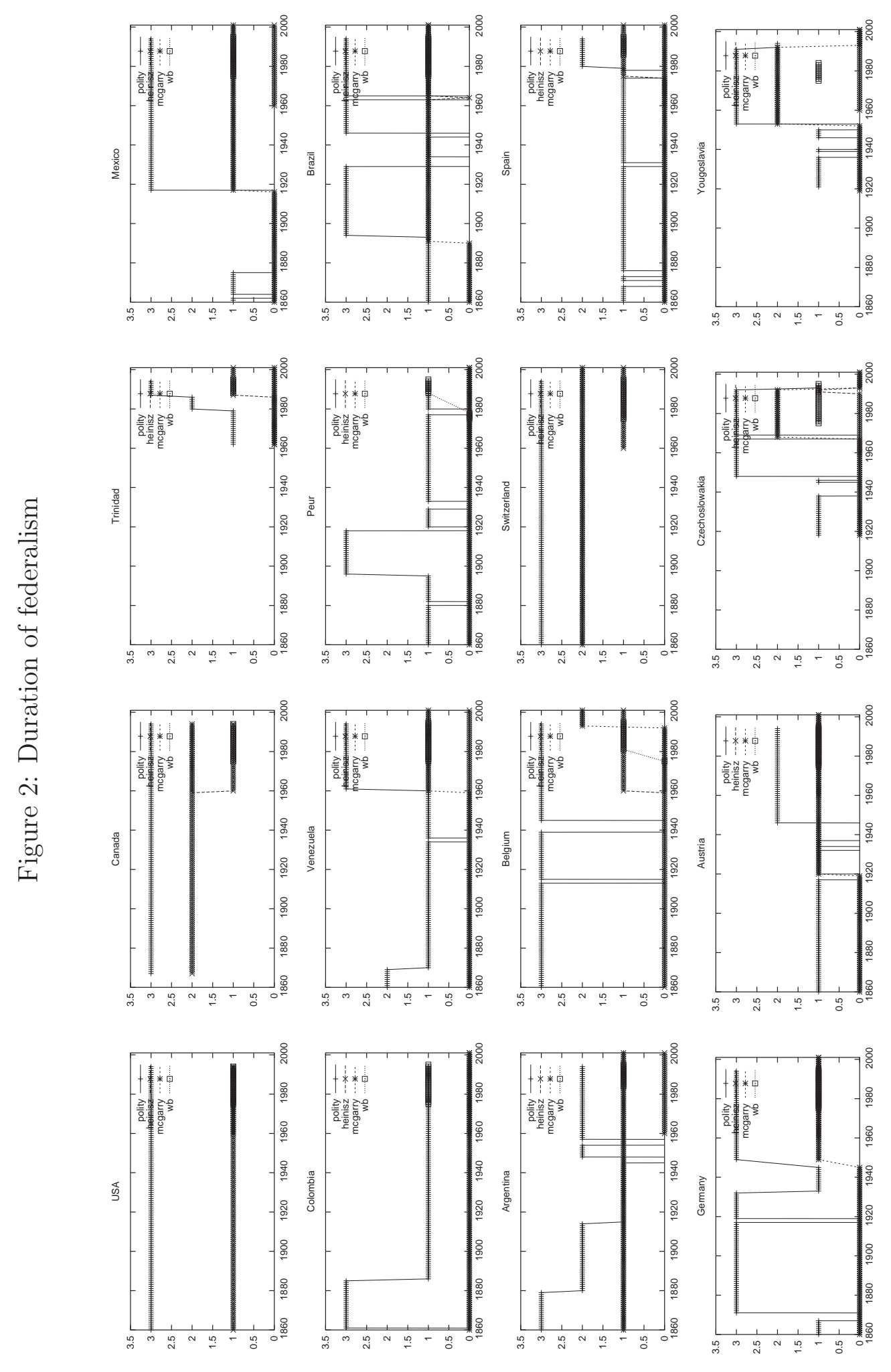




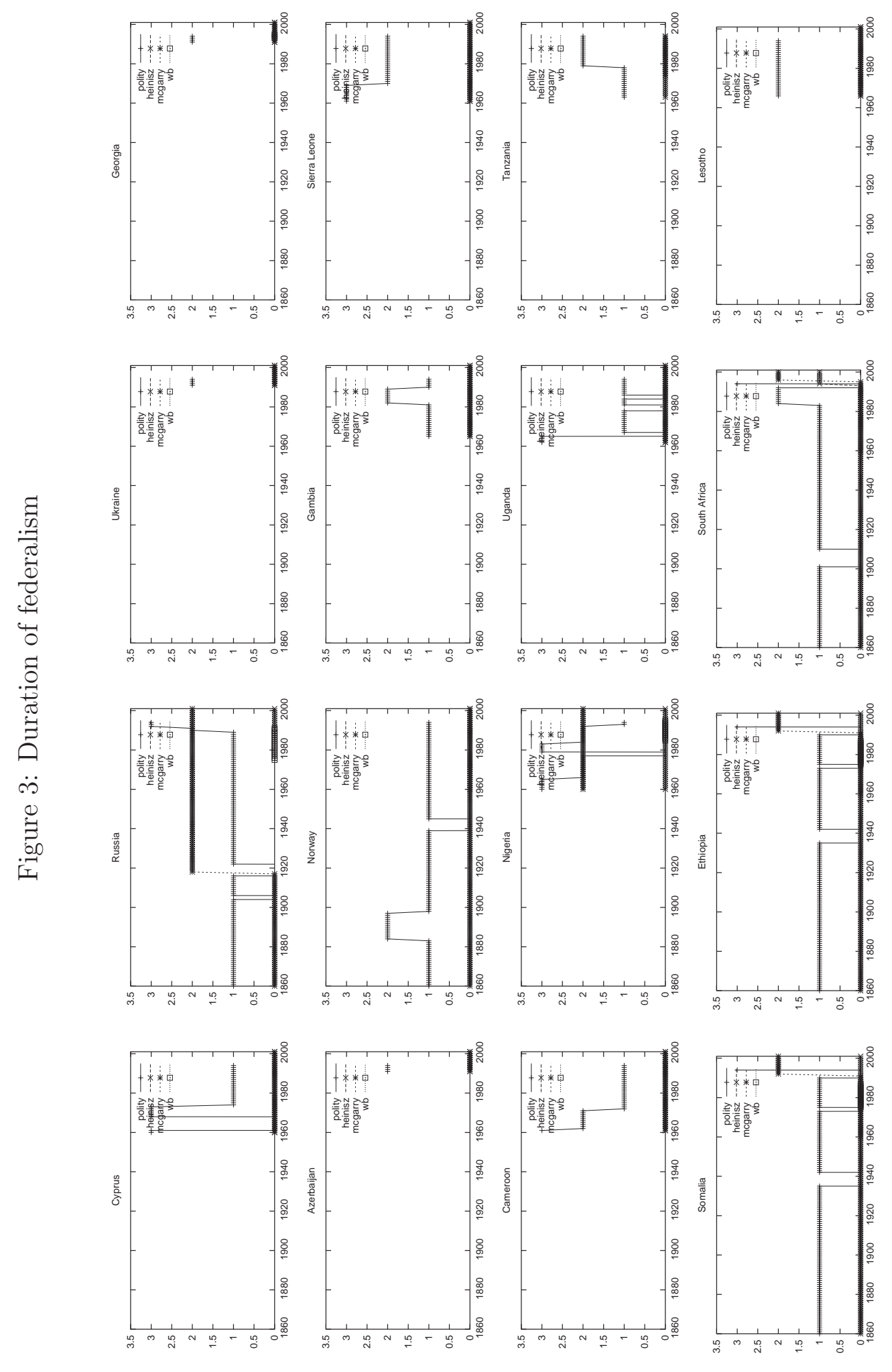




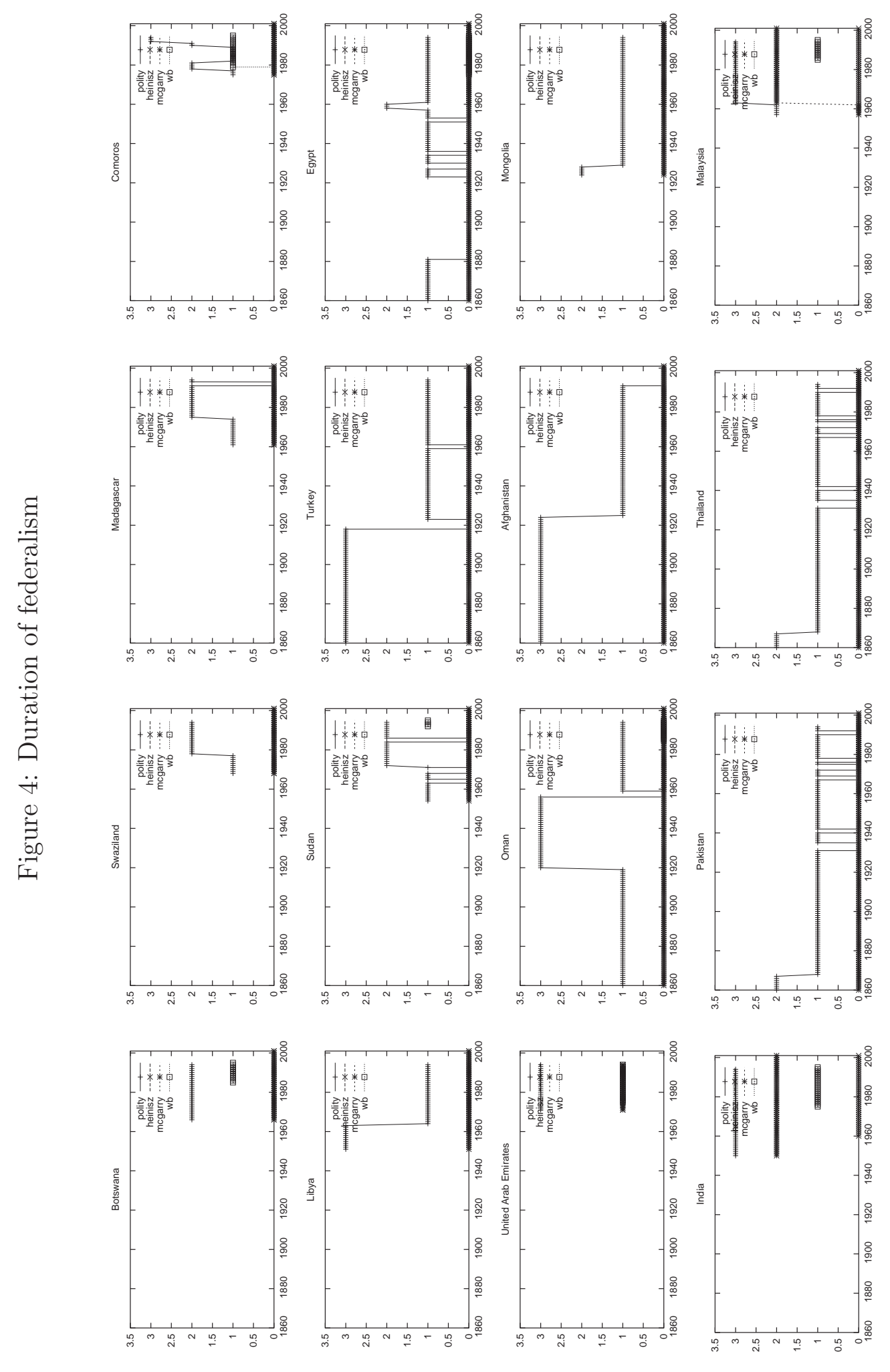



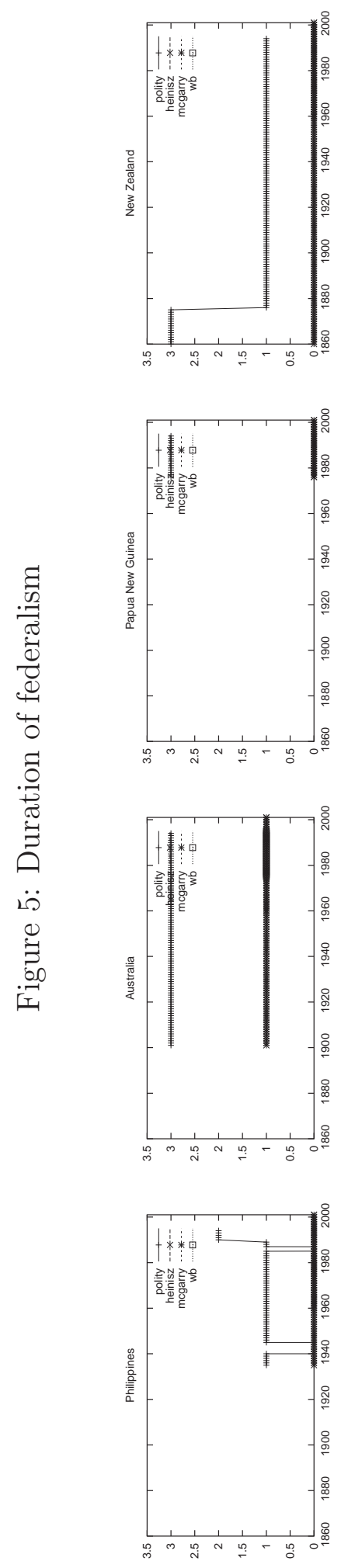


\section{References}

Acemoglu, Daron. 2005. "Constitutions, Politics and Economics: A Review Essay on Persson and Tabellini's "The Economic Effect of Constitutions"." Journal of Economic Literature 43(4):1025-1048.

Achen, Christopher. 2005. "Let's Put Garbage-Can Regressions and GarbageCan Probits Where They Belong." Conflict Management and Peace Science 22(4):327-339.

Alemán, Eduardo and Daniel Treisman. 2005. Fiscal Politics in "ethnically Mined," Developing, Federal States: Central Strategies and Secessionist Violence. In Sustainable Peace: Power and Democracy After Civil Wars, ed. Philip G. Roeder and Donald Rothchild. Ithaca: Cornell University Press pp. 173-216.

Alemika, Etannibi, Michael Bratton and Peter Lewis. 2001. "AFROBAROMETER: ROUND 1.5 SURVEY OF NIGERIA, 2001 [Computer File]. ICPSR04235-V1." Lagos, Nigeria: Research and Marketing Services (RMS) [producer], 2001. Ann Arbor, MI: Inter-university Consortium for Political and Social Research [distributor], 2005-11-22.

Alesina, Alberto and Enrico Spolaore. 2003. The Size of Nations. Cambridge: MIT Press.

Amoretti, Ugo M. and Nancy Bermeo, eds. 2003. Federalism and Territorial Cleavages. Johns Hopkins University Press.

Bakke, Kristin M. and Erik Wibbels. 2006. "'Peace-Preserving" Federalism?" Paper prepared for the 2006 Meeting of the International Studies Association, San Diego, CA.

Basanez, Miguel, Chappell Lawson, Roderic Camp, Wayne A. Cornelius, Jorge Dominguez, Frederico Estevez, Joseph Klesner, Beatriz Magaloni, James McCann, Alejandro Moreno, Pablo Paras and Alejandro Poire. 2004. "MEXICAN ELECTION PANEL STUDY, 2000 [Computer File]. ICPSR03380V1." Mexico City, Mexico: Reforma/Mexico City, Mexico: MORI [producers], 2001. Ann Arbor, MI: Inter-university Consortium for Political and Social Research [distributor], 2004.

Bauer, Otto. 1907. Die Nationalitätenfrage und die Sozialdemokratie. Wien: Verlag Ignaz Brand.

Beck, Thorsten, George Clarke, Alberto Groff, Philip Keefer and Patrick Walsh. 2001. "New Tools in Comparative Political Economy: The Database of Political Institutions." World Bank Economic Review 15(1):165-176.

Bednar, Jenna. 2006. "The Robust Federation." University of Michigan, Department of political science, book manuscript.

Besley, Timothy and Stephen Coate. 2003. "Centralized versus Decentralized Provision of Local Public Goods: A Political Economy Analysis." Journal of Public Economics 87(12):2611-2637. 
Bollen, Kenneth A., D.K. Guilkey and T.A. Mroz. 1995. "Binary Outcomes and Endogenous Explanatory Variables: Tests and Solutions with an Application to the Demand for Contraceptive Use in Tunisia." Demography 32.

Bolton, Patrick and Gérard Roland. 1997. "The Breakup of Nations: A Political Economy Analysis." The Quarterly Journal of Economics 112(4):1057-1090.

Bordignon, Massimo and Sandro Brusco. 2001. "Optimal Secession Rules." European Economic Review 45:1811-1834.

Brancati, Dawn. 2004. "Can Federalism Stabilize Iraq?" The Washington Quarterly 27(2):7-21.

Brancati, Dawn. 2006 (forthcoming). "Decentralization: Fueling the Fire or Dampening the Flames of Ethnic Conflict and Secessionism." International Organization .

Bratton, Michael, Massa Coulibaly and Fabiana Machado. 2003. "AFROBAROMETER: ROUND I SURVEY OF MALI, JANUARY 2000 [Computer File]. ICPSR03935-V1." Mali: African Workers Participation Development Program (PADEP) [producer], 2003. Ann Arbor, MI: Inter-university Consortium for Political and Social Research [distributor], 2004.

Breton, Albert. 1964. "The Economics of Nationalism." Journal of Political Economy $72(4): 376-386$.

Bruk, Salomon I. 1964. Atlas Narodov Mira. Moscow: Academy of Science USSR.

Bunce, Valerie. 2003a. "Cooperation, Compromise, or Conflict: Three Models of Center-Regional Bargaining in Ethnofederal States." Paper presented at the annual meeting of the American Political Science Association Philadelphia Mariott Hotel, Philadelphia, PA, 2003-08-27 2003-09-05.

Bunce, Valerie. 2003b. "Rethinking Recent Democratization: Lessons from the Postcommunist Experience." World Politics 55(2):167-192.

Cederman, Lars-Erik, Jan Ketil Roed and Nils Weidmann. 2006. "Georeferencing of Ethnic Groups. Creating a New Dataset." PRIO GROWnet Workshop, Oslo.

Christin, Thomas and Simon Hug. 2003. "Federalism and Conflict Resolution: Considering Selection Biases." Paper prepared for presentation at the Midwest Political Science Association Annual Meeting, April 3-6 Chicago.

Christin, Thomas and Simon Hug. 2004. "Methodological Issues in Studies of Conflict Processes." Prepared for delivery at the 2004 Annual Meeting of the American Political Science Association, Chicago, September 2 - September $5,2004$.

Christin, Thomas and Simon Hug. 2006. "Political Institutions and Ethnic Conflict Resolution: Dealing with the Endogenous Nature of Institutions." Paper prepared for the 2006 Meeting of the International Studies Association, San Diego, CA. 
Clarke, Kevin. 2005. "The Phantom Menace: Omitted Variable Bias in Econometric Research." Conflict Management and Peace Science 22(4):341-352.

Cohen, Frank S. 1997. "Proportional Versus Majoritarian Ethnic Conflict Management in Democracies." Comparative Political Studies 30(5):607-630.

Congleton, Roger D. 2000. A Political Efficiency Case for Federalism in Multinational States: Controlling Ethnic Rent-Seeking. In Competition and Structure: The Political Economy of Collective Decisions: Essays in Honor of Albert Breton, ed. G. Galeotti, P. Slamon and R. Wintrobe. New York: Cambridge University Press pp. 365-397.

Cornell, Svante E. 2002. "Autonomy as a Source of Conflict Caucasian Conflicts in Theoretical Perspective." World Politics 54(2):245-276.

Elkins, Zachary and John Sides. 2006. "The Problem of Stateness." Paper prepared for the 2006 Meeting of the International Studies Association, San Diego, CA.

European Values Study Group and World Values Survey Association. 2006. "EUROPEAN AND WORLD VALUES SURVEYS FOUR-WAVE INTEGRATED DATA FILE, 1981-2004, V.20060423, 2006. Aggregate File." Producers: Análisis Sociológicos Económicos y Políticos (ASEP) and JD Systems (JDS), Madrid, Spain/Tilburg University, Tilburg, The Netherlands. Data Files Suppliers: Analisis Sociologicos Economicos y Politicos (ASEP) and JD Systems (JDS), Madrid, Spain/Tillburg University, Tillburg, The Netherlands/ Zentralarchiv fur Empirische Sozialforschung (ZA), Cologne, Germany:) Aggregate File Distributors: Análisis Sociológicos Económicos y Políticos (ASEP) and JD Systems (JDS), Madrid, Spain/Tillburg University, Tilburg, The Netherlands/Zentralarchiv fur Empirische Sozialforschung (ZA) Cologne, Germany.

Fearon, James D. 2002. Ethnic Structure and Cultural Diversity around the World: A Cross-National Data Set on Ethnic Groups. Boston: Paper prepared for delivery at the 2002 Annual Meeting of the American Political Science Association, Boston, August 29-September 1, 2002.

Fearon, James D. and David D. Laitin. 2000a. "Development of Group Concentration Values for the MAR Data Set." Prepared for presentation at the second semi-annual LiCEP meeting, to be held at the University of Pennsylvania, October 20-22, 2000.

Fearon, James D. and David D. Laitin. 2000b. "Violence and the Social Construction of Ethnic Identity." International Organization 54(4 Autumn):845-877.

Fearon, James D. and David D. Laitin. 2003. "Ethnicity, Insurgency, and Civil War." American Political Science Review 97(1):1-17.

Filippov, Mikhail, Peter Ordeshook and Olga Shvetsova. 2004. Designing Federalism: A Theory of Self-Sustainable Federal Institutions. Cambridge: Cambridge University Press. 
Ghai, Yash. 2002. Constitutional Asymmetries: Communal Representation, Federalism, and Cultural Autonomy. In The Architecture of Democracy: Institutional Design, Conflict Management, and Democracy in the Late Twentieth Century, ed. Andrew Reynolds. Oxford: Oxford University Press pp. 141170 .

Ghai, Yash P., ed. 2000. Autonomy and Ethnicity: Negotiating Competing Claims in Multi-Ethnic States. Cambridge: Cambridge University Press.

Glazer, Nathan. 1983. Federalism and Ethnicity: The American Solution. In Ethnic Dilemmas 1964-82, ed. Nathan Glazer. Cambridge: Harvard University Press pp. 274-292.

Goertz, Gary. 2006. Social Science Concepts: A User's Guide. Princeton: Princeton University Press.

Griffiths, Ann L. and Karl Nerenberg, eds. 2005. Handbook of Federal Countries. Montreal: McGill-Queen's University Press.

Gurr, Ted Robert. 1993. Minorities at Risk. A Global View of Ethnopolitical Conflict. Washington: United States Institute of Peace Press.

Gurr, Ted Robert. 2000. "Ethnic Warfare on the Wane." Foreign Affairs 79(3):5265.

Hale, Henry E. 2004. "Divided We Stand: Institutional Sources of Ethnofederal State Survival and Collapse." World Politics 56(1):165-193.

Hale, Henry E. 2006. "Designing Ethnofederalism for Divided Societies: Developments in the USSR and Russia." Perspectives on Politics .

Hausman, Jerry. 1978. "Specification Tests in Econometrics." Econometrica 46(6):1251-1271.

Henisz, Witold J. 2002. "The Institutional Environment for Infrastructure Investment." Industrial and Corporate Change 11(2).

Hug, Simon. 2005a. "The Effect of Misclassifications in Probit Models. Monte Carlo Simulations and Applications." Zürich: unpublished paper, IPZ, Universtität Zürich.

Hug, Simon. 2005b. "Federal Stability in Unequal Societies." Constitutional Political Economy 16(2):149-160.

Jaggers, Keith and Ted Robert Gurr. 1995. "Tracking Democracy's Third Wave with Polity III Data." Journal of Peace Research 32(4):469-482.

Kohli, Atul. 2004. India: Federlism and the Accommodation of Ethnic Nationalism. In Federalism and Territorial Cleavages, ed. Ugo M. Amoretti and Nancy Bermeo. Baltimore: The Johns Hopkins University Press chapter 10, pp. 281-300. 
Lake, David A. and Donald Rothchild. 2005. Territorial Decentralization and Civil War Settlements. In Sustainable Peace : Power and Democracy After Civil Wars, ed. Philip G. Roeder and Donald Rothchild. Ithaca: Cornell University Press pp. 109-132.

Lemco, Jonathan. 1991. Political Stability in Federal Governments. New York: Praeger.

Lipset, Seymour M. 1963. Political Man. Garden City: Anchor Books.

Mansfield, Edward D. and Jack Snyder. 2005. Electing to Fight. Why Emerging Democracies Go to War. Cambridge: MIT Press.

McGarry, John. 2002. "Federalism (Federation) as a Method of Ethnic Conflict Regulation." Working paper to be presented at the Conference on From Power-sharing to Democracy: Post- Conflict Institutions in Ethnically Divided Societies, London, Ontario, November 9-10 2002.

McGarry, John and Brendan OLeary. 2005. Federation as a Method of Ethnic Conflict Regulation. In From Power Sharing to Democracy, ed. Sid Noel. Montreal: McGill-Queen's University Press.

Myerson, Roger B. 2006. "Federalism and Incentives for Success of Democracy." Quarterly Journal of Political Science 1:3-23.

Nordlinger, Eric A. 1972. Conflict Regulation in Divided Societies. Cambridge: Center for International Affairs, Harvard University.

Panizza, Ugo. 1999. "On the Determinants of Fiscal Centralization: Theory and Evidence." Journal of Public Economics 74(1):97-139.

Rabushka, Alvin and Kenneth A. Shepsle. 1972. Politics in Plural Societies: A Theory of Democratic Instability. Columbus: C.E. Merrill.

Riker, William H. 1964. Federalism: Origin, Operation, Significance. Boston: Little, Brown.

Rivers, Douglas and Quang H. Vuong. 1988. "Limited Information Estimators and Exogeneity Tests for Simultaneous Probit Models." Journal of Econometrics 39(3 NOV):347-366.

Roeder, Philip G. 1991. "Soviet Federalism and Ethnic Mobilization." World Politics 43(2):196-232.

Saideman, Stephen M. 1998. Is Pandora's Box Half Empty or Half Full? The Limited Virulence of Secessionism and the Domestic Sources of Disintegration. In The International Spread of Ethnic Conflict. Fear, Diffusion, and Escalation, ed. David A. Lake and Donald S. Rothchild. Princeton: Princeton University Press pp. 127-150.

Saideman, Stephen M., David J. Lanoue, Campenni Michael and Samuel Stanton. 2002. "Democratization, Political Institutions, and Ethnic Conflict: A Pooled Time-Series Analysis, 1985-1998." Comparative Political Studies 35(1, February):103-129. 
Saideman, Stephen M. and R. William Ayres. 2000. "Determining the Causes of Irredentism: Logit Analyses of Minorities at Risk Data from the 1980s and 1990s." Journal of Politics 62(4 (Nov)):1126-1145.

Sambanis, Nicholas. 2005. "Globalization, Decentralization, and Secession: A Review of the Literature and Some Conjectures." New Haven: Yale University, Departement of Political Science.

Sambanis, Nicholas and Branko Milanovic. 2004. "Explaining the Demand for Sovereignty." New Haven: Yale University, Departement of Political Science.

Schou, Arild and Marit Haug. 2005. "Decentralisation in Conflict and PostConflict Situations." NIBR Working Paper: 2005:139.

Snyder, Jack. 2000. From Voting to Violence: Democratization and Nationalist Conflict. New York: Norton.

Stepan, Alfred. 1999. "Federalism and Democracy: Beyond the U.S. Model." Journal of Democracy 10(4):19-34.

Tir, Jaroslav. 2005. "Keeping the Peace After Secession: Territorial Conflicts Between Rump and Secessionist States." Journal of Conflict Resolution 49(5):713-741.

Toft, Monica Duffy. 2003. The Geography of Ethnic Violence: Identity, Interests, and the Indivisibility of Territory. Princeton: Princeton University Press.

University of Tokyo Institute of Oriental Culture. 2003. "ASIABAROMETER, 2003 [Computer File]. ICPSR04300-V1." Tokyo: University of Tokyo, Institute of Oriental Culture [producer], 2003. Ann Arbor, MI: Inter-university Consortium for Political and Social Research [distributor], 2005-11-04.

Watts, Richard J. 1996. Schweizerische Identität und der Schweizerische Beitrag an Europa: Aus der Sicht Eines Ausländers. In Schweizer Eigenart - eigenartige Schweiz, ed. Wolf Linder, Prisca Lanfranchini and Ewald R. Weibel. Bern: Haupt pp. 129-142.

Watts, Ronald L. 1998. "Federalism, Federal Political Systems, and Federations." Annual Review of Political Science 1:117-137.

Woodward, Susan L. 1995. Balkan Tragedy: Chaos and Dissolution After the Cold War. Washington, D.C.: Brookings Institution.

Young, Robert. 1998. Games of Secession. In The New Palgrave Dictionary of Economics and the Law, ed. Peter Newman. London: Macmillan Reference pp. 183-188. 